\title{
The locust problem in Afghanistan and experiments with low-dosage spraying.
}

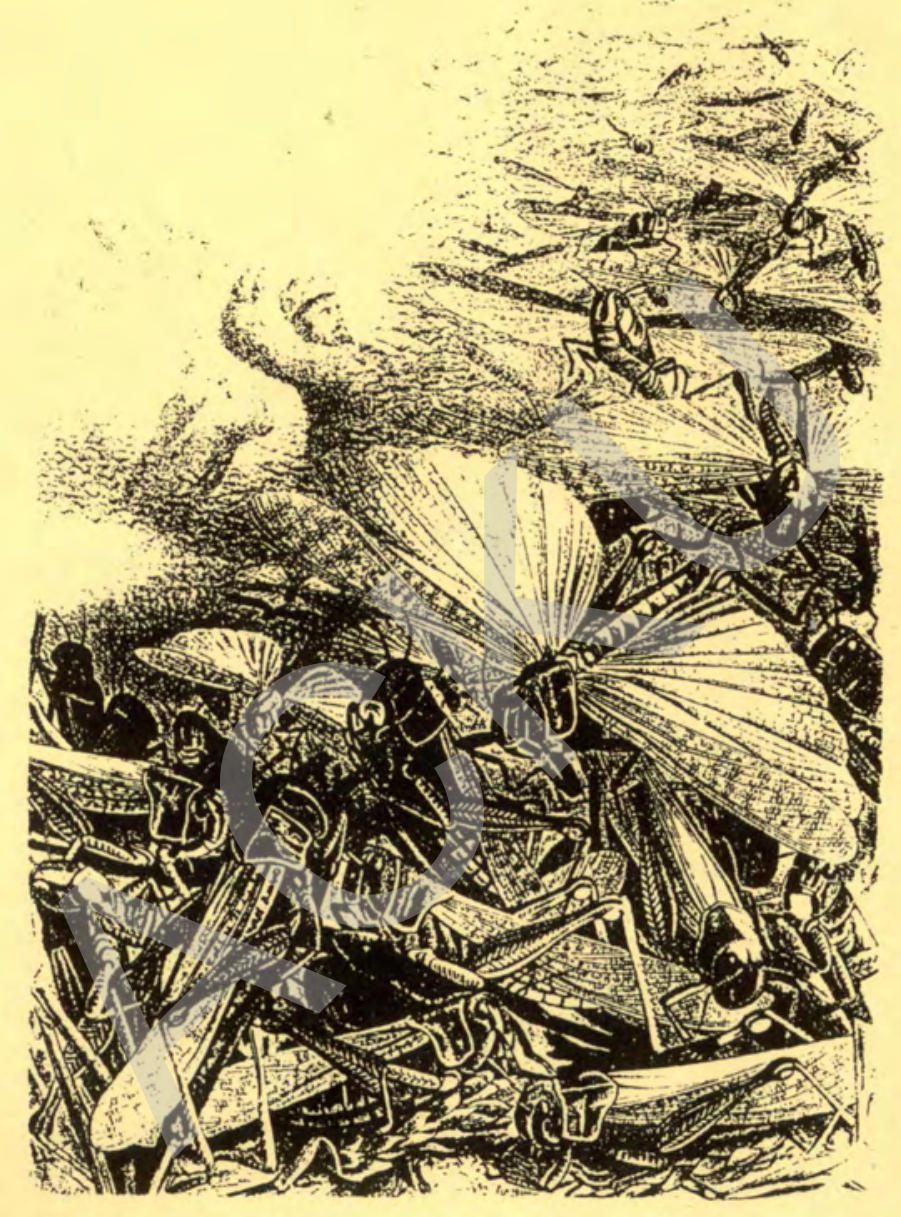

Key words: Badakshan, Afghanistan, locusts, Schistocerca gregaria, Dociostaurus marroccanus, Calliptamus italicus, pesticides, Deltamethrin (= Decis) , Benzene-hexa-chloride (=BHC), toxicology, biological control.

\section{Cand. Agric. thesis}

by

\section{Sølve D. Sondbø}

Department for Biology and Natur Conservation

The Agricultural University of Norway

Ås, May 1992. 
Author's adress :

Sølve Sondbø

Stigervn. 61

$\mathrm{N}-3200$ SANDEFJORD

NORWAY 


\section{Table of contents}

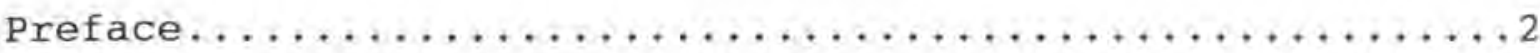

1.1 Sammendrag (Norwegian summary) $\ldots \ldots \ldots \ldots \ldots \ldots \ldots$

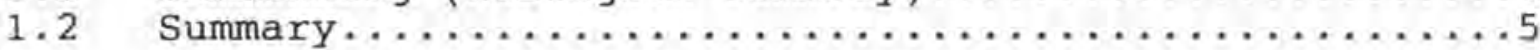

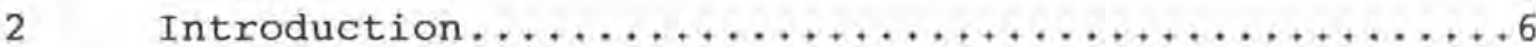

3 Locust biology

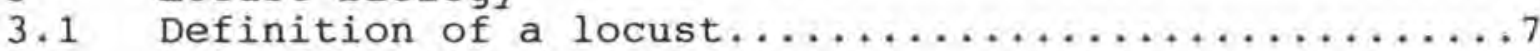

3.2 Classification and species $\ldots \ldots \ldots \ldots \ldots \ldots \ldots$

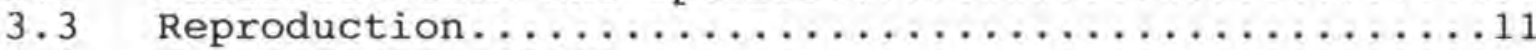

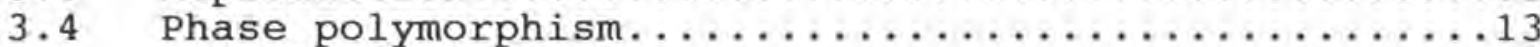

3.5 Population dynamics....................

4 Locusts in Afghanistan

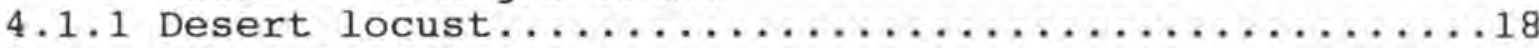

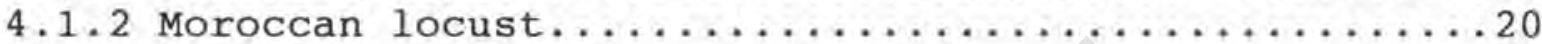

4.1 .3 Italian locust. . . . . . . . . . . . . . . . . 22

4.2 Locust damage and food situation..............

5 Experiments with low dosages of the pesticides Deltameth rin (Decis) and Benzene-hexa-cloride (BHC) on the

Moroccan locust, in Badakshan, Afghanistan, 1991. (By

Ottesen, P.S., Sondbø, S. \& Khan, Z.)

5.1 Material and methods

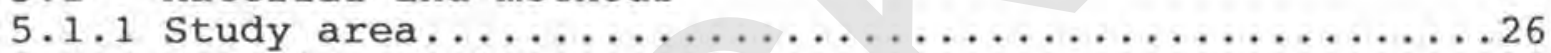

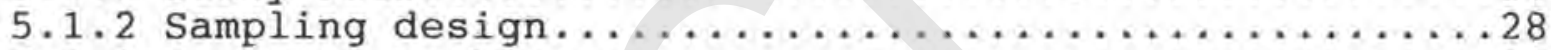

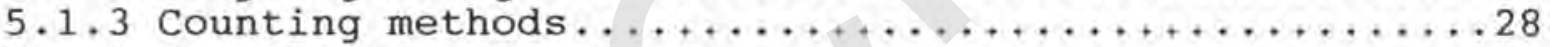

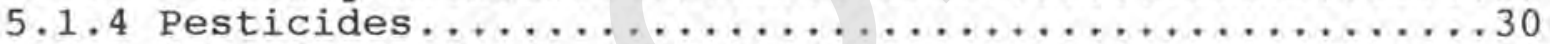

5.1 .5 Spraying and dusting techique..............

5.2 Results

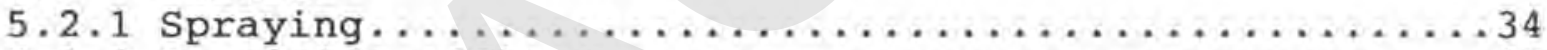

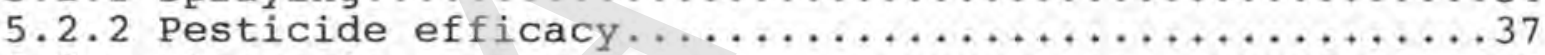

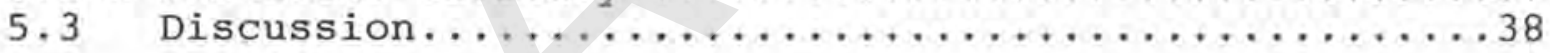

6 Toxicology of Decis and BHC

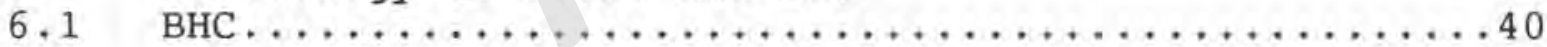

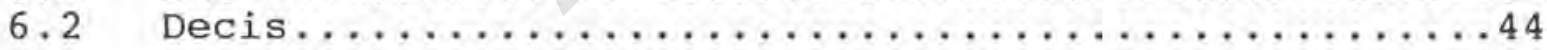

7 Prospects of biological control

7.1 The need for biological control $\ldots \ldots \ldots \ldots \ldots \ldots \ldots \ldots 4$

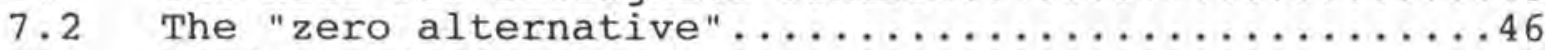

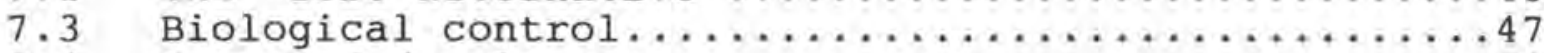

7.4 State of development..................

8 Recommendations for the NCA project

8.1 General advice........................ 51

8.2 Type of pesticide.............

8.3 Cost-analysis of different concentrations and mixing with vegetable oil ...................... 52

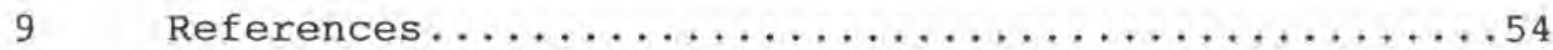

Appendix Raw data for the low dosages experiments 


\section{Preface}

This report is the thesis for the Cand. Agric. (M. Sc) degree at the Agricultural University of Norway, and ends a five-year study in management of natural resources.

The field work was conducted in Badakshan, Afghanistan during the summer of 1991.

\section{Acknowledgements}

Many persons have been very helpful during the preparations and work with this study, and I would like to thank them all.

This study was done in cooperation with the Norwegian Committee for Afghanistan (NCA), and we would like in particular to thank the director of the Peshawar office, Kristian Berg for valuable coordination of this Badakshan expedition and his always helping hand with all arrangements; thanks to Siri Caspersen, Kristine Naterstad, Bjørn Rakstang, Hans Husum and Jan Reynolds in the NCA for valuable help; Per Hornfelt for leading us safely from Peshawar through the Hindukush mountains to Keshim and for his good companionship during the strenious journey; translators Ahmad Hussein and Dr. Hasibullah and many other NCA personnel, too many to mention, for practical advice and good friendship.

Thanks Said Jamaluddin, the Keshim Valley representative in Peshawar, for inviting us to Keshim and supplying guards for the journey, for helping us in Pakistan, and his family in Keshim for food and lodging. Several Afghan commanders helped us along the way, and we would like to thank the following in the order we met them (names, village/city):

Sulmai Khan, Jurm; Mulla Abdull Azis, Nawabud, Daraim; Mullah Said Amir, Daraim; Khairuddin, Teshkan; Babajan, Arkhash; Abdulrab, Karasti; Rezai, Drajim; Amir Barad Khan Tadbeer, Keshim valley and Arian Poor, Jamiate leader of Badakshan.

The NCA locust teams in Jurm and Keshim followed us in the field during the study, and we would in Particular thank the supervisors Abdulla (Jurm) and Fazle-e-Khada (Keshim). The following field workers helped us in the field: Pir Mohammad, Abdul Basir, Ghulam Mohammad and Rak Mullah.

In Peshawar we got valuable information from Azam Gul, The Swedish Committee for Afghanistan (SCA); Bob Eaton, program manager in United Nations Development Program (UNDP); Marc Witton and Don Meyer, SCA. Thanks to Tore Schanke (Landbrukdepartementes Giftnemd) and Jannicke Utne Skårer (Norges Vetrinær Høyskole) for information on toxicoly, and to Tore Erlandsen (Collett Kjemi) for help with contacting Roussel Uclaf, France.

Thanks to Noragric, the Agricultural University of Norway, for financial support, and to NCA, receiving funds from the Royal Norwegian Ministry for Foreign Affairs and United Nations Development Program (UNDP) for financing the journey from Peshawar to Keshim and return. Thanks also to Ann-Toril Dovre, the Norwegian Embassy, Islamabad. 
I am particularly indepted to entomologist Preben Ottesen, who inspired me to study the locusts problem and was a good friend during the field work in Afghanistan. I will also thank my father Dag Sondbø and my brother Sverre Sondbø for reading through a draft version of this thesis and correcting my English. 


\subsection{Sammendrag}

Tre vandregresshopper forekommer i Afghanistan; ørkenvandregresshoppe (Scistocerca gregaria), marokansk vandregresshoppe (Dociostaurus maroccanus) og italiensk vandregresshoppe (Calliptamus italicus). Skadene de gjør varierer fra år till år. Afghanistan er normalt ikke blant landene som rammes sterkest av vandregresshopper. Likevel kan skadene på avlinger bli store regionalt i enkelte år, og lokalt i øvrige år. Særlig i provinsene som allerede i utgangspunktet har lite mat (negativ matbalanse) kan vandregresshoppene forårsake sult. Borgerkrigen i Afghanistan har gitt en økning i tilgjenglige habitater for vandregresshoppene, da mye jord har blitt liggende brakk. Samtidig er den intense bekjempningen russerne finansierte redusert.

Ulike doser av pyretroidet deltametrin (=Decis) og det klorerte hydrokarbonet BHC ble testet mot marokansk vandregresshoppe. Forsøkene ble utført i Keshim-dalen i provinsen Badakshan i nordøst Afghanistan i juni 1991. Det anbefales at den tidligere anbefalte dosen på $12.5 \mathrm{~g} \mathrm{a.i./ha} \mathrm{(gram} \mathrm{aktivt} \mathrm{stoff} \mathrm{per} \mathrm{hektar)} \mathrm{reduseres} \mathrm{til} 3 \mathrm{~g} \mathrm{a}$.i./ha da denne siste dosen reduserte gresshoppene med mer enn $96 \%$. Denne dosen er bare $1 / 4$ til $1 / 5$ av anbefalt dose fra produsenten, og 1/7 av hva den pakistanske selgeren anbefalte.

Eksperimentene med BHC gir ikke grunnlag for at den brukte dosen $2.4 \mathrm{~kg}$ a.i./ha kan reduseres.

BHC må sies å være miljømessig uakseptabel på grunn av høy akutt giftighet for vannorganismer og pattedyr, kombinert med langsom nedbrytning og bioakkumulerbarhet. Deltametrin har langt færre miljømessige sideeffekter og er effektiv mot gresshoppene. På dette grunnlag anbefaler jeg NCA fortsatt å bruke deltametrin i gresshoppeprosjektet.

Transportutgifter og kjemikaliekostnader kan reduseres ved å kjøpe Decis i en mer konsentrert form som $2.5 \%$ istenfor dagens benyttede $0.5 \%$. Den mer konsentrerte formuleringen bør blandes med en vegetabilsk olje som sennepsfrøolje inne i Afghanistan. Sennepsfrøolje kan skaffes lokalt i Afghanistan, og produseres blant annet i Keshim-dalen.

Observasjonene av gresshoppe-bekjempelsen i 1991, viser at kurset medarbeiderne i prosjektet gjennomgår bør bli noe mer praktisk rettet, med felttester, praktiske beregninger og bedre trening i systematikk.

Jeg anbefaler også Afghanistankomiteen å foreta vurderinger over det såkalte "nullalternativet". Muligens kan det være mer kostnadseffektivt å gi mathjelp til bønder som rammes av vandregresshopper eller finansiere en slags forsikringsordning framfor å sprøyte mot gresshoppene. I løpet av noen år bør dessuten biologisk kontroll av gresshopper være tilstrekkelig utviklet til å kunne erstatte kjemisk bekjempelse. 


\subsection{Summary}

Three locust species occur in Afghanistan; Desert locust (Schistocerca gregaria), Italian locust (Calliptamus italicus) and Moroccan locust (Dociostaurus maroccanus). The damage they do vary from year to year. Afghanistan is normally not among the countries worst affected by locusts. However, locusts may in some years or locally cause important crop losses. Especially in areas that already have a bad food balance, this may cause hunger.

Various dosages of the pyrethroid deltamethrin (=Decis) and the clorated hydrocarbon BHC has been tested against the Maroccan locust in the Keshim Valley in Badakshan, Afghanistan during June 1991. It is recommended that the previously suggested deltamethrin dosage of $12.5 \mathrm{~g}$ a.i./ha is reduced to $3 \mathrm{~g} \mathrm{a.i./ha}$, as the latter give a reduction in locusts numbers of more than $96 \%$. Experiments with BHC showed that at present, the recommended dosage of $2.4 \mathrm{~kg}$ a.i./ha should be maintained.

$\mathrm{BHC}$ is not acceptable from an environmental viewpoint because of high acute toxicity to aquatic life and mammals, persistence in the environment and bioaccumulation. I recomend deltamethrin to be used in the locust program, because of less environmental side-effects combined with high efficiency against locusts.

Money can be saved in the locust program if a higher formulation of deltametrin e.g. $2.5 \%$ is bought instead of $0.5 \%$, and then mixed inside Afghanistan with a vegetable oil like mustard seed oil. I also recomend NCA to follow the development in biological control as an alternative to chemical insecticides.

Some observations of insufficient training of the field staff in the spraying campaign is mentioned at the end of this report, with suggestions for future improvements. 


\section{Introduction}

Locust have historically been a problem in Afghanistan. Before the war the Moroccan locust was extensively controlled with support from the Soviet Union. The war caused vegetation changes favouring the locust, and the population increased. During the late summer of 1988 it became evident that several provinces in Northern Afghanistan experienced pest problems.

In cooperation with several non-governmental organisations (NGO's) the UN Food and Agriculture Organization (FAO) and United Nations Development Program (UNDP) initiated a control program for the Moroccan locust and the Sunn pest. Training of Afghan personnel was started in Peshawar, Pakistan 1990 and field work was planned to start during early spring 1991. The Norwegian Committe for Afghanistan (NCA) was given responsibility for the control program in the north-easternmost province of Afghanistan; Badakshan. According to The Swedish Committee for Afghanistan (1990 a) Badakshan had a high infestation of adult locusts and their young hoppers, which resulted in estimated yield losses of 56 and $57 \%$ respectively.

While pesticides supplied through the UN was to be transported through government controlled areas of Afghanistan, the NCA decided to buy and transport pesticides from Pakistan to Badakshan. Problems arose during transport of the UN supplied pesticide, Sumicombi (fenitrothion + a pyrethroid). The chlorated hydrocarbon BHC which is banned in many western countries, but stored in huge amounts in Afghanistan ( 8000 tons stored, Azam Gul, Agricultural director of SCA, pers. comm.) probably had to be used.

In the autumn of $1990, \mathrm{Mr}$. Ottesen was contacted by the Norwegian Committee for Afghanistan (NCA) who asked for advice on pesticides and dosages for the control program. A list of pesticides known to be effective against locust and available for purchase in Pakistan at that time was presented. It was advised that the NCA used Desic for their 1991 locust campaign. 7150 liters of $0.5 \%$ Decis, ULV formulation, was bought in Pakistan and transported to the cities of Jurm and Keshim in Badakshan. Included in the transport was 60 handsprayers of the brand Micro ULVA and batteries. The equipment arrived in 1990 before the snow closed the passes. The pesticides and sprayers were thus ready for use during the spring of 1991.

The present study was initiated to find the minimum dosage of Decis that would be effective to control the Moroccan locust. In this way the spraying will be as environmentally safe as possible, and economically as cheap as possible. Because of the large stocks, BHC probably will be used for years to come in Afghanistan. It was therefor decided to test minimum dosage also for this pesticide.

Large reductions in pesticide use have been achieved in other studies (e.g. Ottesen \& Sømme 1987, Ottesen et al. 1989, Ottesen \& Sømme 1990, Ottesen et al. 1990) by mixing the pesticides with vegetable oil and by carefully monitoring the ULV spraying techinque. These projects and the present one have been financed by the Royal Norwegian Ministry of Foreign Affairs, and have resulted in great economical savings for the spraying campaigns financed by Norway. 


\section{3: Locust biology}

\subsection{Definition of locusts}

The major source of the following is Chapman (1976):

Locusts look just like grasshoppers and are not morphologically distinguishable from them. They differ only in their behaviour. Locusts present in large numbers become gregarious. They tend to be attracted to each other and group together. Grasshoppers will remain dispersed through the environment, and no more grouping occurs than would be espected in a random distribution.

The second major distinguishing feature of locusts is that they migrate during daytime in swarm containing many million of individuals. Migration itself is not a pecularity of locusts because there is an increasing amount of evidence that also grasshoppers migrate, but only as isolated individuals and at night. However, extensive dayflights have been recorded for the grasshoppers Melanoplus sanguinipes and Aiolopus savigny, which occasionally form swarms.

Locusts do not always occur in migrating aggregations; at lower densities they also exist as solitary individuals. In this phase they show no tendency to aggregate when put together in a crowd. We are forced to conclude that even on behavioral ground there is no clearcut distinction between locust and grasshoppers. Rather we must think of them as forming a series, from grasshoppers which never aggregate to locusts which very commonly do so. In between is a range of species which sometimes aggragate, but sometimes do not. If they do so fairly commonly we regard them as locusts. If they aggregate only occasionally we think of them as grasshoppers. 


\subsection{Classifification and species.}

The main features of the body are shown in Fig. 1.

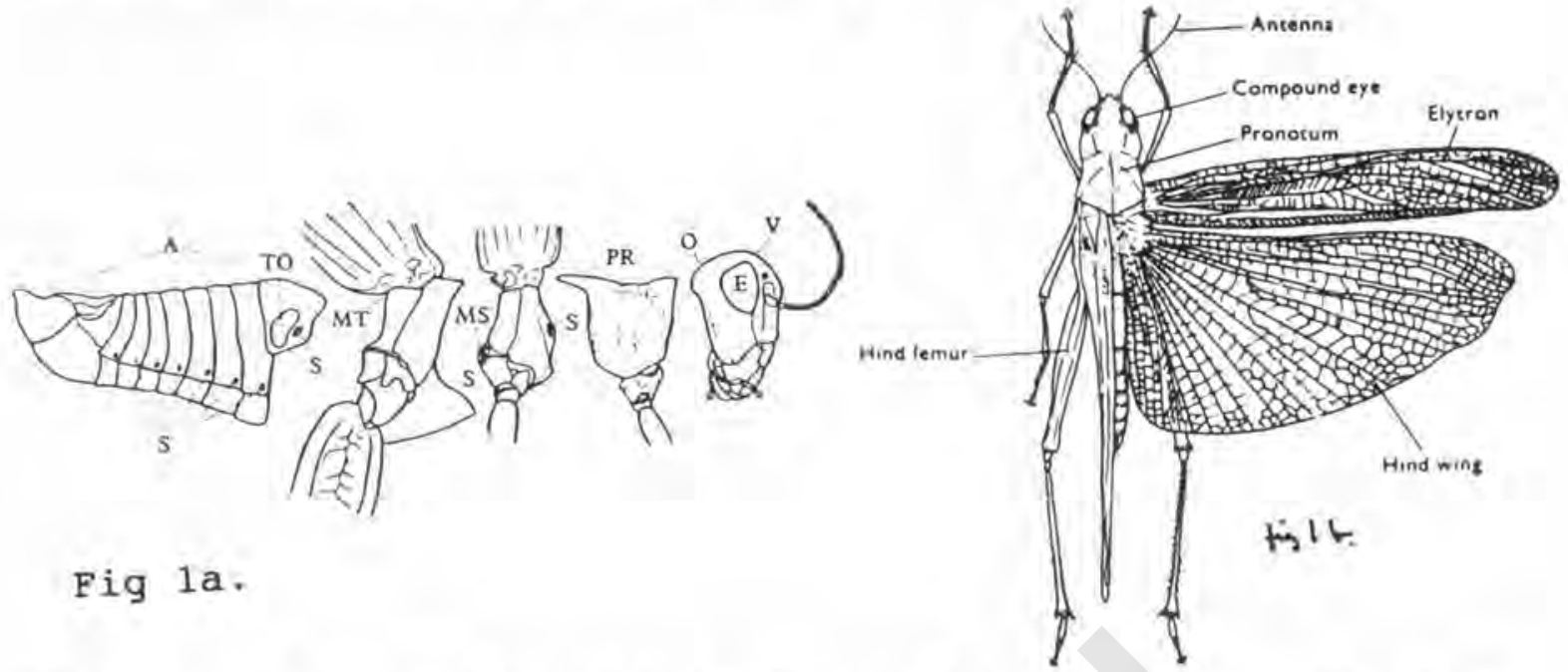

Fig 1a. Main features of acridoid body. $V=$ vertex, $O=$ occiput, $E=$ compound eye, $\mathrm{PR}=$ prothorax, $\mathrm{MS}=$ mesothorax, $\mathrm{MT}=$ metathorax, $\mathrm{S}=$ spiracle, $\mathrm{A}=$ abdomen, TO=tymphanal organ (Uvarov 1928).

Fig 1b. The main external features of an adult locust (Chapman 1976).

Locusts and grasshoppers, groundhoppers and crickets are classified as follows:

Order:

\section{Ortophethera}

Suborders:

Ensifera

Caelifera

Long-horned grasshopper

(Tettigonioidea)

Cricket

(Grylloidea)

Mole Cricket

(Gryllotalpidae)

- Antennae as long as body

- Terebra at the end of the female body.

- Male stridulating organs on the tegmen.

- Omnivorus (Tettigonioidea) - Phytophagous or carnivorus (Grylloidea)

\section{Grashoppers and locusts}

(Acridoids)

Superfamilies:

Trydactyloidea

\section{Tetrigoidea}

Acridoidea

- Few antennal segments,

never exceeding half of the body lenght.

- No terebra on the female body.

- No male stidulating on the tegmen.

Source: Pastre et al.(1989) 
Locusts belong to the order Orthoptera, which includes the crickets and grasshoppers. This order is commonly divided into 5 superfamilies. The locusts belong only to one of these; the Acridoidea, which have these characteristics:

- antennae short, less than 30 segments

- tympanal organs on abdomen

- tarsi 3-segmented

- forewings held in a roof-like manner over back

- no elongate ovipositor.

The Acridoidea is the largest of the super-families and includes about 10000 species, which are all basically similar in form.

There are relativly few locust species (see Table 1), but they occur in all warmer regions of the world. 
Table 1. The different species of locusts.

\begin{tabular}{|c|c|c|}
\hline Scientific name & Common Name & Distribution \\
\hline Schistocerca gregaria & Desert Locust & $\begin{array}{l}\text { Northern Africa, } \\
\text { Arabia, Indian } \\
\text { Subcontinent from } \\
\text { about } 10^{\circ} \text { to } 35^{\circ} \mathrm{N} \text {. }\end{array}$ \\
\hline $\begin{array}{l}\text { Schistocerca } \\
\quad \text { americana americana }\end{array}$ & & Central America. \\
\hline $\begin{array}{l}\text { Schistocerca } \\
\text { americana paranensis }\end{array}$ & & South America. \\
\hline Anacridum melanorhodon & $\begin{array}{r}\text { Sahelian tree } \\
\text { locust }\end{array}$ & $\begin{array}{l}\text { In a belt across } \\
\text { Africa south of } \\
\text { Sahara from about } \\
10 \text { to } 20^{\circ} \mathrm{N} \text {, but } \\
\text { extending to the } \\
\text { equator in the } \\
\text { east. }\end{array}$ \\
\hline Anacridium wernerellum & $\begin{array}{r}\text { Sudanese tree } \\
\text { locust }\end{array}$ & $\begin{array}{l}\text { In a zone } \\
\text { further south than } \\
\text { A. melanorhodon. }\end{array}$ \\
\hline $\begin{array}{l}\text { Nomadacris } \\
\text { septemfasciata }\end{array}$ & Red locust & $\begin{array}{l}\text { In Africa, mainly } \\
\text { from the Equator } \\
\text { to about } 30^{\circ} \mathrm{S} \text {. }\end{array}$ \\
\hline Patanga succincta & Bombay locust & South-west Asia. \\
\hline Melanoplus spretus & $\begin{array}{l}\text { Rocky mountain } \\
\text { locust }\end{array}$ & $\begin{array}{l}\text { North America, } \\
\text { said to be extinct. }\end{array}$ \\
\hline $\begin{array}{l}\text { Chortoicetes } \\
\text { terminifera }\end{array}$ & $\begin{array}{l}\text { Australian } \\
\text { plague locust }\end{array}$ & Australia \\
\hline Locusta migratoria & Migratory locust & $\begin{array}{l}\text { Different } \\
\text { subspecies in } \\
\text { Southern Europe, } \\
\text { Africa, Southern } \\
\text { Russia, China, } \\
\text { Japan, Australia } \\
\text { and Philippines. }\end{array}$ \\
\hline Locustana pardalina & Brown locust & South Africa. \\
\hline $\begin{array}{l}\text { Dociostaurus } \\
\text { maroccanus }\end{array}$ & Moroccan locust & $\begin{array}{l}\text { Middle East and } \\
\text { Mediterranean. }\end{array}$ \\
\hline Calliptamus italicus & Italian locust & $\begin{array}{l}\text { Middle East, } \\
\text { China and } \\
\text { Mediterranean }\end{array}$ \\
\hline
\end{tabular}

Source: Chapman (1976) 


\subsection{Reproduction}

Source of this chapter is Chapman (1976) unless otherwise stated, most studies concern Schistocerca gregaria and Locusta migratoria. The locust eggs are slightly curved sausage-shaped and about $6 \mathrm{~mm}$ long. They are laid in a group or clutch up to $15 \mathrm{~cm}$ below the surface of the ground, see Figure 2. The eggs are laid in egg-pods of a rather crisp, frothy material. The egg-pod is built of proteins, and its function is to reduce water loss and to form an easy route by which the newly hatced locusts can reach the surface. The number of eggs in an egg-pod varies with the species of locust, the food situation, the size of the insect, and also with the degree of crowding the insects have experienced.

Eggs are usually laid in areas of bare ground close to vegetation. Females will not oviposiate in dry ground or in waterlogged soil. Apart from these extremes the moisture differs a lot. Saline soils are avoided. A character of locust swarms is that they tend to oviposiate close together.

The embryonic development stops if sufficent water is not available. If moisture becomes available within a few days the only effect is a delay of development. More prolonged lack of water leads to death. Some species have a delay in embryonic development associated with survival over a dry period. The state of diapause may persist for over three years and enables the species to survive long periods of drought

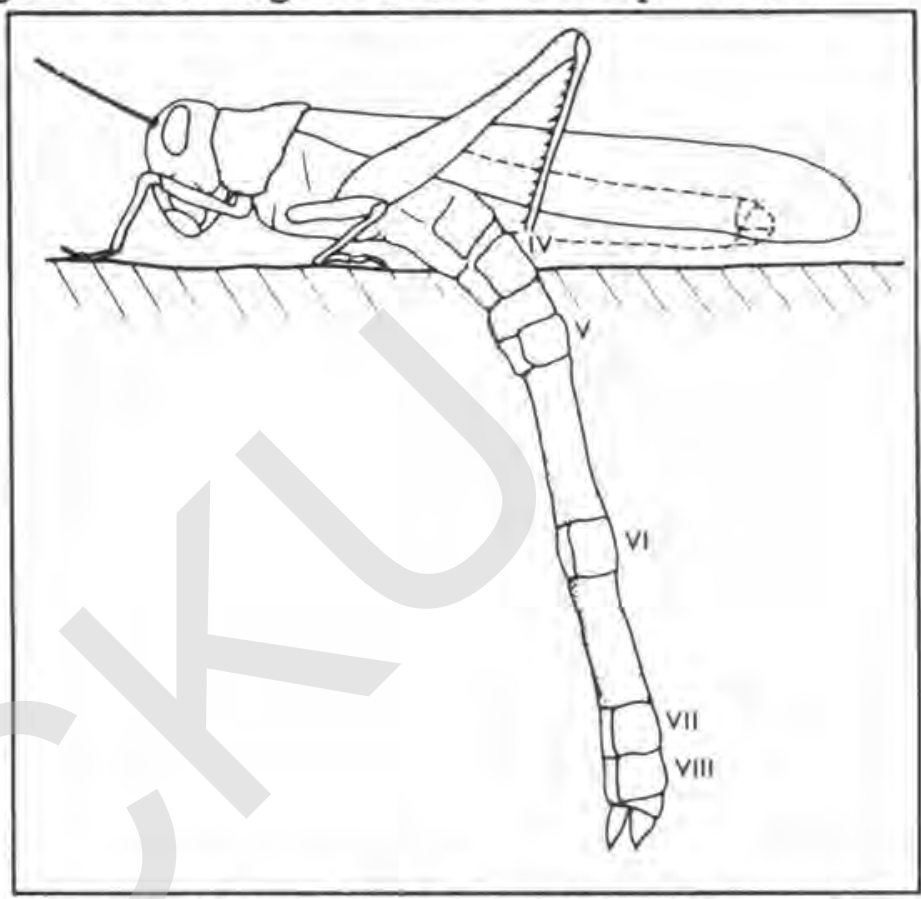

Figur 2. A locust laying eggs. Note the extension of the abdomen. The normal size and position of the abdomen is indicated by the broken line (Chapman 1976). which occur in its habitat.

After hatching the nymphs, or hoppers as they usually are called, goes through several instars, usually five, see Figure 3 . At each instar it becomes progressively larger. Over the first 3 instars, the only marked change involves some enlargement of the wing pads. In the fourth instar, the wing pads twist upwards so that they point over the back of the insect. This position is maintained in the fifth instar in which they are much larger than in earlier instars.

The period of time spent in each instar varies with temperature. At $33^{\circ} \mathrm{C}$ the durations of the five instars are $5,4,4,5$ and 8 days respectively. At $24^{\circ} \mathrm{C}$ the total period of nymphal development may be as long as 45 days while at $42^{\circ} \mathrm{C}$ it is reduced to 20 days. Some species, especially females in the solitarious phase, may go through an extra nymphal instar. 
Locust nymphs, like the adults, are gregarious and show a strong aggregating behaviour. They group together to form bands. These bands, called hopperbands vary in size form a few square meters up to several square kilometers. These bands migrate (march) by walking or making small hops. The distance covered by nymphal bands range from a few kilometers to about 20 kilometers. Most bands tend to move downwind, and generally big bands move further than small

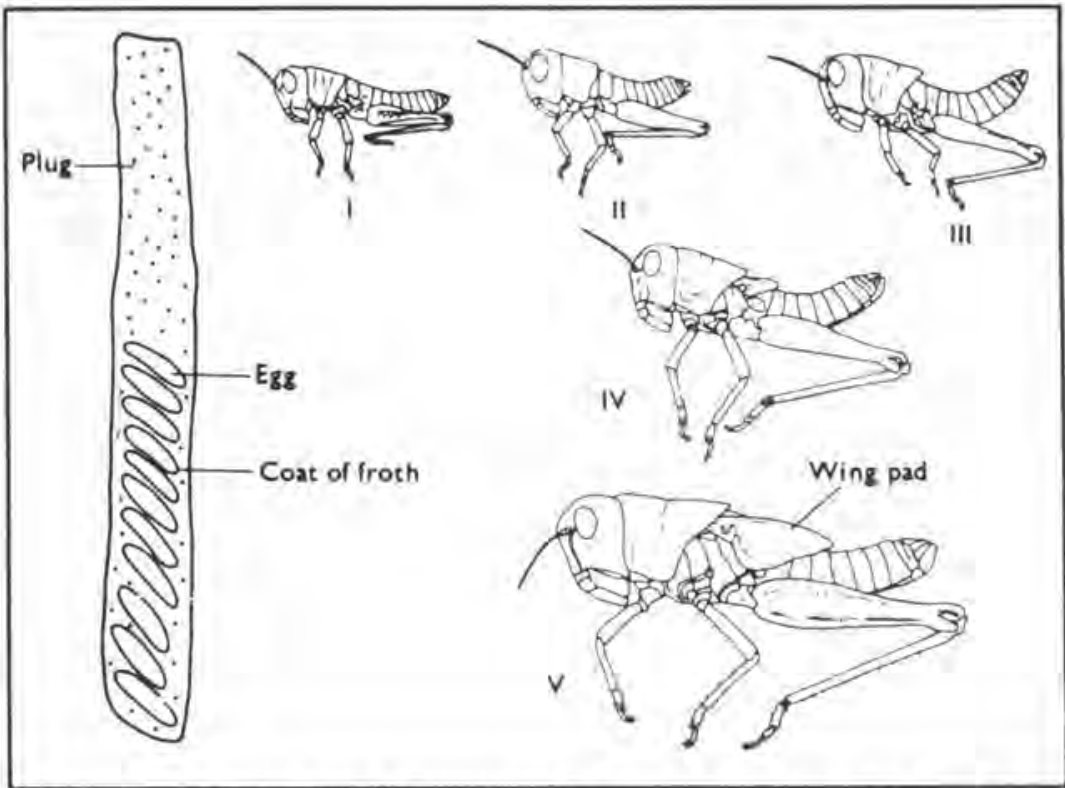

Figur 3. An egg-pod showing the arrangements of eggs, and the five nymphal instars if Locusta migratoria (Chapman 1976). ones.

When the locusts emerges as an adult insect it is not sexually mature. Maturation takes a further week or more, depending on species and conditions. In some species maturation may be delayed for some months under dry or cool conditions. The advantage of this diapause is that the insects only need food for body maintance. They will then easier survive servere conditions. The ability to fly enables them to local movement in search for food.

Solitary locusts make long range flights only at night. Flights seem not occur if the temperature is below $22^{\circ} \mathrm{C}$. Using radar it has been shown that the majority fly at low levels below $400 \mathrm{~m}$, although some fly as high as $1.8 \mathrm{~km}$ above ground. The locust fallow the wind direction, and displacement up to $1000 \mathrm{~km}$ occur regularly for instance in Pakistan.

Gregarious locusts swarm during daytime at hights from just above the vegetation to over 1000 meter above the ground. The locusts can fly at airspeeds of $10-25 \mathrm{~km} / \mathrm{h}$, but the wind can increase their speed significant. Their tendencey for swarms to move with the wind are important because the winds are moving into zones of convergence. That is regions in net horizontal inflow of air exceeds the outflow. In this areas rain tends to fall and the locusts are carried to areas where there is likely to be adequate moisture in the ground for egg development and fresh young plants for the nymphs to feed on. 


\subsection{Phase polymorphism}

Uvarov (1921) was the first to postulate the theory of phases, and he said that locusts could be converted into solitary grasshoppers and that these two forms differ greatly in morphology. By 1928 more information had been accumulated and Uvarov (1928) gave a more succinct statement of the phase theory:

"All gregarious Acrididae, or true locusts, belong to polymorphic species, that is, such are not constant in all their characters, but are capable of producing a series of forms, differing from each other not only morphologically but also biologically. This series is continous, i.e. the the extreme forms are connected by intermediate ones, but these extreme forms are so strikingly distinct that they have been taken for different species. These extreme forms I have proposed to call phases of the species, one of them being by its habits a typical locust, while the other is an equally typical solitary grasshopper". (Uvarov 1928)

These phases Uvarov named gregaria and solitaria, all the intermediate forms being referred to as phase transiens. The transformation is made up from stages, called transition phases, during which locusts are transiens (Pastre et al. 1989): Fig. 3b

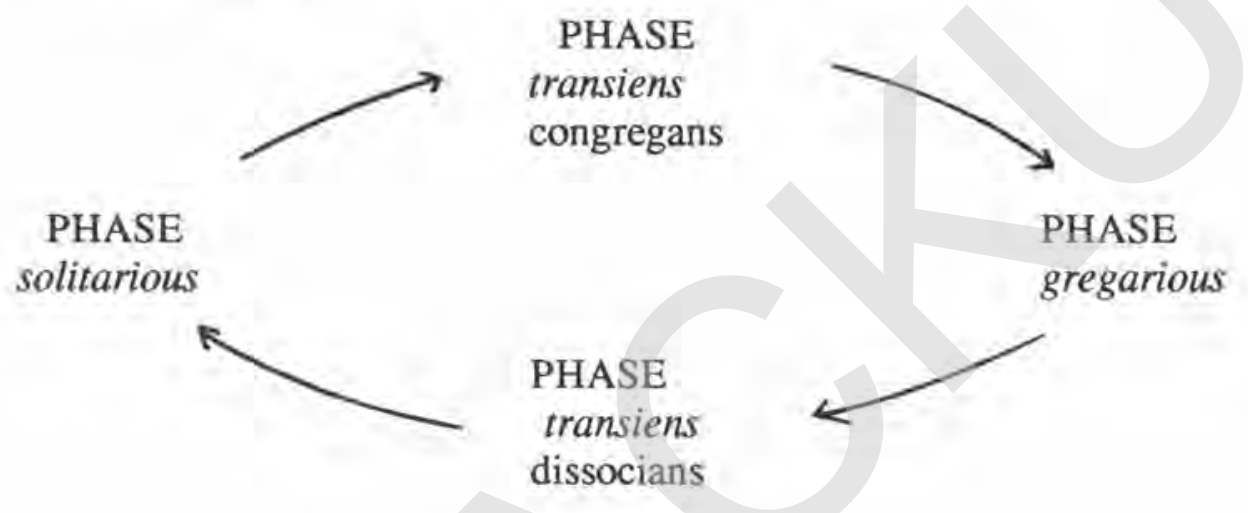

The most pronounced differences are gathered in Table 2 and Fig. 4. Be aware that the differences may vary some from species to species.

Once a locust becomes adult, its morphology can no longer change, but external factors may effect a change in behavior; for example when a swarm settles in dense vegetation interfering with the mutual contacts of the locusts, they may lose the aggregation habit and behave as solitaries, but with morphometrics of the gregarious phase (Uvarov 1966).

An egg-pod of Schistocerca or Locusta may contain two types of egg, large ones producing heavy dark hatchlings, and small ones giving rise to light hatclings (Papillon 1960). Such effects are observed in the Schistocerca eggs laid by females reared crowded and isolated for the first time, so that no selection could have intervened (Uvarov 1966). 


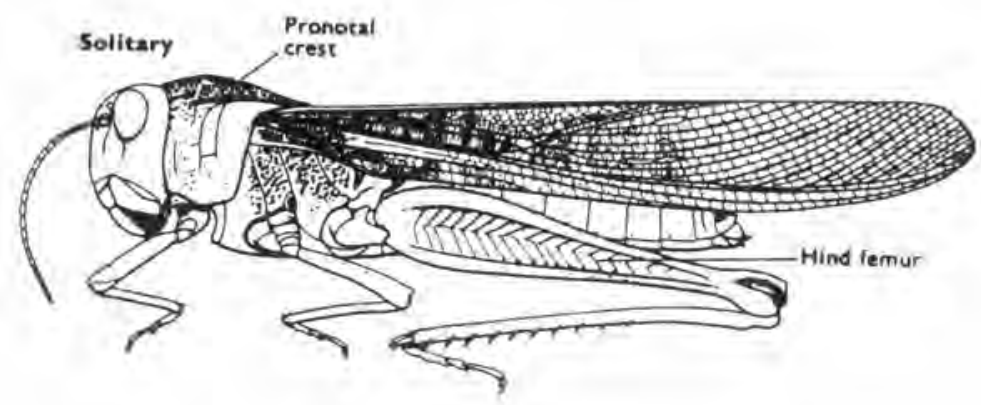

Gregarious

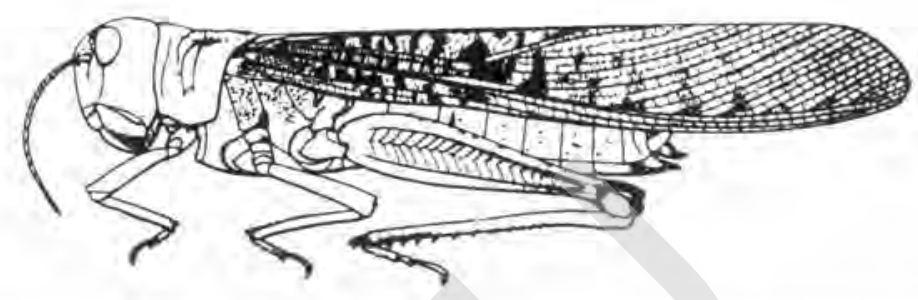

Figur 4. Solitary and gregarious female Locusta drawn to the same scale. Notice the greater size, the high protonal crest and the much larger hind femur of the soliatary insect (from Uvarov 1966). 
Table 2. Some features of Phase Polymorphism in locusts.

Solitaria Gregaria

\section{Behavior}

Tendency to aggregation

Mobility

Actity rhythm

Adult flight

\section{Physiology}

Food and water reserves

at birth

Early mortality of youngs

Development rate

Instar number

Hopper coloration

Absent

Present

Lower

Higher

Not synchronized

Night

Synchronized

Day

Adult coloration

Lower

Higher

Higher

Lower

Slower

Faster

Greater

Fewer

Uniform

Yellow-black

(green)

(no green)

No changes

Changes with

maturiation

and age.

Fecundity

More, but

Fewer, but

smaller eggs.

larger eggs.

Morhpology

Head

Tegmen

Smaller

Shorter

Hind femur

Sexual-size dismorphism

Longer

Pronounced

Larger

Longer

Shorter

Slight

Source: after Uvarov (1961),

\subsection{Population dynamics}

A striking feature of locust is the fluctuations in numbers, see Figure 5. During outbreak years the locust population are growing dramatically and swarms occur outside the breeding areas. In recession years the population are stable or decreasing.

All locusts have in common two basic ecological requirements for their development. Vegetation for food and shelter, and bare ground for oviposition. Because of these requirements they are most abundantly in areas with a mosaic of different vegetation types. Mosaic vegetations commonly develop in zones of contact between two types of 


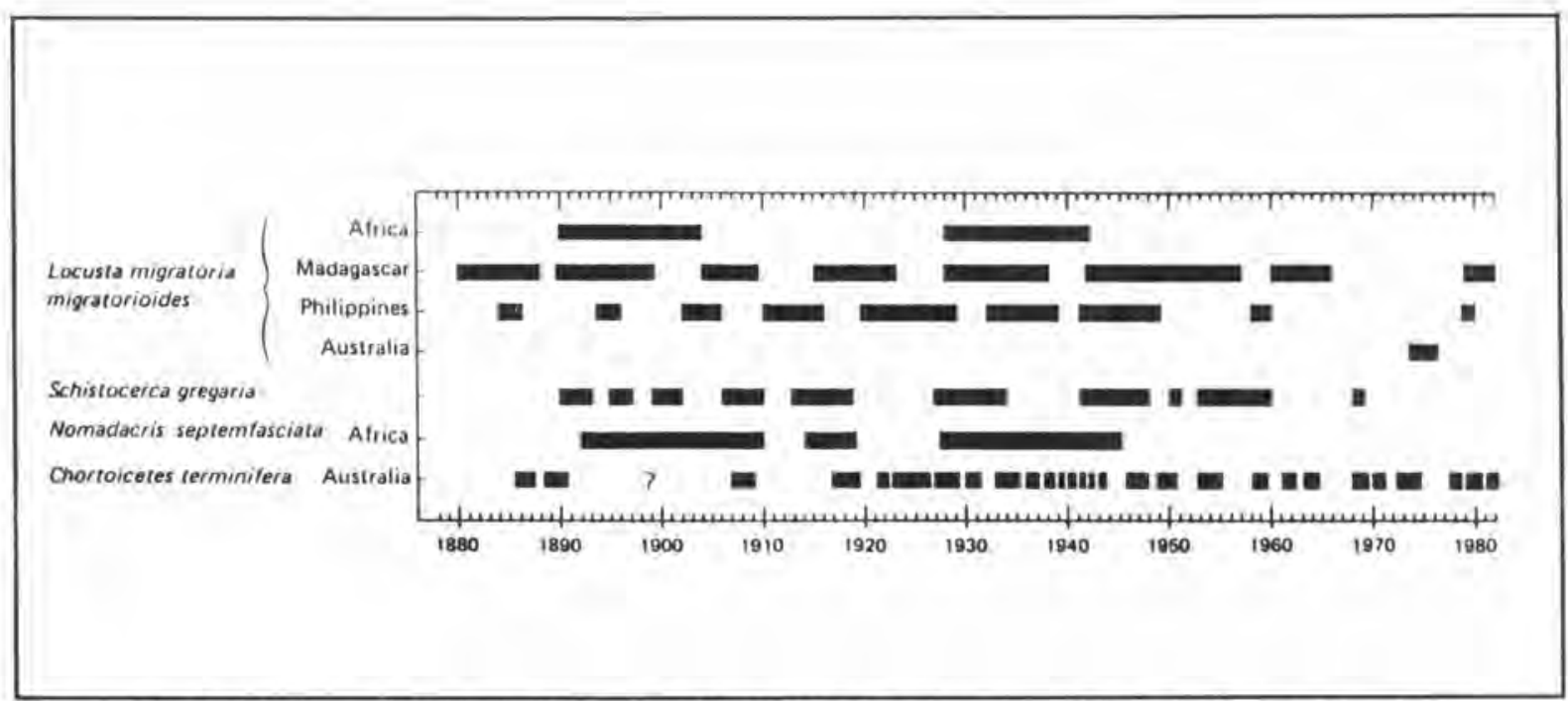

Figur 5. Incidence of locust plaugues 1875-1982. Plague periods indicated by bars (From Farrow \& Longstaff 1986).

plant cover. Typical for this areas is the instability, one or the other component being favoured by the excisting environmental conditions. This instability seems to be closely correlated with locust outbreaks (Chapman 1976). Grasshoppers live in a more continuous habitats than locusts, and phase transformation in locusts may be an adaption to locust's more instable habitat. The formation of swarms is an adaption that allows large populations to survive in an instable environment.

Locust have a great potensial for increase. For instance can a solitary female Red locust theoretically produce 1020 offspring in the first generation. 520000 may be produced in the second generation and 265300000 locusts by the third generation (Chapman 1976). The actual rate of reproduction falls far short ot the potensial, in recession years on the average one female give raise to one male and one female only. 
Table 3. Major limitations on population increase in low-density and swarming locust populations.

\begin{tabular}{|c|c|c|c|}
\hline Stage $L$ & of productivity due to & Low density & Swarming \\
\hline \multirow[t]{2}{*}{ Adults } & egg resorption & $* * *$ & $* * *$ \\
\hline & lack of pod production & $* * *$ & $* * *$ \\
\hline \multirow[t]{3}{*}{ Eggs } & parasites & 0 & $* *$ \\
\hline & predators & 0 & $* * *$ \\
\hline & unsuitable incubation conditions & $* *$ & ** \\
\hline \multirow[t]{4}{*}{ Nymphs } & cannibalism & 0 & $* *$ \\
\hline & parasites & 0 & $*$ \\
\hline & predators & 0 & $* *$ \\
\hline & epidemics & 0 & $*$ \\
\hline
\end{tabular}

Chapman (1976)

*** indicates a common source of loss of productivity

** occasionally important

* rarely important

0 probably not important

According to Krebs the most important factor involved in locust population changes seems to be weather (particularly moisture) operating in and through the process of phase transformation. But the relationship between the weather, phase and density is not fully understood (Krebs 1985). 


\section{4: Locusts in Afghanistan}

\subsubsection{Desert locust Schistocerca gregaria (Forskal)}

Description: Solitarious phase: Largesized, 55-56 $\mathrm{mm}$ (female) or 45-55 $\mathrm{mm}$ (male). Pale brown to greyish body, eyes bearing seven vertical dark stripes. Dark pattern on tegmina. Hyaline wings. Green larvae. Gregarious phase: Smaller size. Immature individuals are pink but their coloration changes from a dark red to bright yellow as they become sexually mature. Black eyes, the six stripes cannot be clearly seen. Yellow hyaline wings. Yellow with black patterns larvae (Pastre et al. 1989).

\section{Distribution: The} solitarious phase of Desert locust is found in the deserts in the African Sahelian areas, on the coasts next to the Red Sea, on the Arabic peninsula, as far as the North-West of India, in the Indian-Pakistan zone, The infestion areas cover a large area, shown in fig. 7 .

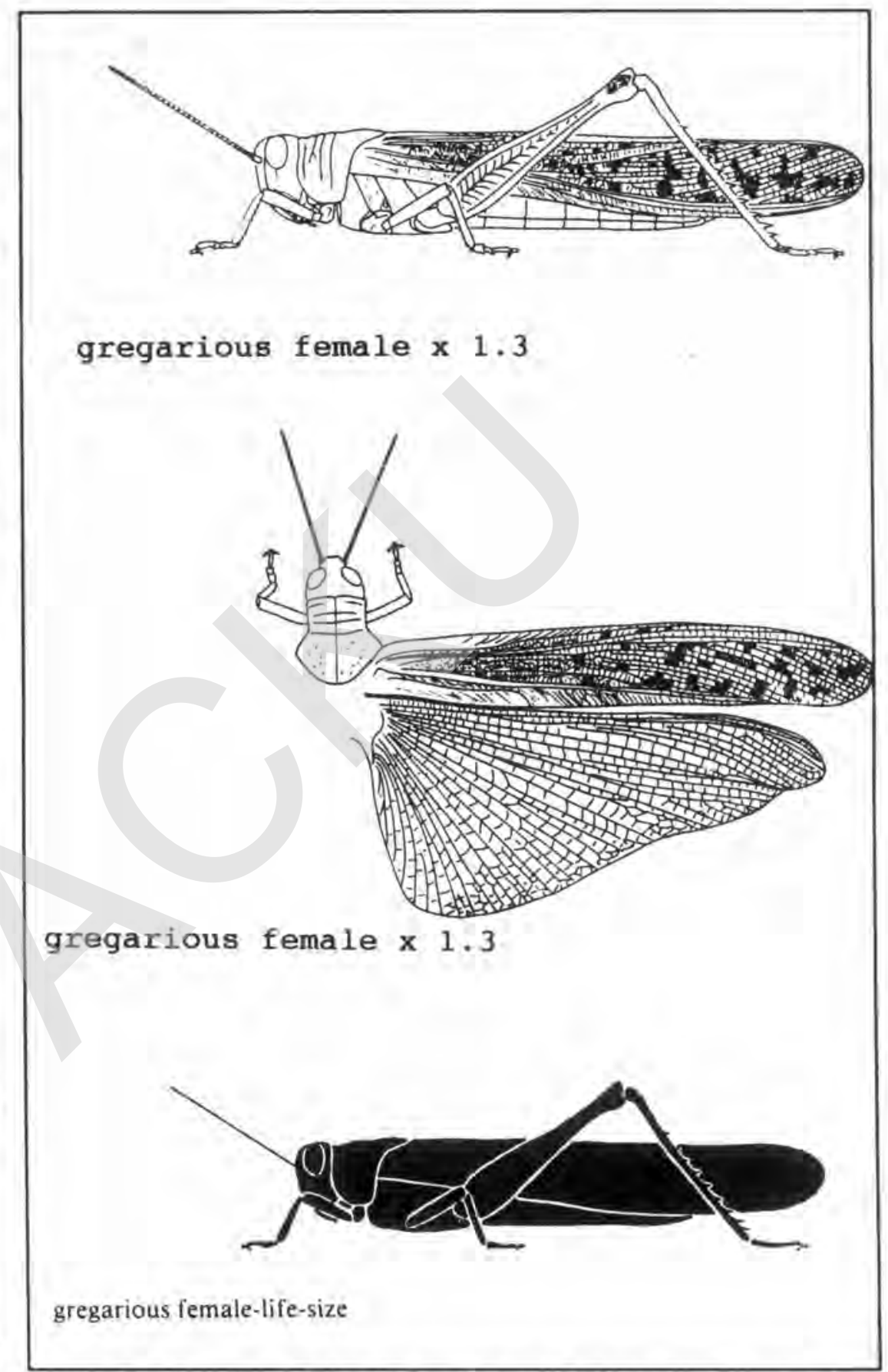

Figur 6. Drawing of the Desert locust Schistocerca gregaria (Pastre et al. 1989). 


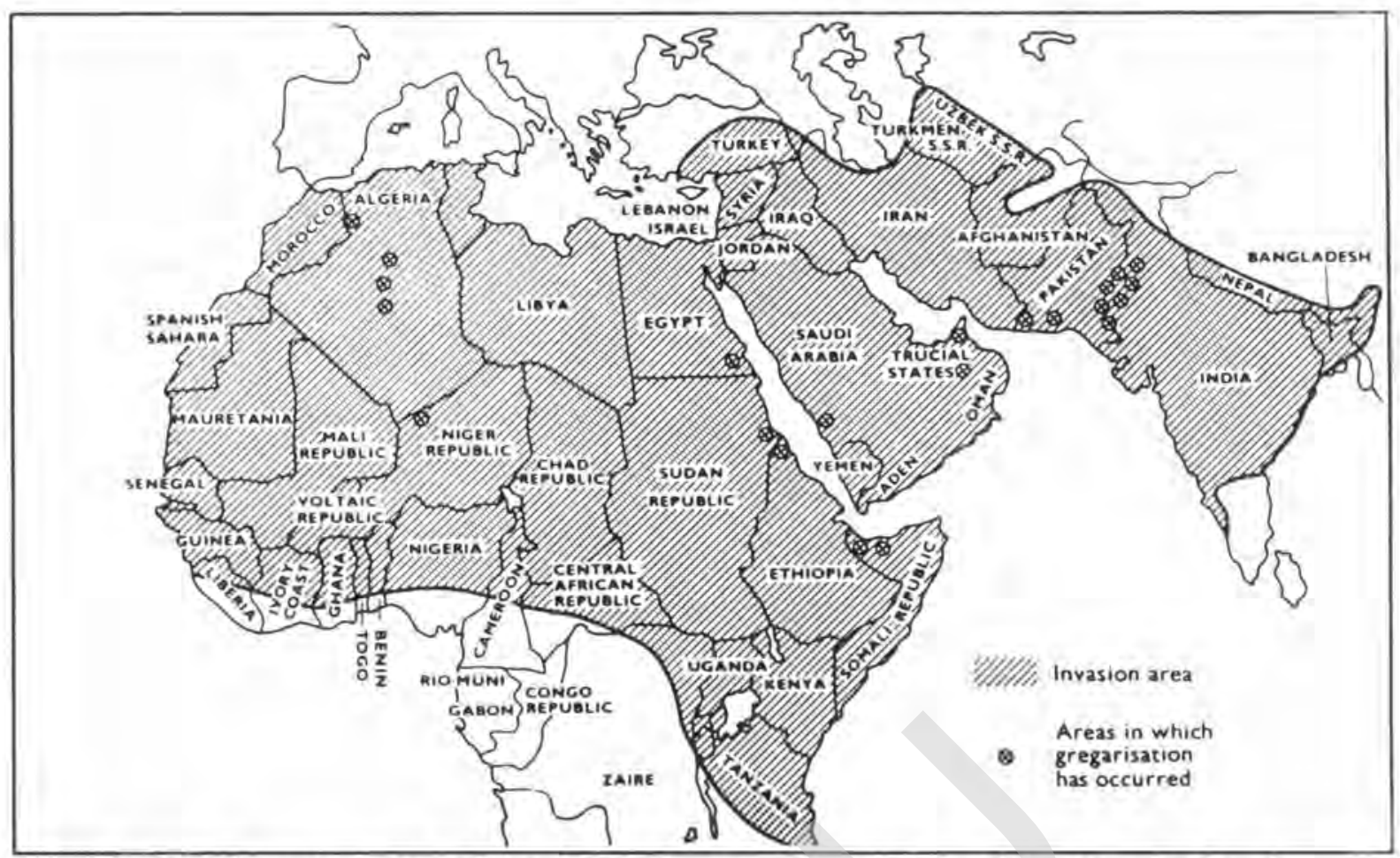

Figur 7. The invasion area of the Desert locust and area in which gregarisation is known or believed to have occured (after Waloff 1966).

In Afghanistan the Desert locust can breed to plague proportions and remain at such level only if there are adequate and spaced rain in the middle of the year (after June-July), which is an extremely rare phenomenon (Sikka \& Singh 1989).

Habitat: The Desert locust prefers to live on open and sandy steppes, on the edges of mountain ranges, on dry river beds and their surrounding areas (Pastre et al 1989). Uvarov (1977) statet that the Sahelian region areas with $50-200 \mathrm{~mm}$ rain falling only during the hot summer period, has the highest frequency of breeding. The breeding habitat is characterized by tussock grass and shrubs on mainly sandy soil. In Soviet Middle Asia invading swarms laid eggs mostly in, or close to, irregated oases, on the banks of rivers and canals and actually in crops (barley, cotton). Oviposition in in sandy desert was confined to depression between dunes with higher soil moisture. One of the general conclusion of all breeding areas was that it tended to be connected with a mosaic pattern of vegetation, whether natural or cultivated. Particularly are ecotunes between contrasting plant communities important. The most areas where gregarisation most frequently occur are the semi-deserts of Pakistan and India and the area on both sides of the Red Sea (Uvarov 1977).

Biology: The diet consists of evergreen and annual plants.

The female lay eggs in a light soil, consisting of a generally dry topsoil $(5$ to $15 \mathrm{~cm})$ and beneath it, a damp layer $(5$ to $15 \mathrm{~cm}$ ). A female lays 40 to 70 eggs at a time and may lay more than three times. The incubation period depend mainly on temperature and can last 10 to 80 days. There are five ( 6 in some solitary individuals) larval stages, and development may last 25 to 50 days. The adult lifespan ranges between 30 to 230 days (Pastre et al. 1989). 
Swarms take off from their breeding areas and cover the infestation area following an East-West direction in Western Africa and a North-East direction in the Oriental infestation area (Pastre et al. 1989). Adult Desert locusts are highly mobile, they may fly non-stop for up to 20 hours and make journeys of hundreds of kilometers (Chapman 1976).

Damage: The Desert locust is the most dangerous locust species especially by immature gregarious phase. They have no special dietary requirements and attack all crops, they may even eat the bark of young branches on fruit trees (Pastre et al. 1989). The Desert locust prefere juicy leaves and fruit, and eat less grass than other locust species.

\subsubsection{Moroccan locust Dociostaurus maroccanus (Thunb)}

\section{Description:}

Species of variable size: the male is 17 to $30 \mathrm{~mm}$ long, the female 15 to 32 $\mathrm{mm}$. Brownish colour, reddish tibia, hyaline wings, yellow abdomen, white cross-like lines on the pronotum (Pastre et al. 1979). Individuals in the gregarious phase are bigger then the those in the solitarious phase.

\section{Geographical range}

The distribution area of Moroccan locust lies in Soviet Middle Asia, the Caucasus, Afghanistan, Iran, Iraq, Syria and Turkey and extends westwards along both sides of the Mediterranean Sea as far as Morocco and to the

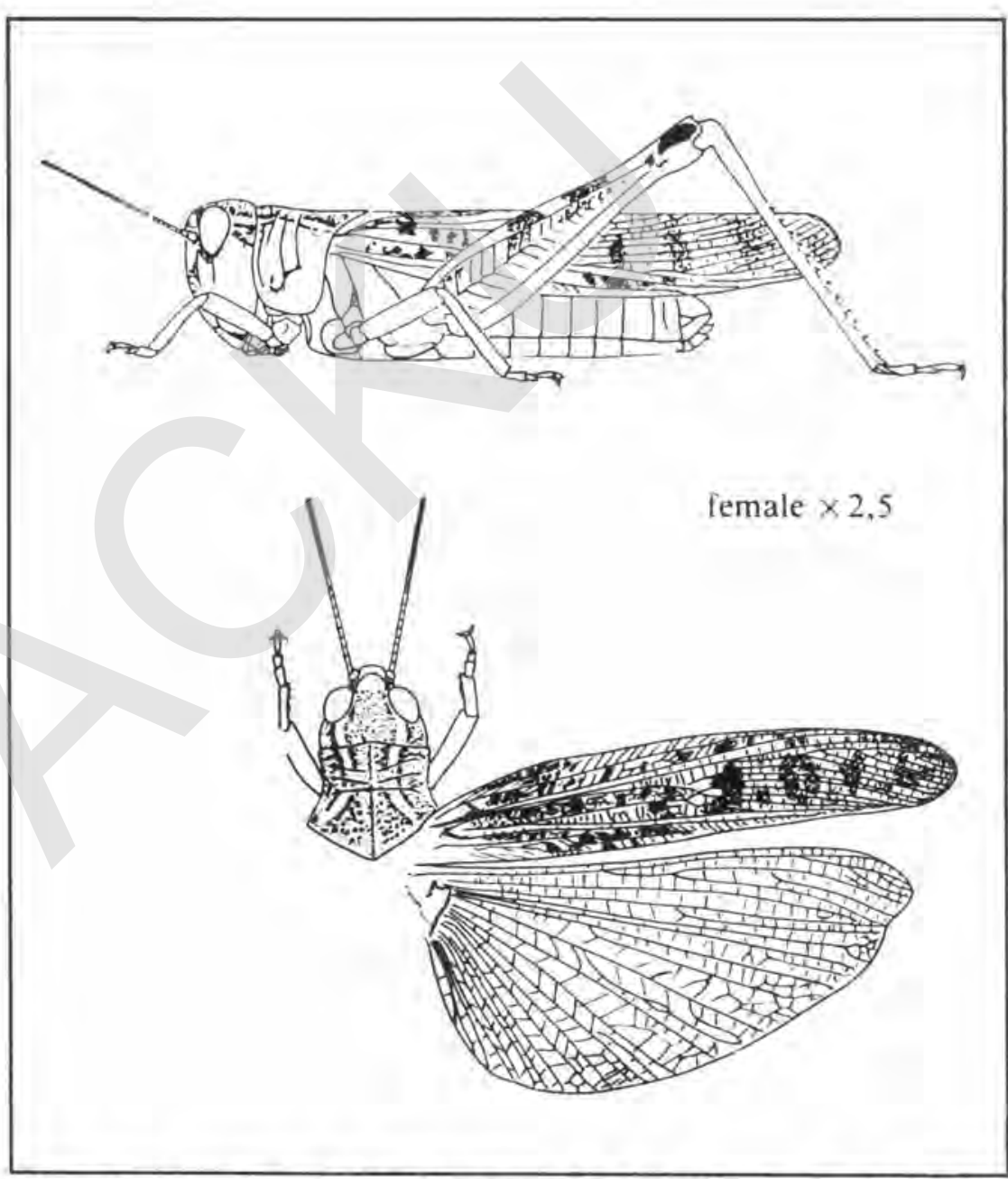

Figur 8. Drawing of the Moroccan locust (Pastre et al. 1989) Canary Islands. Its distribution is characteristically discontinuous, many local populations being clearly isolated (Uvarov 1977). 
Habitat: This species is often quite demanding. The suitable habitat consists of herbaceous cover made up from low-density annuals. The discontious distribution is a consequence of very narrow ecological demands, particularly in terms of the choice of the oviposition sites

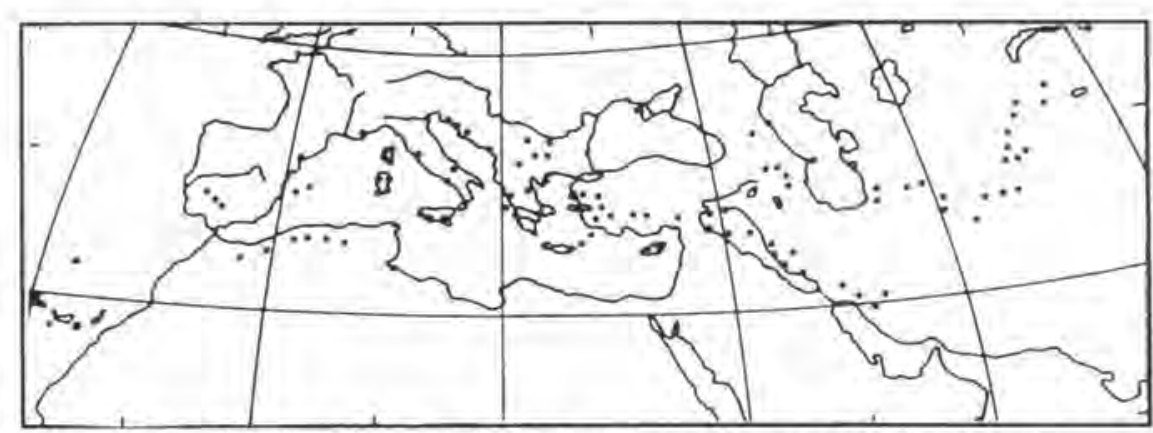

Figur 9. Distribution of the Moroccan locust Dociostaurus maroccanus according to Pastre et al. (1989) modified after Uvarov (1977). Each plot represent a permanent breeding area.

(Patre et al. 1989).

According to Uvarov (1977) the species occur in a definite vegetation type, namely that of semi-arid steppe or semi-desert, with abundant spring ephemerals, particularly short grasses, outstanding among which is the gras Poa bulbosa that figures in practically all habitat descriptions. Other plants also repeatedly mentioned are the short grasses Stipa capensis, Cynodon dactylon, Horeum murinum and small grass-like sedges Carex stenophylla, $C$. hostii which in spring form are almost closed and small dicotyledons such as Medicago minima, Plantago sp., Ranunculus asiaticus; the importance of these members of the plant association differ, however, in different geograpical areas. The vegetation sprouts very rapidly after the first spring rains, but almost completely disappears at the end of the spring, and the summer aspect of the same locations is a mosaic of tall, perennial tussock grasses, herbs and scrublets (Atemisia and others), with bare patches which serve as oviposition sites (Uvarov 1977). In Turkey the resovair areas of Maroccan locust were of the steppe type, 1800-2300 m above sea level (Akinci 1987).

Merton $(1959,1961)$ studied the vegetation changes induced by man in Cyprus and Iran and found abundant evidence that many areas, where outbreak of the Moroccan locust have occurred, were in the recent past covered either by forest or at least macchia. The destruction of the vegetaion and subsequent grazing resulted in a higher populations of locusts. Destruction of the original forest habitats has been suggested for the spreading of the Moroccan locust also in Turkey and Algeria (Uvarov 1977).

Ecology: The number of hopper instars are 5 (Uvarov 1966). From Turkey it is was shown that the infested area expanded in small stages year by year. This is consistent with the limited extent of migratory flights of this species (Uvarov 1932).

The distribution area seems mainly to be limited by the pattern of vegetation, while the population level is regulated mainly by the instability of the environment, the primary natural cause of which is climate. The general decline in the economic importance of the species has probably been due to the expansion of agriculture and the corresponding reduction of potensial oviposition habitats (Uvarov 1977). 


\subsubsection{Italian locust Calliptamus italicus (Linne)}

Description: $19-20 \mathrm{~mm}$ (male) or $26-29 \mathrm{~mm}$ (female). Brown-grey to ferruginous background coloration, with black patterns, which are more or less numerous. Plain coloured pronotum sometimes with two longitudinal stripes underlining the lateral carinae. Tegma extending well beyond the tip of abdomen. Light pink hindwing, hindfemurs are reddish on their inside faces (Pastre et al. 1989). The taxonomic situation for Italian locust and related Calliptamusspecies are unclear.

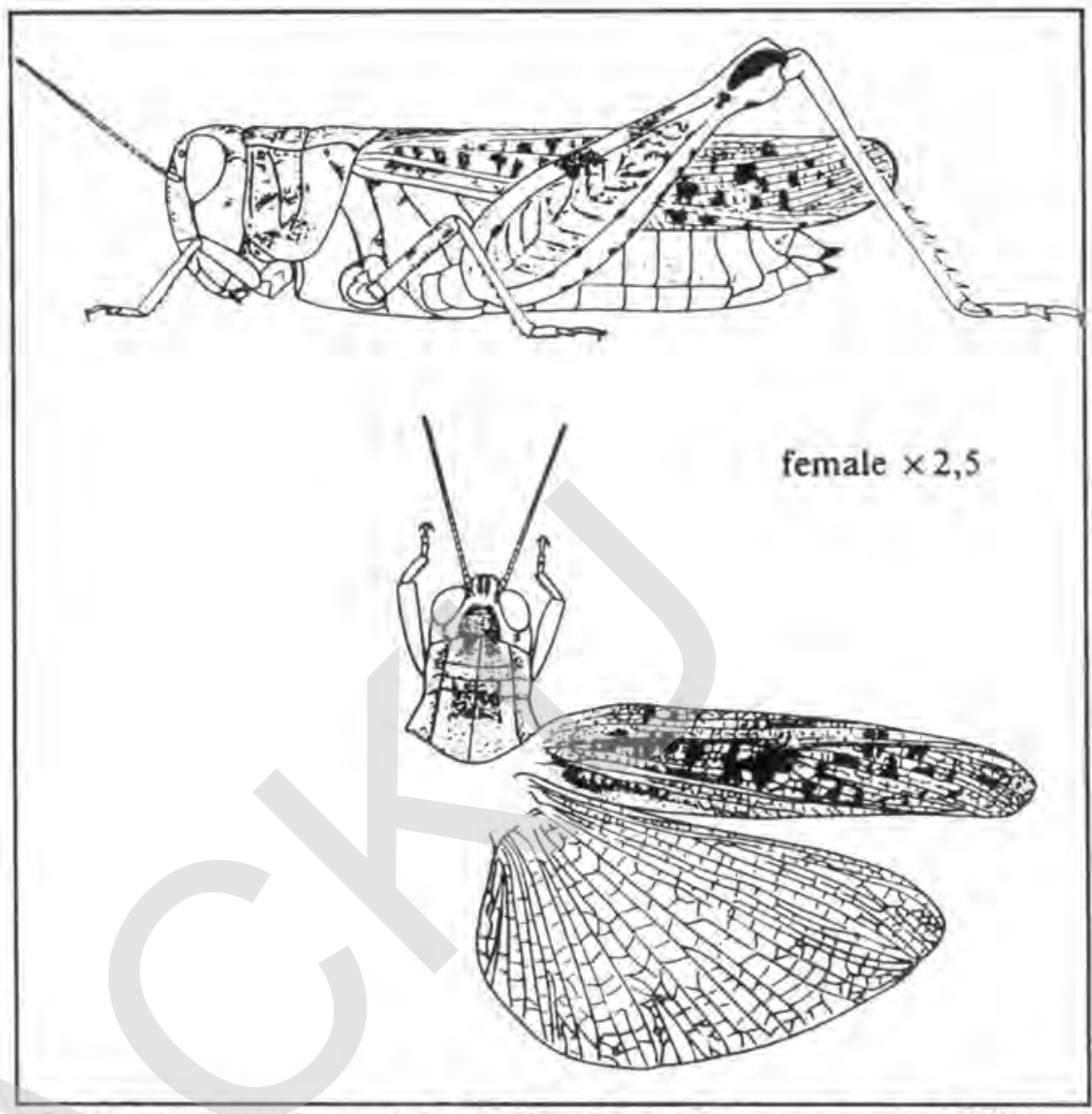

Figur 10. Drawing of the Italian locust (Pastre et al. 1989)

Distribution: The Italian locust occupies a large territory, see Fig. 11: from Transbaikalia, through southern Siberia and the lowlands of Middle Asia, Iran, Asia Minor, the Caucausus, Southern Russia and southern Europe.

Ecology: Local methods of land use, with their effects on soil structure and the related plant succession, should be considered as major factors affecting the abundance of Italian locust in the different areas, even in recession years (Uvarov 1977), see Table 4.

A single generation per year. A succession of hot, dry summers favours the proliferation of the Italian locust. The female lays egg-pods containing about thirty egg each. Six layings can occur (Pastre et al. 1989). The male has 5 hopper instars while females usually have 6 (Pichler 1956). 


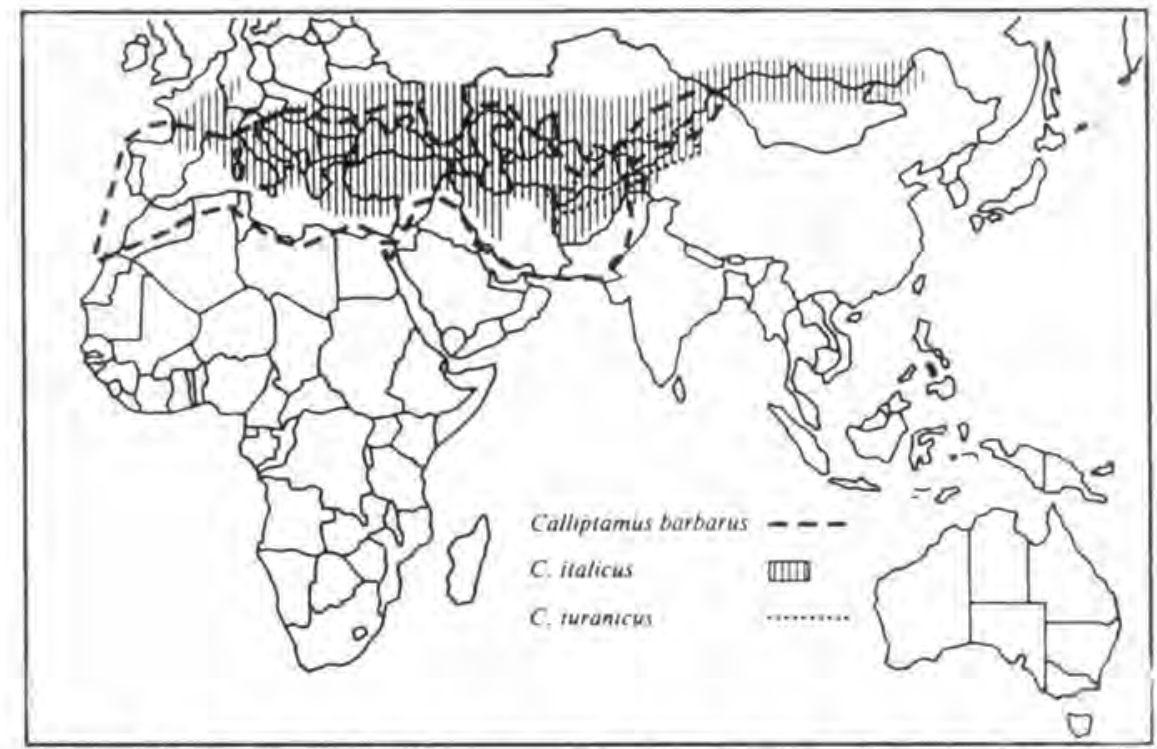

Figur 11. Geograpical range of Italian locust (Pastre et al.)

Table 4. Average adult densities of non-swarming populations of Italian locust in different habitat types in eastern Kazakhstan.

Type of habitat

Number $/ \mathrm{m}^{2}$

1) Virgin land; dense short grass (Festuca sulcata)

2) Patches of Artemesia maritima surrounded by short grass

3) Current year's cultivations (wheat, watermelons, etc)

4) Idle (fallow) land with pure dense tall grass (Agroyron)

5) Early fallow, with some grass, sparse Artemisia and other herbs; bare patches

6) Older fallow, with tall weeds including Artemisia 26

7) Overgrazed communal pasture, with Festuca, Artemisia, Polygonum aviculare, Alyssum, etc.

8) Very old fallow, with dense grass turf (Festuca sulcuta)

During the war in Afghanistan agricultural land has gone out of production because of sabotage, bombing, mines and fewer people. These fields soon develop a mosaic vegetation favourable for locusts which has caused a population increase of locusts. 
Table 4, however, must be used critically. The Italian locust covers a broad specter of habitats. For instance in the more southern oases of the Uzbekistan and Turkmenistan deserts the species occurs only in the immediate vicinity of irrigated areas; eggs are laid in dry soil of dykes, roadsides and waste land with sparse mixed vegetation, but soon after hatching the hoppers move into the nearby crops, particularly lucerne (Uvarov 1977).

\subsection{Locust damage and food situation}

Locusts are an old problem in Afghanistan, but the plagues occur irregularly. The old people we met in Badakshan told they had experienced severe locust plagues when they were young. The South-western provinces in Afghanistan is the area within Afghanistan that plagues occur most frequently in.

The war in Afghanistan have caused vegetation changes that increase the locust population. During the late summer of 1988 it became evident that several provinces of northwestern Afghanistan experienced a severe locust problem, often combined with attacks from some species of seed-eating bugs of the family Pentatomidae, the Sunn pest. The Moroccan locust Dociostaurus maroccanus, which before the war had been effectively controlled with support from the Soviet Union, was now expanding in numbers, causing crop yield losses and food shortage for hundreds of thousands of people.

In 1989 it was decided by Agency Coordinating Body for Afghan Refugees (ACBAR) and The United Nations Organisation for Afghanistan (UNOCA) that the Swedish Committee for Afghanistan/Agricultural Survey of Afghanistan (SCA/ASA), besides running a small scale control program, was to send two survey teams. These teams were sent to all 11 provinces of Northern Afghanistan, totalling over 30 enumerators and supervisors. The aim was to evaluate the damage and prepare a proper program for future locust control. The survey was carried out during the summer of 1989, and it was estimated that a minimum of $1 / 2$ million hectares were infected by the locusts, the Sunn pest or both (The Swedish Committe for Afghanistan 1990 a).

The survey done in 1989 concluded that 10 of the 11 provinces had high wheat production losses because of pest (locusts and Sunn pest) outbreaks (The Swedish Committee for Afghanistan 1990b). Outbreaks of locusts and Sunn pest in Northern Afghanistan affected the livelihoods of nearly 600000 people of the farming population of which over 400000 are already below subsistence because of these outbreaks. The pests have caused exodus of an unspecified number of farm families to cities in Afghanistan and Iran in search of work and food (The Swedish Committee for Afghanistan 1990 a).

According to The Swedish Committee for Afghanistan (1990 a) Maroccan and Italian hopper outbreaks emerged in at least 7 of Afghanistan's northern provinces during the spring of 1989. By midsummer the sucessful hopper bands had developed into numerous swarms of adults. These swarms extend their geographical range beyond the initial regions of hopper emergence. By late summer they had completed their life cycle and laid eggs. The wheat crop losses in the provinces "sustained in excess" of $25 \%$, according to The Swedish Committee for Afghanistan (1990 a). The pest problem in 1990 was about the 
same as in 1989 in Northern Afghanistan (The Swedish Committee for Afghanistan 1990b). Four provinces (possibly five with Balkh) faced critical losses. The provinces of Badghis and Faryab had serious locust and sunn pest problems both years, while Badakshan was seriously affected by locusts

both years, and losses were worse in 1990 than 1989 (The Swedish Committee for Afghanistan 1990 b).

SCA published a food deficit survey for Northern Afghanistan (The Swedish Committee for Afghanistan $1990 \mathrm{c}$ ). They claim that wheat shortage among farming families occurred in all nine provinces. The proportion of farmers who had insufficent wheat to feed themselves for the year, varied between $20-90 \%$, with weighed average of $67 \%$. When we look at provincial food balance, only 3 of the provinces surveyed are in overall surplus for the year up to early summer harvest 1990. Traditionally, all except one, Badakshan, have been wheat exporters. In the worst category are Jowzjan and Badakshan. In both provinces $81 \%$ of farmers had to buy wheat to survive, and $90 \%$ of families declared themselves below subsistence (The Swedish Committee for Afghanistan 1990c).

Our observations from Badakshan showed, however, no big locust problem in the Jurm and Keshim areas (Fig. 13) in 1991. 
5 Experiments with low dosages of the pesticides Deltamethrin (Decis) and Benzene-hexa-cloride (BHC) on the Moroccan locust Dociostaurus maroccanus in Badakshan, 1991. (By Ottesen, P.S., Sondbø, S. \& Zemarai, K.)

\subsubsection{Study area}

The study was done during the last weeks of June 1991. It was localized at $1500 \mathrm{~m}$ above sea level near Farmaqoli, a village $30 \mathrm{~km}$ south of Keshim center in the Keshim Valley, Keshim district in the province Badakshan of north-eastern Afghanistan (Fig. 13). The valley was narrow, with steep, but green slopes terminating in peaks reacing altitudes of more than $3000 \mathrm{~m}$ above sea level. Farmaqoli is situated at the eastern side of a large river running through the valley, at the western side is a large riverplain called Dasht-eBigom (transcribed as it was pronounced) on which the test plots were placed, see Fig. 12. This plain, horizontal and quite homogenous, was a typical Moroccan locust habitat covered with short grass $(<5 \mathrm{~cm})$ and some herbs, mostly from the Cruciferacea family. Bare patches favourable for ovipositing was available. The density of locust was generally higher in the valley sides. The bottom plain was still selected for two reasons. It was

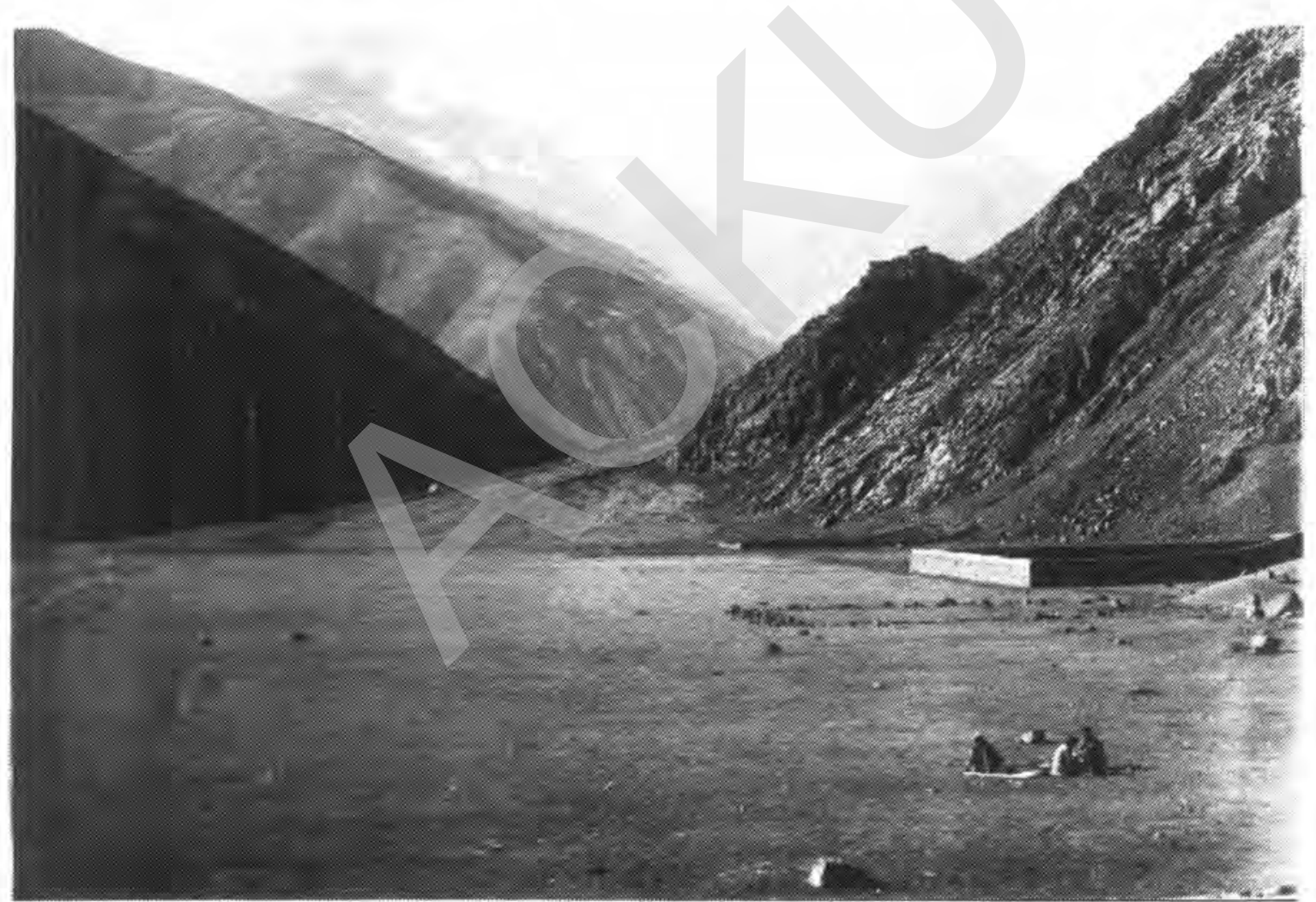

Figur 12. The test area was pasture on a riverplain close to the village Farmaqoli. 


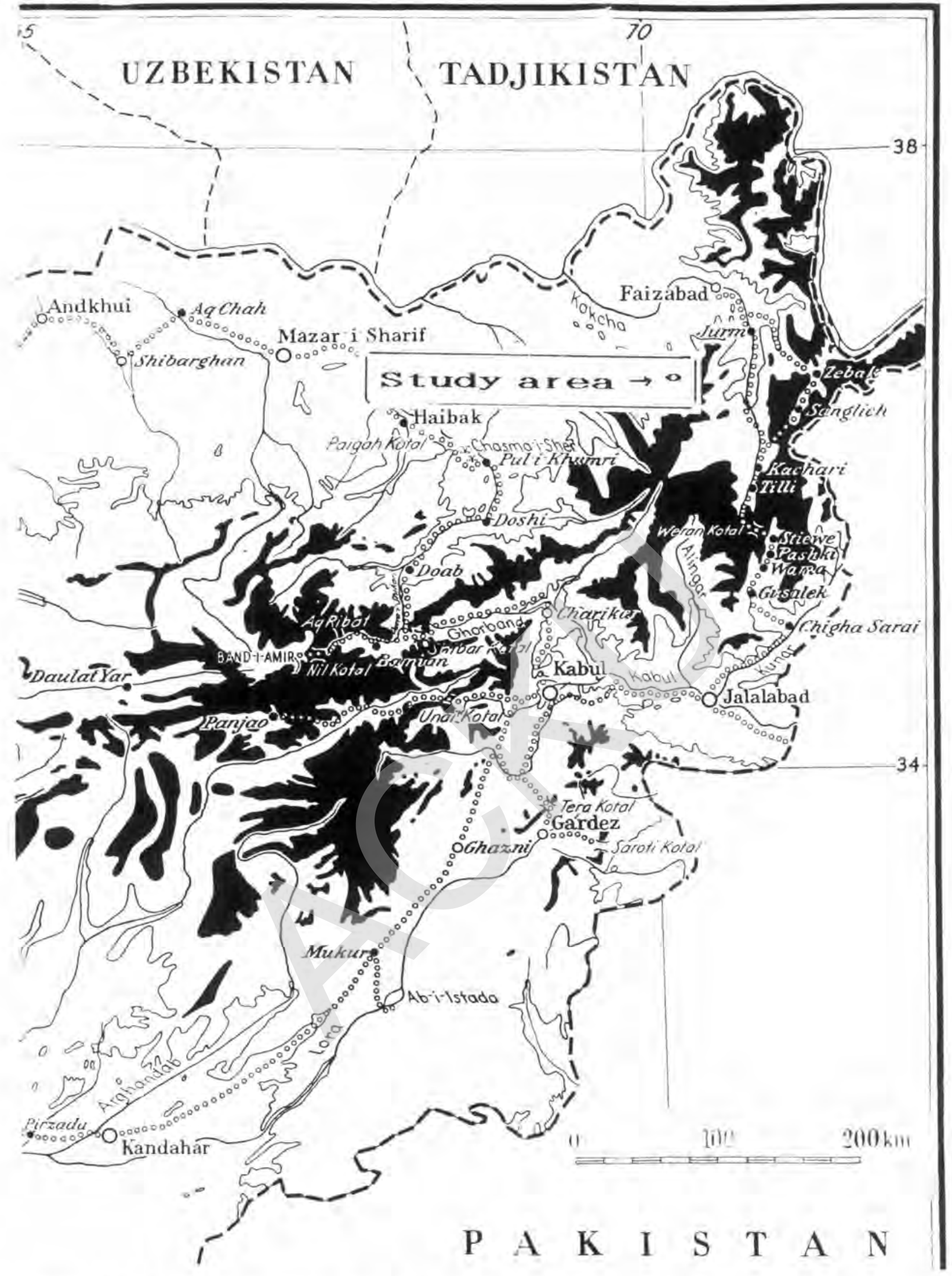

Figure 13. Map over location of study area in Badakshan, Afghanistan. Ground $>3000$ $\mathrm{m}$ above sea level shown in black, $1800-3000 \mathrm{~m}$ altitude grey, areas not reaching 1800 white. Map from Paludan (1959). 
easier to select plots, work and sprau in a horizontal, rather than a very steep, nearly vertical area, and the plain was guaranteed free of mines. The density of locusts at the plain was generally 5-10 per $\mathrm{m}^{2}$. Four other (unidenified) grasshopper species were seen in the study plots, but they constituted less than $5 \%$ of the total locust grasshopper populations. About $10-15 \%$ of the locusts had reaced the imago (adult) stage, the remaining being hoppers of various stages.

Other conspious insects in the study area was beetle species of the family Carabidae, Scarabaeidae and Meloidae, robber flies (Asilidae), wasps (Vespidae) and several species of butterflies, especially Pieridae and Nymphalidae.

\subsubsection{Sampling design}

The plain holding the study plots was about $300 \times 100 \mathrm{~m}$ large. Using a measuring rope and compass it was divided into 29 plots, each measuring $30 \times 30 \mathrm{~m}$ and oriented in north/south direction (Fig. 14). The corners of each plot were marked with plastic ribbons in red/white pattern. The relatively small plot size of $900 \mathrm{~m}^{2}$ was selected to get space for all the plots on the area available. Most of the locusts were in the hopper stage, and thus quite stationary (no hopper band formations in our plots). The small plot size proved adequate for the experiment, although $50 \times 50 \mathrm{~m}$ is a more common size for hand sprayer experiments with locusts. During initial countings, it became clear that the five northwesternmost plots, i.e. plots no. $8,9,10,11$ and 12 , having more dense and green vegetation than the remaining plots, held too few locusts to be suitable for the experiment. In this report, the orginal numbering of the plots will be used, and the reader should then recall why no more reference will be made to these five plots. The remaining 24 plots were divided into eight blocks of three plots each. Two blocks were control areas, receiving no treatment, three blocks received Desic treatments, i.e. the first one having the recommended dosage, the second one a low dosage, and the third one a very low dosage. The last three blocks received BHC treatment, again in three different dosages. Within a block, each plot received individual treatment, i.e. one plot was sprayed and the amount of chemicals used was measured before a new plot in the block was sprayed. The reason for using block rather than random design was that putting similar treatments close to each other reduced the risk of offdrift contamination from plots with different dosage treatment. When selecting treatments for different blocks, care was taken to let the highest dosage being applied in a downwind direction from the plots intended to receive low dosage treatment.

\subsubsection{Counting methods}

In each plot three transects $10 \mathrm{~m}$ long and $5 \mathrm{~m}$ apart were placed in the centre and marked at each end with sticks. In the transects all the locusts, both hoppers and imagoes which appeared within a $2 \mathrm{~m}$ wide area were counted as they escaped through jumping when the counter person walked slowly down the transect. Three persons (Ottesen, Sondbø \& Khan) walked parallelly down the transects, each person counting the same transects through the entire study, and thus eliminating the potential problem of personal differences in counting technique. 
The plots were counted three times each day; in the morning, at noon and in the evening. They were counted for three days before spraying and three days after spraying.

Averagely, the $24 x$ $3=72$ transects had $22.7 \pm 11.8$ (SD) individuals of locusts during the first counting, this number being quite stable in the control plots during the entire study.

\begin{tabular}{|c|c|c|}
\hline$(10)$ & (III) & \\
\hline (9) & (12) & $\begin{array}{l}29 \\
\text { DECIS } \\
\text { Noerdil }\end{array}$ \\
\hline (8) & $\begin{array}{l}13 \\
\text { BHC } \\
\text { MEOIUH }\end{array}$ & \begin{tabular}{|l|}
28 \\
DECIS \\
VORMAL
\end{tabular} \\
\hline $\begin{array}{l}7 \\
\text { BHC } \\
\text { MEOIUH }\end{array}$ & $\begin{array}{l}14 \\
\text { BHC } \\
\text { HEDIOH }\end{array}$ & $\begin{array}{l}27 \\
\text { DECIS } \\
\text { NORMAL }\end{array}$ \\
\hline $\begin{array}{l}6 \\
\text { Control }\end{array}$ & $\begin{array}{l}15 \\
\text { ControL }\end{array}$ & $\begin{array}{l}26 \\
\text { Control }\end{array}$ \\
\hline $\begin{array}{l}5 \\
\text { BHC } \\
\text { Low }\end{array}$ & $\begin{array}{l}16 \\
\text { BHC } \\
\text { LOW }\end{array}$ & $\begin{array}{l}25 \\
8 \mathrm{HC} \\
\text { how }\end{array}$ \\
\hline $\begin{array}{l}4 \\
\text { BHC } \\
\text { ULTRA LOV }\end{array}$ & $\begin{array}{l}17 \\
\text { BHC } \\
\text { ULTRA LoW }\end{array}$ & $\begin{array}{l}24 \\
\text { BHC } \\
\text { OLTKA LON }\end{array}$ \\
\hline $\begin{array}{c}3 \\
\text { DECIS } \\
\text { UTRM Lon }\end{array}$ & $\begin{array}{l}18 \\
\text { OECIS } \\
\text { LOW }\end{array}$ & $\begin{array}{l}23 \\
\text { Contra. }\end{array}$ \\
\hline $\begin{array}{l}2 \\
\text { DECIS } \\
\text { ULTKS now }\end{array}$ & $\begin{array}{l}19 \\
\text { DECIS } \\
\text { LOW }\end{array}$ & $\begin{array}{l}22 \\
\text { Contra }\end{array}$ \\
\hline $\begin{array}{c}1 \\
\text { DECIS } \\
\text { UTIKA Law }\end{array}$ & $\begin{array}{l}20 \\
\text { DECIS } \\
\text { LOW }\end{array}$ & $\begin{array}{l}21 \\
\text { Corrna }\end{array}$ \\
\hline
\end{tabular}

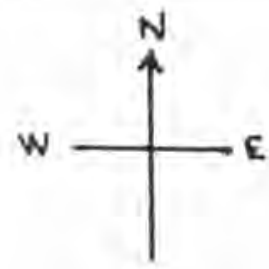

$s$

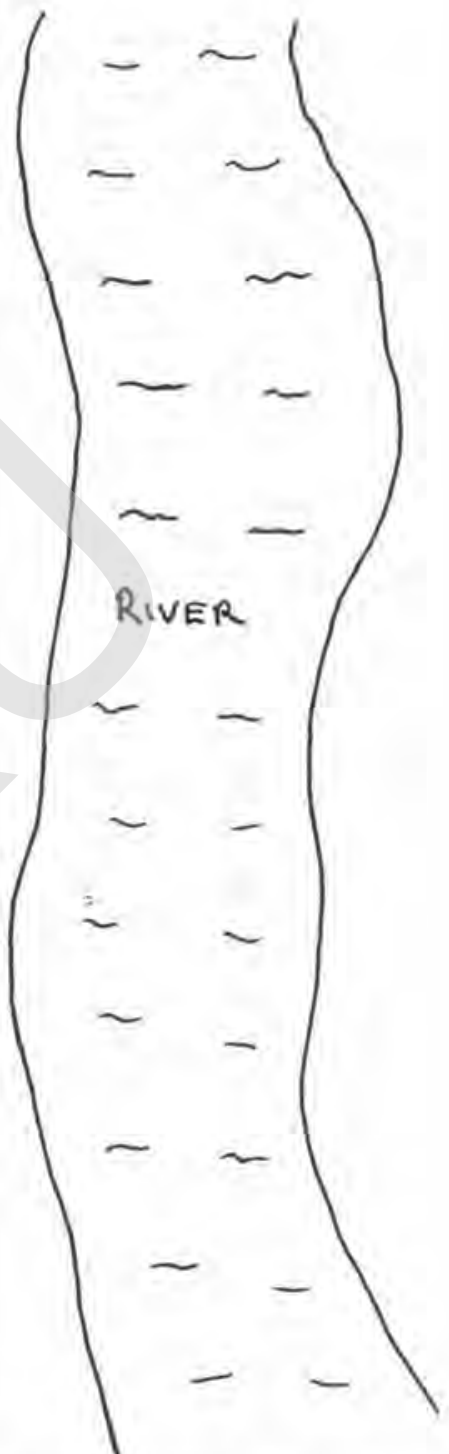

Figur 14. Map over study area in Fermaqoli. Each plot is $30 \times 30$ $\mathrm{m}=900 \mathrm{~m}^{2}=0.09$ ha. 


\subsubsection{Pesticides}

Two pesticides were used, i.e. the artificial pyrethroid Deltamethrin from Roussel Uclaf, France under the trade name Decis $0.5 \%$ ULV and the chlorated hydrocarbon Benzenehexa-chloride (BHC) $12.5 \%$ from Ittehad Pesticides, Kala Shah Kaku, Distt. Sheikhupuru, Pakistan. The Desic was bought in Pakistan, and was delivered in sealed barrels, while the BHC was bought in unsealed bags in the bazaars of Peshawar. According to bag information, the BHC was produced in May 1990 and had expire date April 1993. We brought a sample to Norway for analysis in the Norwegian Pesticide Laboratory, the result are given in Table 5 .

Table 5. Content of the different BHC-isomers

\begin{tabular}{ccc}
$\alpha-\mathrm{BHC}$ & $\mathrm{B}-\mathrm{BHC}$ & $\gamma$-BHC \\
$21.1 \%$ & $5.0 \%$ & $12.6 \%$ \\
\hline
\end{tabular}

The results in Table 5 show that the content of $\gamma$ - $\mathrm{BHC}$ is in accordance with the label on the package. The high content of $\alpha$ - and $\beta$-isomers show that the product is tecnically BHC, and can not be called lindane (cfr. chapter 6.1).

The two low dosages of Decis was diluted with vegetable oil, a mustard seed oil, that was bought at the marked in Peshawar. Mustard seed oil is readily available in Afghanistan, in fact it turned out that a small "factory" produced the oil in Farmaqoli, just across the river from our test plots. It mixes well with Decis.

The French locust centre PRIFAS recommends $12.5-15 \mathrm{~g}$ a.i./ha of Decis against locusts (Launois-Luong et al. 1988), and we decided to test the effect of this dosage on the Moroccan locust as a baseline. As $6 \mathrm{~g}$ a.i./ha was shown to be higly efficient against the Sahelian tree locust in Sudan (Ottesen et al. 1990), we decided further to test $3 \mathrm{~g}$ a.i. /ha against the Moroccan locust and a very low dosage of $1.5 \mathrm{~g}$ a.i./ha, expected to be too low to work satisfactory, but helpful to evaluate the minimum dosage.

Concerning BHC, we had received information from the Sate Pesticide Control Agency in Norway that this pesticide is equivalent to Lindane. During the Afghanistan spraying program it was recommended that $20 \mathrm{~kg} / \mathrm{ha}$ was used of a $12 \%$ formulation, i.e. $2.4 \mathrm{~kg}$ a.i./ha. PRIFAS, however, recommend $8 \mathrm{~kg} / \mathrm{ha}$ of a $2 \%$ Lindane formulation, giving $0.16 \mathrm{~kg}$ a.i./ha (Lanious-Loung et al. 1988). This enormous difference made us doubt the statement that these two pesticides are equivalent, but the chemical analysis (Table 5) clearly show that the BHC contained gamma-BHC which is the active ingridient in lindan. As $2.4 \mathrm{~kg}$ a.i./ha for years have shown to be efficient against the Moroccan locust in Afghanistan, we decided to test approximate half dosage, i.e. $1.1 \mathrm{~kg}$ a.i./ha, the PRIFAS dosage $1560 \mathrm{~g} \mathrm{a.i./ha}$ and the half of this dosage, $80 \mathrm{~g} \mathrm{a.i./ha.}$ 


\subsubsection{Spraying and dusting techique}

The Decis, with and without mustard seed oil, was applied with a Micro ULVA sprayer for Micron Sprayers LTD., England loaded with six $1.5 \mathrm{~V}$ fresh batteries giving 9 volt. Rotation speed of the atomizer disc was measured with a wire tachimeter to 11000 rotations per minute (rpm) without pesticides, and $10200 \mathrm{rpm}$ with pesticides running. According to the producer, this would give a droplet size of approximately $60 \mu \mathrm{m}$. For the highest dosages i.e. approx. 12.5 and $3 \mathrm{~g}$ active ingridient/hectare the red nozzle was used. Calibration was done with the spinning disc removed, measuring the amount in the bottle before and after letting the pesticide flow for 3 minutes, using a $250 \mathrm{ml}$ laboratory measurement cylinder. Calibrations were done with pure Decis at 18 and $26^{\circ} \mathrm{C}$, showing flowrates of $40 \mathrm{ml} / \mathrm{min}$ at $18^{\circ} \mathrm{C}$ and $48.5 \mathrm{ml} / \mathrm{min}$ at $26^{\circ} \mathrm{C}$. These calculations aided us in estimating swath widths and thus the $\mathrm{g}$ a.i./ha to be used in each plot. Walking speed was kept close to 60 $\mathrm{m}$ per min. However, the amount actually applied to each plot, which could deviate somewhat from the planned amount due to differences in walking speed etc, was carefully calculated to the nearest $\mathrm{ml}$ by measuring the amount in the bottle before and after spraying of each plot. The plots receiving the lowest dosages of Decis were sprayed with the Micro ULVA equipped with the orange nozzle, giving a flowrate of $15 \mathrm{ml} / \mathrm{min}$ when the Decis was mixed $1: 1$ with mustard seed oil at a temperature of $20^{\circ} \mathrm{C}$.

During spraying, the sprayer went

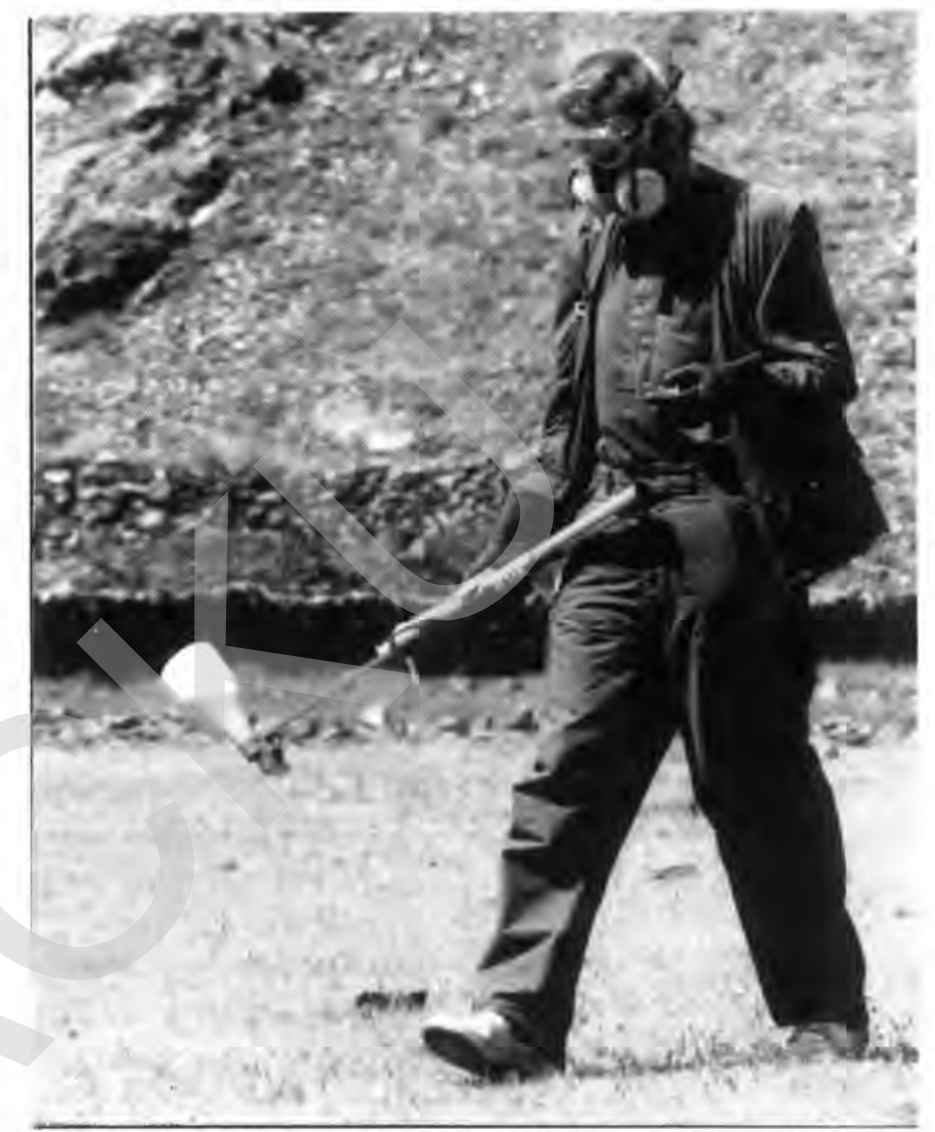

Figur 15. Ottesen spraying deltamethrin with Micro-Ulva handheld batteryoperated spinning disc sprayer. with a stopwatch between pins with white plastic ribbons that indicated the transect lenght. He was equipped with rubber gloves, laboratory safety glasses and a face mask with proper filter for organic aerosols.

Evaluation of the spraying was done by applying oil sensitive paper from Ciba-Geigy, Switzerland on plastic discs $10 \mathrm{~cm}$ above the vegetation. They were analyzed through a hand lens at $12 \times$ magnification.

The BHC was weighed on a Pesola spring balance $(0-300 \mathrm{~g})$ and mixed with dry, fine grained mineral soil giving about $7 \mathrm{~kg}$ material to be spread out in each plot. This amount 
proved satisfactory to spread, as a handful spread in a way and at a speed similar to sowing wheat. Walking at normal speed gave the desired, homogenous and correct amount in the plots. Also here the personnel doing dusting had rubber gloves, safety glasses and masks.

Table 6. Techinical data on the pesticide and conditions for spraying deltamethrin.

\section{Chemical data}

Pesticide

Trade name

Producer

Producer formulation

Dilution oil

Dose

Dilution pesticide:oil

Dilution formulations

(g a.i./ha)

\section{Spraying data}

\section{Plot size (m)}

Plot area $\left(\mathrm{m}^{2}\right)$

No. of replicats

Field number

Date

Start hour

Temperature $\left({ }^{\circ} \mathrm{C}\right)$

Wind speed $(\mathrm{m} / \mathrm{s})$

Wind direction

Walk speed $(\mathrm{m} / \mathrm{min})$

Walk direction

Swath width (m)

Droplet diameter $(\mu \mathrm{m})$ *

Rotations per minute

of sprayer (rpm)

Application rate ( $\mathrm{l} / \mathrm{ha})$

Active ingredient per

hectar (g a.i./ha)
: Deltamethrin

: Decis

: Roussel Uclaf

$: 0.5 \%=5$ g a.i. pr 1

: mustard seed oil

: Normal

: $1: 0$

Low

1:1

2.5

Ultra-low

$1: 2$

1.67

$$
: 30 \times 30
$$$$
: 900
$$$$
: 3
$$

; $27,28,29$

: 25 June

: 07.30-08.30

: $18,18,23$

: $1.2 ; 1.3 ; 2.7$

: NS, NS, NS-E

: 60

EW, EW, EW-NS

$: 2.73$

: 60

$: 10200$

: $3.24 ; 2.24 ; 2.64$

: $16.2 ; 11.2 ; 13.2$
$30 \times 30$

900

3

$18,19,20$

25 June

09.25-10.10

$20,24,24$

3. $0 ; 4.5 ; 5.3$

NS

60

EW

$6.0 ; 4.0 ; 4.0$

60

10200

$0.87 ; 1.24 ; 0.73$

$2.2 ; 3.1 ; 1.8$
$30 \times 30$

900

3

1. 2,3

25 June

16.30-17. 10

$23,22,23$

2.1;1.3;0.7

NS

60

EW

4.3;5.0;5.0

60

10200

$0.94 ; 0.79 ; 0.78$

1,$6 ; 1,3 ; 1,3$

*) As read from Micron pamphlet

Control areas 21, 22, 23, 6, 15 and 26. 
Table 7. Technical data on the pesticide and conditions for spraying - BHC.

\section{Chemical data:}

Pesticide

Trade name

Producer

Producer formulation

( g a.i./kg)

Dilution medium

Dose

Dilution BHC:soil

Spraying data:

Plot size (m)

Plot area $\left(\mathrm{m}^{2}\right)$

: $30 \times 30$

Number of replicats

$: 900$

Plot areas

Date

Start hour

Temperature $\left({ }^{\circ} \mathrm{C}\right)$

Wind direction

Wind speed $(\mathrm{m} / \mathrm{s})$

Walk diection

Swath width

Active ingridient per

hectar (g a.i./ha)

: BHC
: Benzene-hexa-cloride $(=\mathrm{BHC})(=\mathrm{HCH})$

: Ittehad Pesticides, Pakistan.

$: 125 \mathrm{~g}(=12.5 \%)$

: Dry, finegrained soil.

: medimum low

: $800 \mathrm{~g}: 6 \mathrm{~kg} \quad 120 \mathrm{~g}: 7 \mathrm{~kg}$

uItra-low

$60 \mathrm{~g}: 7 \mathrm{~kg}$

$30 \times 30$

$30 \times 30$

900

900

3

$5,16,25$

25 June

17.45

20

NS

0.5

EW

1-2

167
3

$4,17,24$

25 June

18.15

I0

NS

0.5-1

EW

1-2

83

Control areas: 21, 22, 23, 6, 15 and 26 . 


\subsubsection{Spraying}

Analysis of the soil sensitive papers showed that the Decis spraying was techinacally successful for the low and normal dosage, giving $>20$ droplets $/ \mathrm{cm}^{2}$. For the lowest dosage, there were fewer droplets, showing that more oil should have been mixed with the Decis to increase droplet numbers and thus increase the chance for hitting insects or their potensial foods. Average wind speeds during spraying ranged from 0.7 to $5.3 \mathrm{~m} / \mathrm{s}$ and the wheather was cold for the season, with temperatures ranging from 18 to $24^{\circ} \mathrm{C}$. Wind direction was exactly or near perpinducular to the walking direction during spraying. Further details on the Decis spraying, the amounts actually applied to each plot, temperature and wind conditions are given i Table 6.

The application of BHC was less complicated, and the dust seemed to be successfully spread over the plots in a homogenous manner. Details on the conditions during application and the amounts are given in Table 7. 


\section{Fig. 16a Decis Normal Dosage}

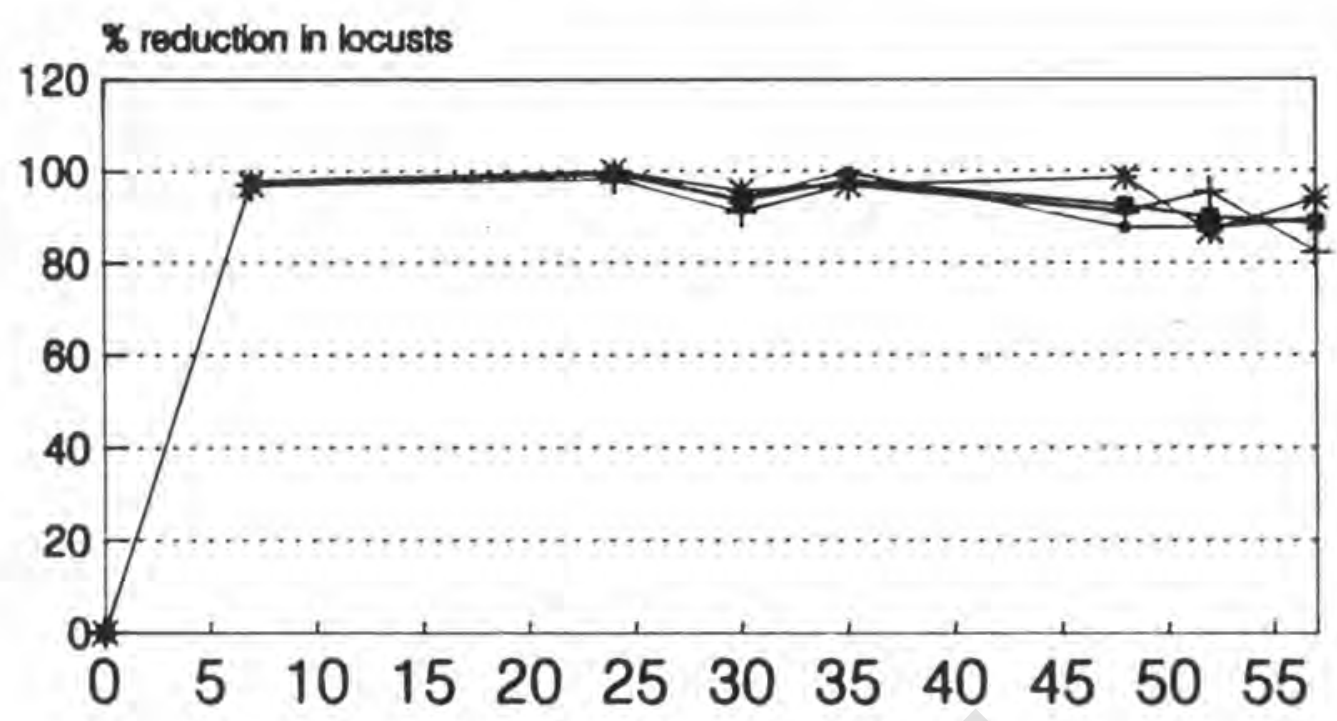

Hours after pesticide application

- Plot 27 + Plot 28 * Plot 29 - Mean

Doseges; 16.2, 11.2 and $13.2 \mathrm{~g}$ a.t.he

\section{Fig. 16 b Decis \\ Low dosage}

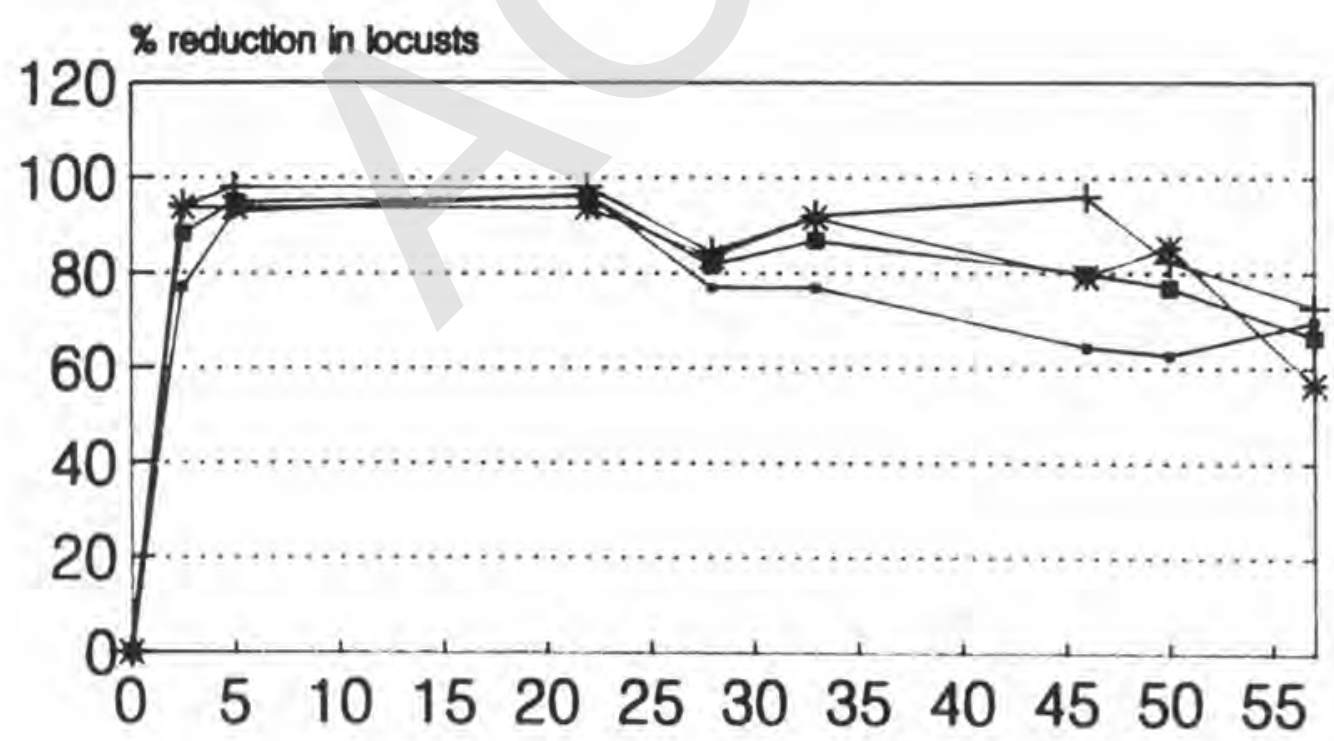

Hours after pesticide application

$$
\text { -Plot } 18 \text { + Plot } 19 \text { * Plot } 20 \text { - Mean }
$$

Dosages: $2.2,3.1$ and $1.8 \mathrm{~g}$ a. $1 / \mathrm{ha}$ 
Fig. 16 c Decis

Ultra Low Dosage

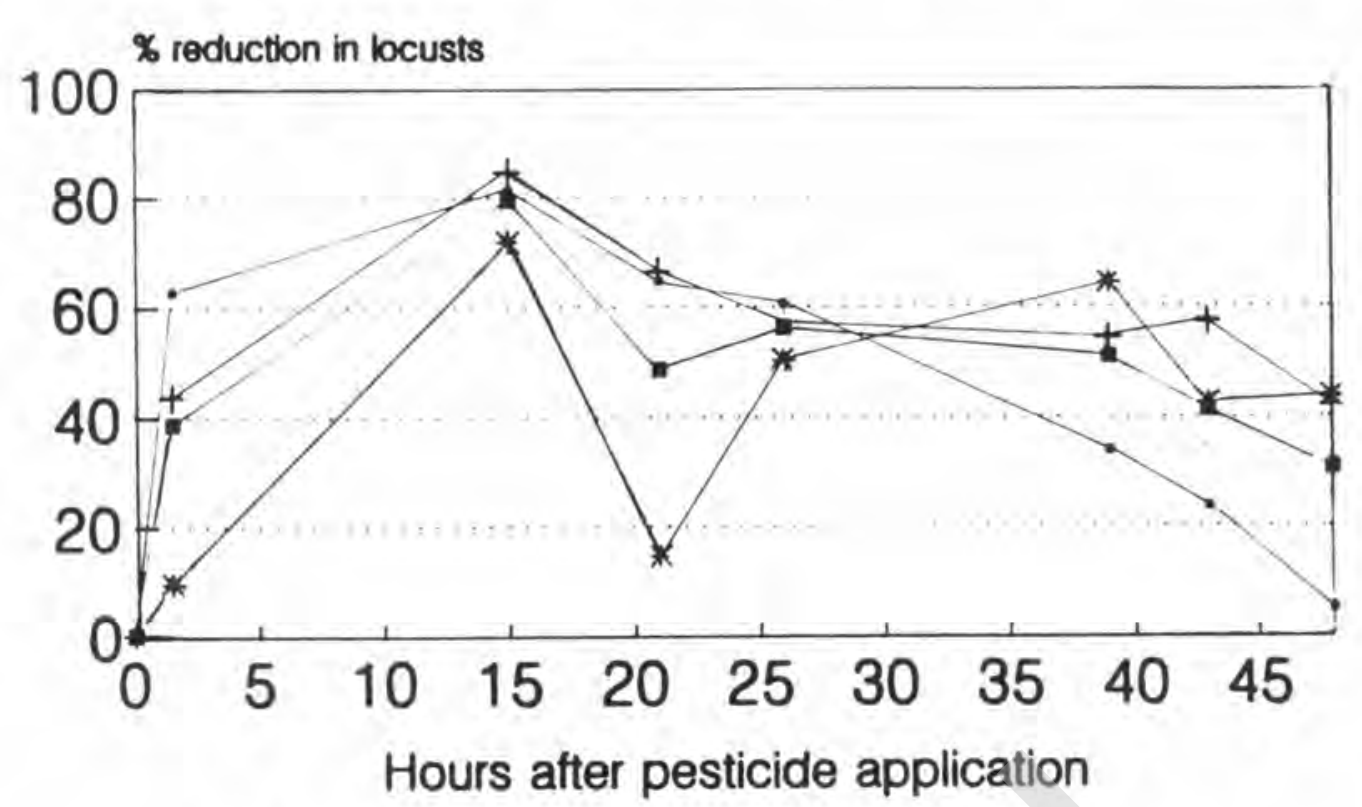

- Plot 1 + Plot $2 *$ Plot 3 - Mean

Dosages; $1.6,1.3$ and 1.30 e.t/ha

\section{Fig. 17a BHC \\ Medium Dosage}

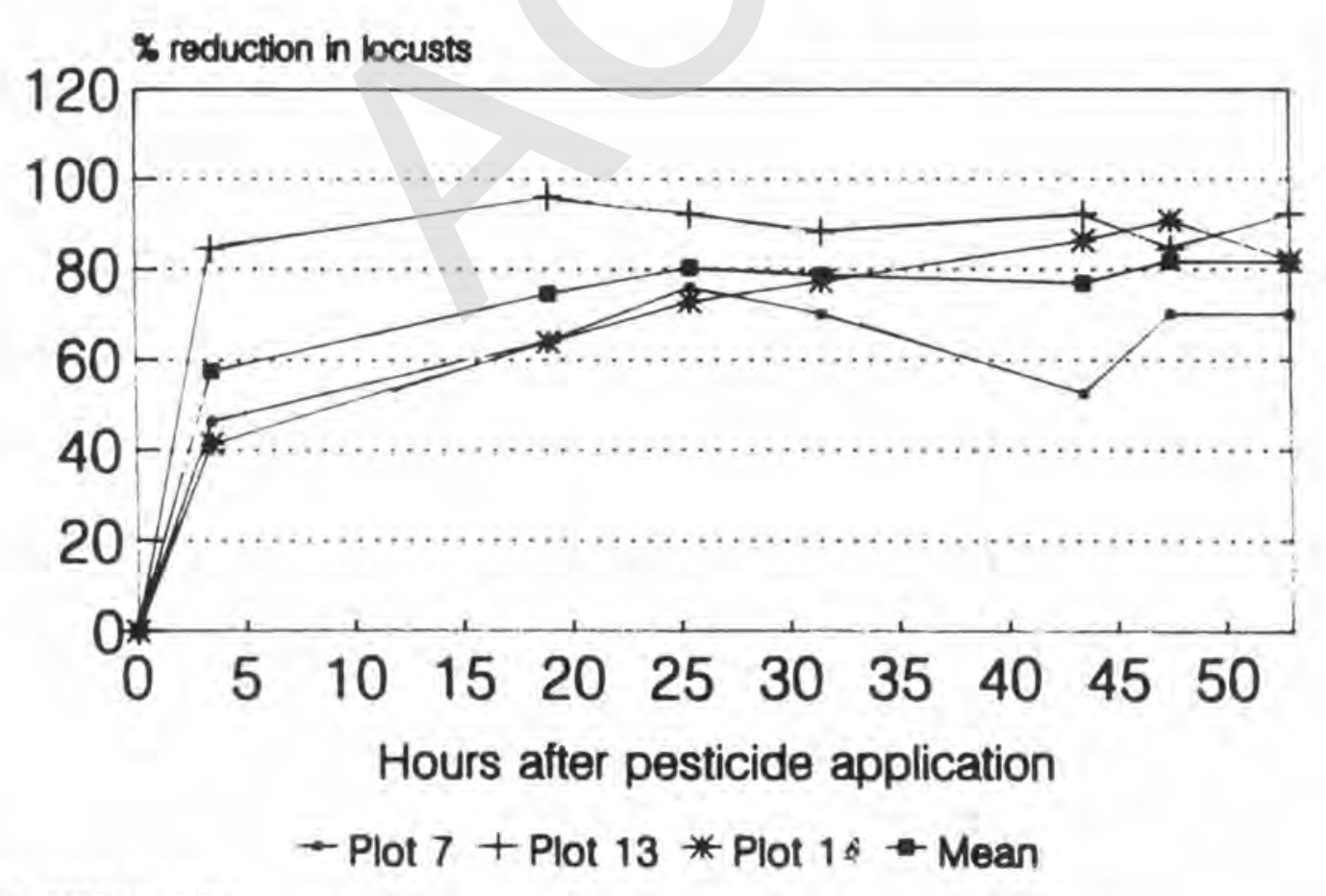

Dosages; 1111 o a.i.ha 


\section{Fig. 17b BHC \\ Low dosage}

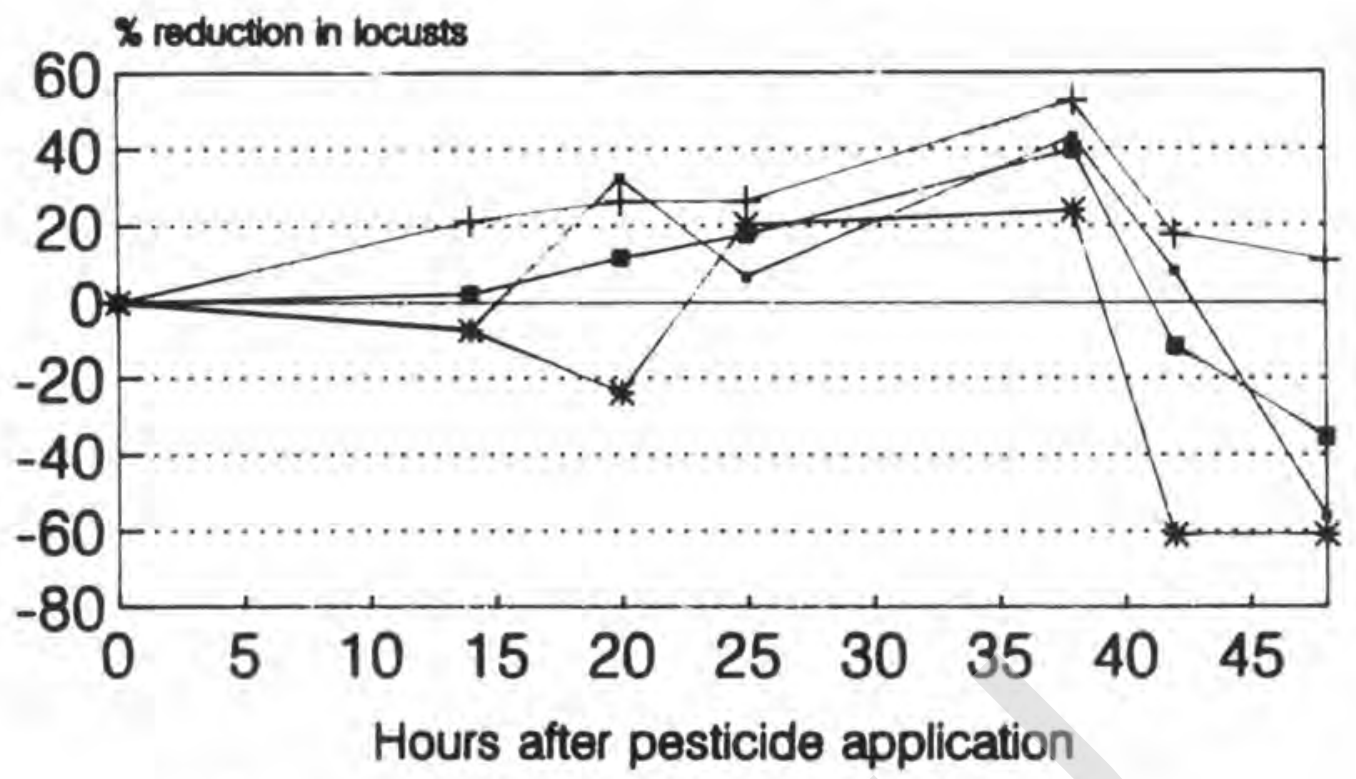

$\rightarrow$ Plot $5+$ Plot $16 *$ Plot $25 \rightarrow$ Mean

Doseges: 187 o a.t/ha

\section{Fig. 17c BHC Ultra Low Dosage}

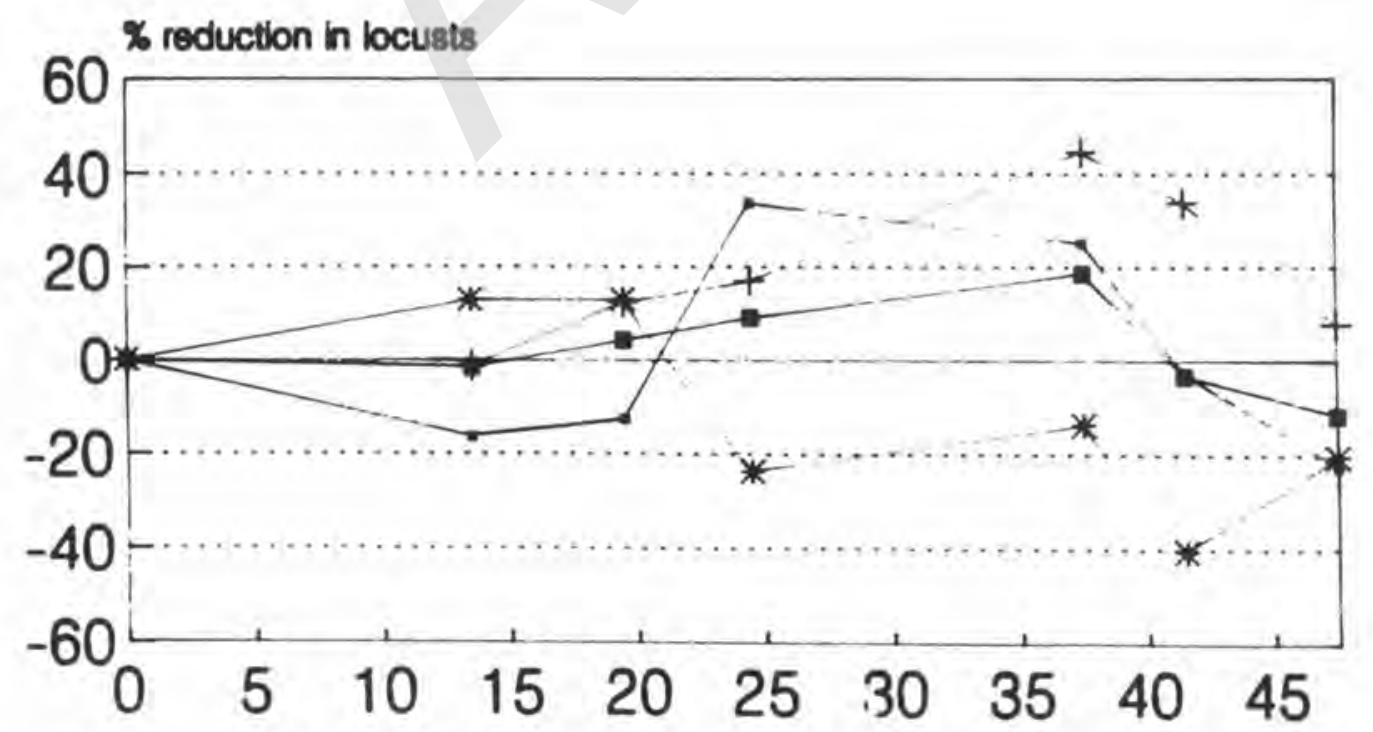

Hours after pesticide application 


\subsubsection{Pesticide efficacy}

Figs. 16 and 17 give the percentages of reduction in locust numbers after spraying with various dosages of Decis and dusting with BHC respectively. The percentages are calculated from the average numbers during the three days of counting before spraying. The curves show results from each of the three plots within each treatment block, and the dotted lines the averages of these three replicates. The normal dosage of Decis, i.e. 11.2 $16.2 \mathrm{~g} \mathrm{a}$.i./ha applied as the pure Decis with 2.2 to $3.2 \mathrm{l} / \mathrm{ha}$ gave a maximum average reduction of $99.5 \% 24 \mathrm{hrs}$ after spraying (Fig. $16 \mathrm{a}$ ). The low dosage of $1.8-3.1 \mathrm{~g}$ a.i./ha applied as $1: 1$ mixture with mustard seed oil applied in $0.7-1.21$ /ha gave a maximum average reduction of $96.1 \% 22$ hours after spraying (Fig. 16 b). The lowest dosage, $1.3-1.6 \mathrm{~g}$ a.i./ha applied as 1 part Decis to 2 parts mustard seed oil in $0.8-0.8$ $\mathrm{l} / \mathrm{h}$ gave a maximum average reduction of $79.4 \%$ reduction 15 hours after spraying (Fig. $16 \mathrm{c})$. Recolonization of the plots was hardly visible in the normal dosage plots, somewhat higher in the low dosage plots, and quite rapid in the lowest dosage plots.

Concerning the BHC treatments, the highest dosage tested, $1.1 \mathrm{~kg}$ a.i./ha, which is less than half of the recommended $2.4 \mathrm{~kg}$ a.i./ha gave a maximum average reduction of $80.5 \% 256$ hrs after dusting, with little recolonization of the plots (Fig. 17 a). The two lowest dosages however, based on the recommended PRIFAS dosages (cfr. sect. 3.4) gave a very weak and slow effect (Fig. 17 b,c).

The control plots (Fig. 18) varied somewhat in numbers, but the averages were quite stable, although a slight

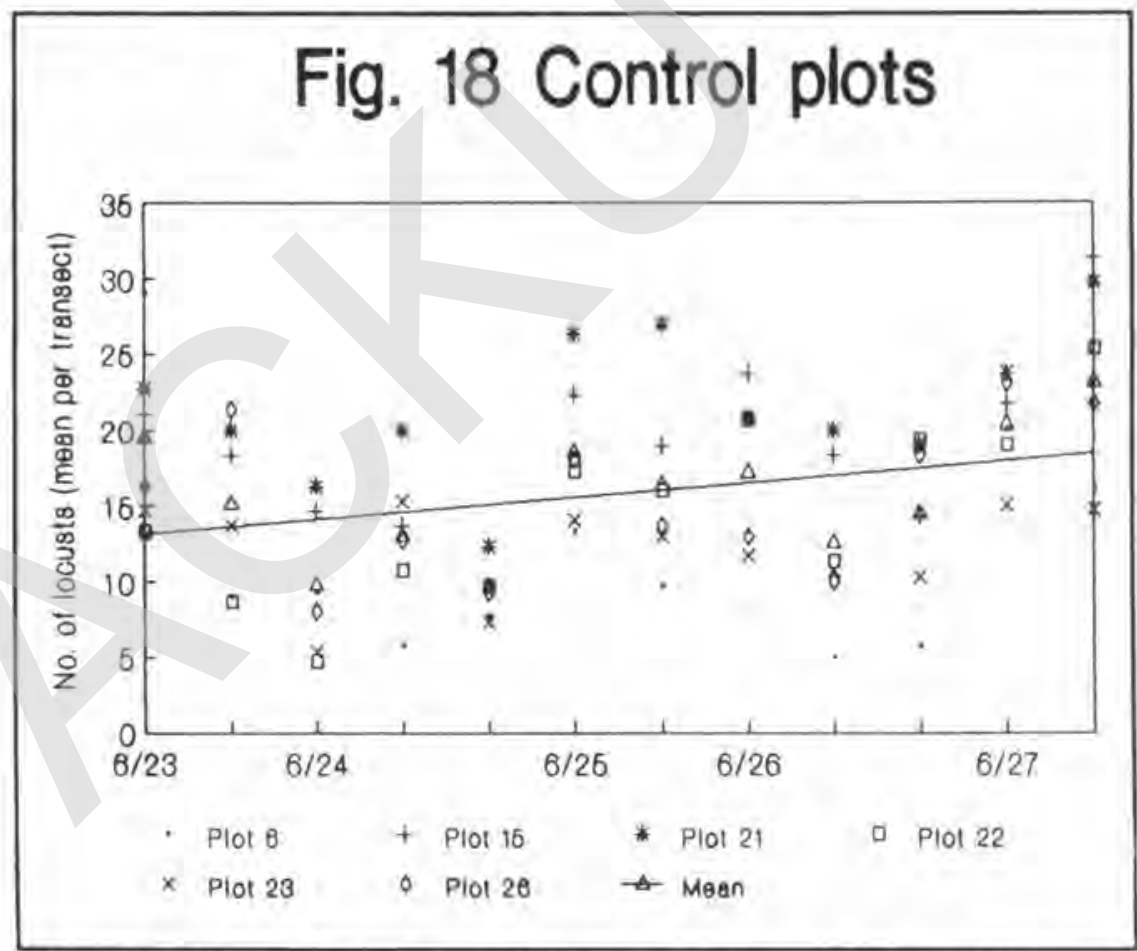

Figur 18. Mean locust number per transect in the control plots during the study. $Y=13.2+0.0456 \times$ (as hours), $\mathrm{p}=0.025, \mathrm{r}^{2}=0.07$. increase in numbers was seen toward the end of the study. This increase could be due to warmer wheather conditions which appeared during the last days of this study, making the locusts more active and thus giving the impression of larger numbers. A compensation for this phenomen in the treated plots would give a picture of slower recolonization. Because the increasing trend is slight and the very low $\mathrm{r}^{2}$-value (cfr. Fig. 18), it is decided not to 
compensate for this. The trend in the control plots can be looked at as a "safety margin" in the estimates of the recommended dosage.

\subsection{Discussion}

The purpose of the atomizer is to produce a narrow spectrum of pesticide droplets, preferentially between 70 and $110 \mu \mathrm{m}$ diameter, but the largest number of droplets usually less than $60 \mu \mathrm{m}$. Droplets less than $70 \mu \mathrm{m}$ are less affected by gravity and more by the characteristic of wind and the surfaces to be impacted (Symmons 1991). Drifting small sroplest are collected more efficiently by hairy than smooth surfaces (Matthews 1977). At $20^{\circ} \mathrm{C}$, droplets of $50 \mu \mathrm{m}$ diameter with specific gravity of 1 , use 69 seconds to fall $5 \mathrm{~m}$ in still air (Symmons 1991). Small droplets can drift over vast distances and even distant areas may risk contamination by drifting chemicals. We can not completly rule out the possibility of offdrift contamination by drifting chemicals in our study. However, we can not see any sign of such contaminition from the results.

Fig. 19 shows the dose-response relationship of Decis. We can see the "flat" dose-respons for dosages over c. $3 \mathrm{~g}$ a.i./ha, i.e. a 5 -fold increase in dosages up to $15 \mathrm{~g}$ a.i./ha provides only a slight increase in response. Higher dosages will only give a minimal increase in locust reduction.

This study shows that $3 \mathrm{~g}$ a.i./ha of Decis applied as 1:1 mixture with mustard seed oil in a total quantity of approximately $11 /$ ha using ULV hand sprayers give a satisfactory reduction in numbers of the Moroccan locust. This quantity is $1 / 4$ to $1 / 5$ of the recommended doosage. In fact, the sales company recommended $20 \mathrm{~g}$ a.i./ha (NCA, pers. comm.). It is thus obvious that the Decis, which intially appeared more

expensive than other pesticides considered, indeed would be a cheaper alternative. As pyrethroids in general, it will probably be among the environmentally safest pesticides, and among those least toxic to humans, cfr. chapter 6 . It thus seems to be a good alternative for future locust operations.

\section{Dosage relation for Deltamethrin} dosage : max. locust reduction

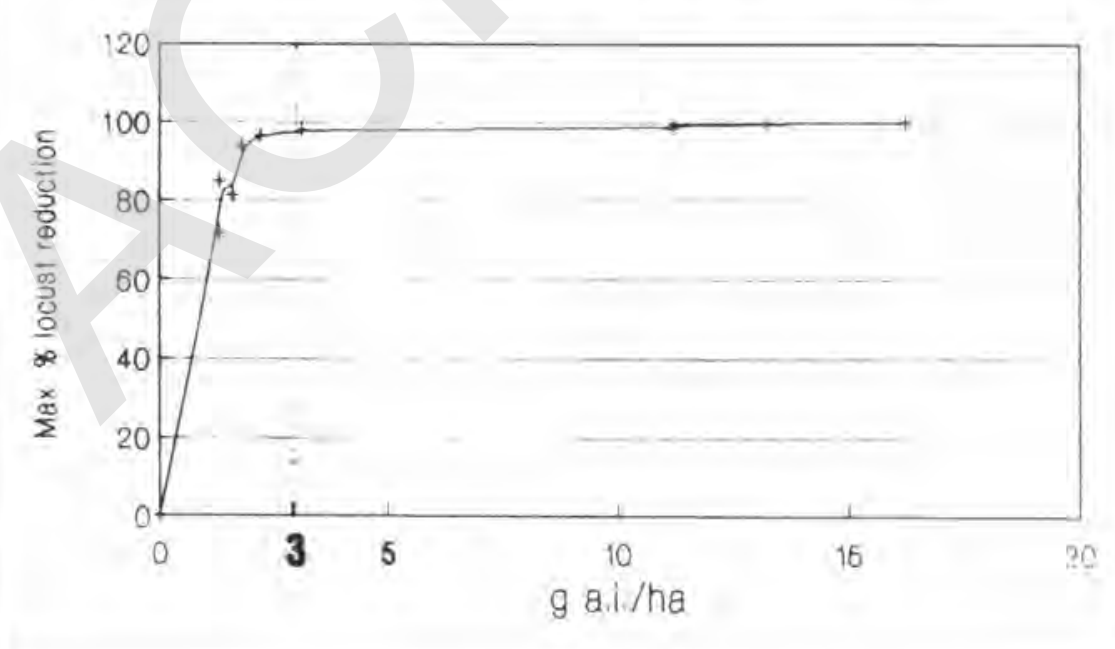

Figur 19. Dose-respons relation for Deltamethrin (=Decis). Note the flat curve for dosages over $3 \mathrm{~g}$ a.i./ha. 
Further studies with Decis should be done. It may well happen that the mixing with mustard oil is obsolute. The purpose of the oil mixture is to increase the droplet numbers, thus securing a more dense coverage of the pesticide in the vegetation and the locusts directly. Although the Moroccan locust prefer areas with a low vegetation, it may inhabit areas with somewhat higher vegetation than in our study plots. This may increase the need for more droplets. Only future tests can give the answer. Similarly, the lowest Decis dosage tested by us, 1.3 to $1.6 \mathrm{~g}$ a.i./ha, which gave a maximum of $80 \%$ reduction, might have been more effective if the droplet numbers were increased to for exampel 1.5 or 2 $1 /$ ha. More droplets would distribute the pesticide even more evenly over the area. In Canada dosages of Decis as low as $2 \mathrm{~g}$ a.i./ha have been found to be give efficient grasshopper control (Johnsen \& Hill 1987).

Concerning the BHC experiments, we can at present not recommend any drastic reduction in the amount to be used. We have no good explanition on the enormous difference between the low PRIFAS dosage ( $160 \mathrm{~g}$ a.i./ha) and the dosages of BHC necessary to kill locusts in Afghanistan (2.4 kg a.i./ha). There is no reports on pesticide resistance in field studies of locusts. However, the high dosages of BHC necessary in Afghanistan indicate that the locusts have built up resistance, but other explanations can also be possible. 


\section{6: Toxicology of Decis and BHC}

\subsection{BHC}

Common name: lindane

Chemical names: $1 \alpha, 2 \alpha, 3 \beta, 4 \alpha, 5 \alpha, 6 \beta$-hexachlorocyclohexane

Other names: $\gamma$-HCH, $\gamma$-BHC, $\gamma$-benzene, Hexachloride, $\gamma$-HKhTsH ('USSR')

Trade names: Gammexane (ICI), Gammalin (ICI), Inexit (Celamerck), Agronexa

(Celamerck), Exagama (Rhone-Poulenc), Gallogama (Rhone-Poulenc), Lindafor (Rhone-

Poulenc), Lindagranox (Rhone-Poulenc), Lindaterra (Rhone-Poulenc), Lindamul (Rhone-

Poulenc), Isotox (Chevron), Gamaphex, Gammex, Linox, Lindan, Novigam, Silvanol, 666

(Dk), hexachlor (S), Aparasin, Ben-Hex, Bore-kil, Gammexane, Gexane, Jacutin, Kwell, Lindatox, Lorexane, Streunex, Tri-6 and Quellada.

Manufacturers: ICI, Rhone-Poulenc, Boehringer, Celamarck, Drexel, Inguinosa,

Chevron and Chemie Linz.

Sources: Roy. Soc. of Chem. (1990) and Hayes (1990).

The name $\mathrm{BHC}$ is in common use in the aid organisations and United Nations Developing Program (UNDP) working in Afghanistan. The eight isomers of $\mathrm{BHC}$ is shown in Fig. 21. According to the World Health Organisation (WHO b) the term lindane should be used only for products containing more than $99 \%$ gamma-BHC. Techinical-grade BHC consists of $65-70 \% \alpha-\mathrm{BHC}, 7-10 \%$ B-BHC, $14-15 \%$ $\gamma$-BHC and about $10 \%$ of other isomers and compounds (WHO 1990 b). Cfr. chapter 5.1 .4 for content of the different isomers in our study.<smiles>ClC1C(Cl)C(Cl)C(Cl)C(Cl)C1Cl</smiles>

Figur 20. Chemical structure of BHC (Roy. Soc. of Chem. 1990).

In some processes for manufacturing BHC, low levels of dioxin may be formed (US Environmental Protection Agency, 1985, cited in WHO 1990 b). It is reason to believe that the Russian BHC is not pure $\gamma$-BHC (lindane), but techinical BHC. WHO recommends that lindane (e.g. $>99 \% \gamma$-BHC) must be used instead of technical BHC, in order to minimize pollution (WHO 1990 b).

BHC belongs to the chemical family organoclorine, the chemical structure is shown in Fig. 20. Many of them are old insectides and have a reputation of being environmental harmful because of their slow degredation and bioaccumalation. BHC was discovered as an insecticide in 1942 (Hayes 1990) and has been used as a broad-spectrum insecticide since the early 1950s (WHO 1990 b). It has been used in control of maleria and other vector-borne diseases, grasshoppers, cotton insects, rice insects, wireworms and other soil pests, households insects and treatments of poultry and livestock (Hayes 1990). The use of $\mathrm{BHC}$ on a number of crops was never practical because the technical mixture imparts to the food a marked off-flavor that is apparent at once or only after the food is cooked (Hayes 1990).

As to the 8 BHC-isomers, only for $\alpha-, \beta-$, and gamma-BHC there is sufficient 
information on the occurrence and the effects to asess the risks (UNEP 1990). The risks presented by the other isomers are not estimated to be greater than those related to $\alpha$-, $B-$, and $\gamma$-BHC because of the exposure levels are lower (UNEP 1990).

Toxcity: $\mathrm{BHC}$ is higly toxic to insects, aquatic life and mammals (Kemikalieinspektionen 1989). The toxcity to fish is high, LC50 (lethal consentration which kills $50 \%$ of the fish) after 96 hours is as low as $0,002 \mathrm{mg} / 1$ for Salmo trutta (Macek \& McAllister 1970).

Acute oral LD50 (consentration which kills $50 \%$ of the test animals) for rats $88-125 \mathrm{mg} / \mathrm{kg}$, mice $59-246 \mathrm{mg} / \mathrm{kg}$. Young animals are especially sensitive. Skin and eye irritant. In 2-year feeding trials, no-effect level for rats was $25 \mathrm{mg} / \mathrm{kg}$ diet, and for dogs 50 $\mathrm{mg} / \mathrm{kg}$ diet (Roy. Soc. of Chem. 1990).

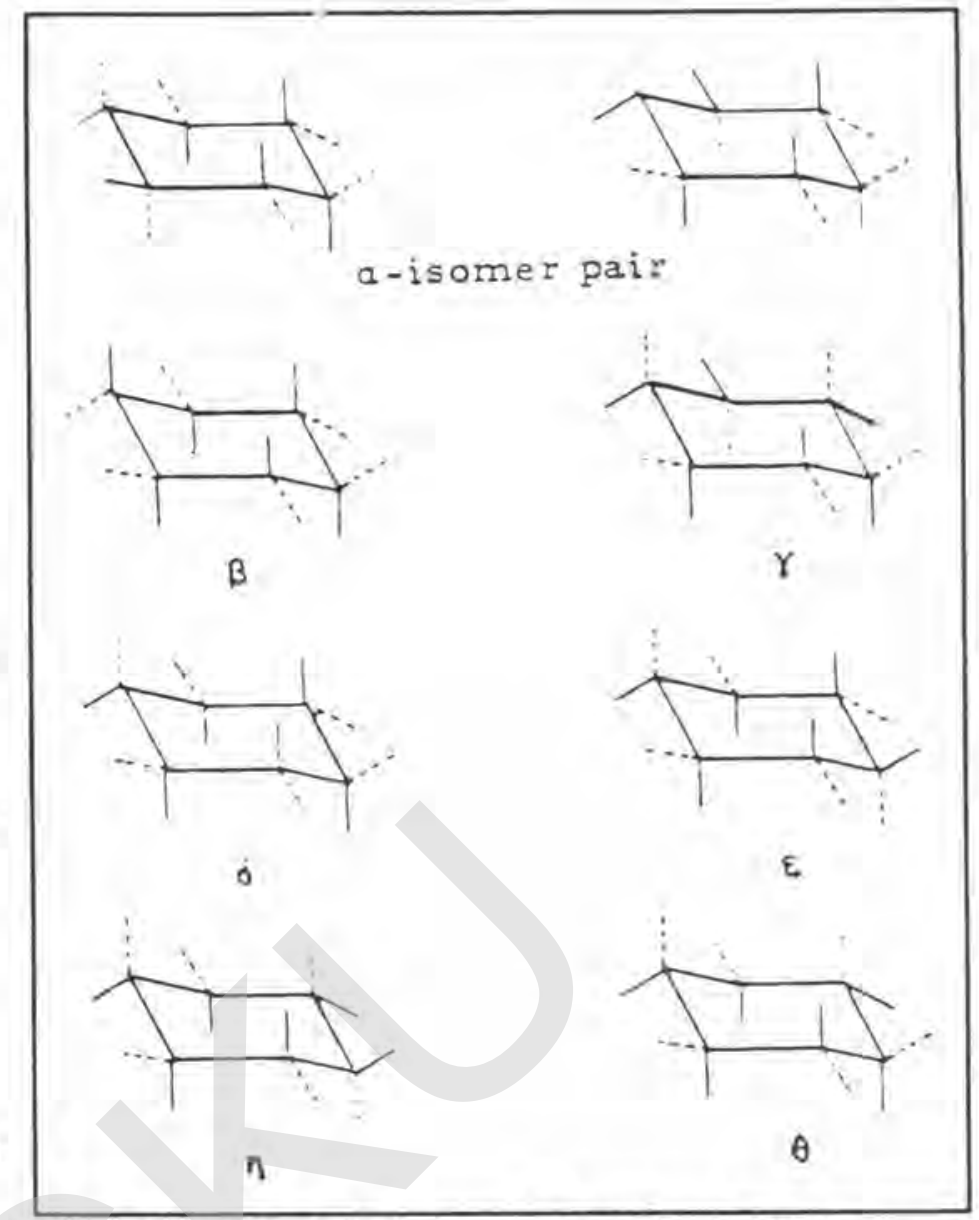

Figur 21 The eight isomers of BHC. Solid line indicate chlorine, and dashed line indicate hydrogen (After Hayes 1990).

In rats, the acute toxicity of the isomers of BHC decreases in the order $\gamma>\alpha>\delta>B$. However, the toxicity of repeated doses decreases in order $\beta>\alpha>\gamma>\delta$. The degree of long-term toxicity of the different isomers is directly related to their storage and inversely related to their rate of metabolism (Hayes 1990).

BHC poisoning in man may cause faintness, dizziness, headache, malaise, staggering gait, incoordination of the hands, parathesias (especially of the fingers and toes), collapse, convulsions, screaming, foaming at the mouth, biting of the tongue, nausea, vomiting, a slight fever, unconscious, retrograde amnesia and in severly poisoned persons; death (Hayes 1990).

According to toxicolog Dr. Allistair Hay at University of Leeds BHC may increase the chances of the blood disease aplastic anemia (Tystad 1992). This is supported by many other studies, but in contrary to some other studies (Hayes 1990).

The toxicity of BHC increase some when protein constitutes less than $9 \%$ of the diet (Hayes 1990). 
Mutagen and carcinogenic effect: BHC cause cromosone-changes and break of cromatides. Sufficent evidence for carcinogenic effect on mice (WHO $1990 \mathrm{~b}$ ). The $\alpha-$ isomer is more tumorigenic than the other BHC-isomers (Hayes 1990). No mutagenic effect found in tests with bacteria, yeast or Drosophila (UNEP 1989). We find $\gamma$-BHC on the Norwegian "cancer list" (Arbeidstilsynet et al.), and also mentioned as cancerogenic in the Safechem data sheet (Tero Safe A/S 1989).

Teratogenic and reproductive effects: According to WHO (1990 b) BHC showed no teratogenic effect in mice, rats, dogs and pigs. However, some studies have reported considerable reduction of fecundity and litter size in rats given $10 \mathrm{mg} \gamma$-BHC per $\mathrm{kg}$ bodyweight for 138 days, and another report told about reproductive effects even in very low dosages like $0.5 \mathrm{mg} / \mathrm{kg} /$ day (Hayes 1990).

Degredation: BHC is stable to light, air, heat, carbon dioxide and strong acids. Dehydroclorinates in the presence of alkali or on prolonged exposure to heat. it is incompatible with strong bases and powdered metals such as iron, zinc and aluminium, and with oxidizing agents; can undergo oxidiation when in contact with ozone (WHO 1990 b).

During degredation the $\gamma$-isomer can transform to $\alpha$ - and $\beta$-BHC, which are more persistent than the $\gamma$-isomer. $B$-BHC is the most stable, over 30 times more $B$ than $\gamma$ BHC is stored in the body at equivalent dosage levels (Hayes 1990). This explains why the $B$-isomer is more toxic when administered repeatedly even though the $\gamma$-isomer is more toxic when given as a single dose (Hayes 1990).

During degredation less-clorinated, unsaturated metabolites, such as pentachlorocyclohexane $(\mathrm{PCCH})$ are formed. In addition to $\mathrm{PHHC}, 1,2,4$-trichlorobenzene and isomeric trichlorphenols are formed as metabolites, and are excreted as the glucuronic acid derivates. In rats, following oral intake, $\gamma$-BHC is found in milk, body fat and kidneys, but rapid elimination occurs (Roy. Soc of Chem. 1990). $\gamma$-BHC is exreted more efficiently than the B-isomer (Hayes 1990).

Many of the metabolites much be regarded as harmful. Metabolites of special interest are di-, tri-, tetra,- penta- and hexachlorbenzene (Kemikalieinspektionen 1989). BHC is less stable than other chlorinated hydrocarbons like DDT, aldrin and dieldrin (Schanke 1992), but more stable than endrin and methoxychlor (Hayes 1990).

Occurence in environment: BHC is circulating in the environment and is present in food chain. It is spread all over the biosphere in low concentrations and can be detected in air, water, soil, sediment, aquatic and terrestrial organisms and food (WHO 1990 b). BHC is found for instance in rainwater in Germany at 0.05-0.4 $\mu \mathrm{g} / 1$ (COST 1984) and air in Sweden at $<1 \mathrm{ng} / \mathrm{m} 3$ (Bidleman et al. 1987). The high vapour pressure and low water solubility make BHC very suitable for air transport (Øhme 1991). 
Table 8. The ecotoxicological acceptable level of BHC according to UNEP (1989):

\begin{tabular}{llll}
\hline & $\alpha-\mathrm{BHC}$ & $\mathrm{B}-\mathrm{BHC}$ & $\gamma-\mathrm{BHC}$ \\
Freshwater environment & $5 \mu \mathrm{g} / \mathrm{l}$ & $1 \mu \mathrm{g} / \mathrm{l}$ & $0.1 \mu \mathrm{g} / \mathrm{I}$ \\
Coastal waters & $1 \mu \mathrm{g} / \mathrm{l}$ & & $0.002 \mu \mathrm{g} / 1$ \\
Soil & & & $10 \mu \mathrm{g} / \mathrm{kg}$ \\
\hline
\end{tabular}

In e. g. the Netherlands the acceptable levels (Table 8) are exceeded in coastal waters, and locally in fresh water and soil (UNEP 1989). The isomer $\gamma$-BHC can be transformed to the more stable $\alpha$-BHC by sunlight (Øhme 1991). The ratio $\alpha / \gamma-$ BHC in air change from about 3:1 in areas where pure $\gamma$-BHC is applied, to between 10:1 and 50:1 in remote areas like the Artic (Øhme 1991). This indicate that the isomer transformation actually happens in the environment.

There is no published information about the level of BHC in the Afghan ecosystems. BHC residues are found in Indian birds, with higher consentration in predatory birds Black kite, Milvus migrans and Oriental white-backed vulture Gyps bengalensis than nonpredatory bird like Rock pigeon Columba livia and Cattle egret Bubulcus ibis (Kaphalia et al, 1981).

BHC shows a medium high bioaccumulation factor. In laboratory conditions the consentration factor ranged from 10 up to 6000 , under field condition, the bioconsentration factor ranged from 10 to 2600 (WHO 1990 b).

BHC is regarded as harmful to the environment, and it is banned in Sweden and Japan. In Norway the strategy is to phase out this pesticide (Scanhke, in letter 1992). Steedman (1988) regards BHC as the second most harmful insecticide of 7 in common use against locust, only "beaten" by the organocloride dieldrin. 


\subsection{Deltamethrin}

Deltamethrin is also known under several names (Roy. Soc. of Chem. 1990):

Common name: deltamethrine

Chemical names: (1R-(1 $\left.\left.\alpha\left(\mathrm{S}^{*}\right), 3 \alpha\right)\right)$-cyano(3-phenoxyphenyl)methyl 3-(2,2dibromoethenyl)-2,2-dimethyl-cyclopropanecarboxylate (CA)

(S)- $\alpha$-cyano-3-phenoxybenzyl (1R,3R)-3-(2,2-dibromethenyl)-2,2-dimethylcyclopropanecarboxylate (IUPAC)

Trade names: Decis (Roussel Uclaf, Hoechst, Procida); K-Othrin (Roussel Uclaf, Hoecht, Procida); Butoss (Roussel Uclaf); RU 22974 (Roussel Uclaf); Cislin (Wellcome);

Crackdown (Wellcome).

Decis is manufactured by Roussel Uclaf and belongs to the chemical family pyretroids. It was first marketed in 1977. In 1987 , the world production was 250 tonnes (WHO 1990 a). The chemical structure is shown in Figure 22.

Deltamethrin occurs in 6 stereoisomers, see Fig. 23.

The vapour pressure is very low, $0.002 \mathrm{mPa}$ at $25^{\circ} \mathrm{C}$. The pesticide is extremely stable on exposure to air. Under UV irradiation and in sunlight, a cis-trans isomerization, splitting of the ester bound, and loss of bromine occurs. More stable in acidic media than in alkaline media.

Toxicity: Like BHC, deltamethrin is higly toxic for fish, the LC50 ranging between 0.4 and $2.0 \mu \mathrm{g} / \mathrm{l}$. It is also higly toxic for aquatic invertebrates, but because of the rapid degredation the kill is

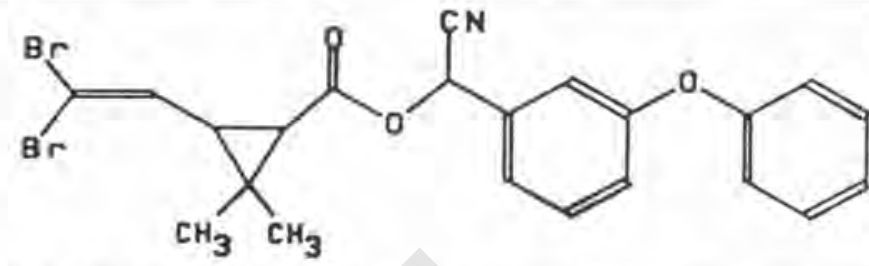

Figur 22. The chemical structure of deltamethrin (Roy. Soc. of Chem. 1990) usually compensated rapidly. The toxicity of deltamethrin for birds and mammals is very low (WHO 1990 a). 
No mutagenic effect is discovered.It is non-irritating to skin, and only a mild eye irritant (Roy. Soc. of Chem. 1990).

He et al.(1989) rewieved 325 cases of deltamethrin intoxication from the Chinese medical literature. Common findings included paraesthesia, particularly involving the face, dizziness, headache, neusea, anorexia and fatigue. Less common findings includes chest tightness, palpitations, blurred vision, increased sweating and low-grade fever. Muscular fasciculations, convulsions and coma were reported in some of the more severly poisoned cases. Two deaths from convulsions were reported (He et al. 1989).

Deltamethrin was tested for carcinogenicity in one experiment in mice and in one experiment in rats by oral administration. In mice, no increase in tumour incidence was seen. In rats, a statistically significant increase in the incidence of unspecified thyroid adenomas was observed in low-dose males and high-dose females. No data for carcinogenicity in humans are available. WHO conclude that there is inadequate evidence for the carcinogenicity of deltamethrin in experimental animals, and deltamethrin is not classifable as to its carcinogenicity to humans (WHO 1991).

Degredation: The degradation in the environment is fast within 1-2 weeks. In rats we know that after oral administration, elimination occurs within 2-4 days. The phenyl ring is hydroxylated, the ester boynd hydrolyzed, and the acid moiety is eliminated as the glucuronide and glycine conjugate (Roy. Soc. of Chem. 1990). 


\section{Chapter 7: Prospects of alternatives to chemical control}

\subsection{The need for alternatives}

Today, 30 years after Rachel Carson wrote her famous book; Silent Spring (Carson 1962), the main method of locust control is still solely the chemical one. Carson's book started the debate on this issue.

A large number of humans are poisoned by agricultural chemicals every year. Figures of 1 million affected people per year are quoted, and 40000 deaths assumed by UNEP (1987). Bull (1982) quoted 750000 cases in 1981 with 13800 deaths. Most of these cases are from Third world countries, in spite of their lower pesticide use.

According to Everts (1990) the ecotoxicological risk of the use of pesticides in arid areas is virtually unknown. Our $90 \%$ of our knowledge on the hazards of insecticides concerns temperate climatic zones, both with respect to the fate and behaviour of chemical compounds and with respect to ecological impact. The results, however, so far indicate that chemical insecticides cause a strong effect on terrestrial invertebrates, a devastating effect on aquatic invertebrates and an effect on birds, both with respect to their numbers and diet (Everts 1990).

Non-target organisms like different species of insects, myriapods and spiders have an increased mortality after spraying with incecticides (Ottesen et al, 1990, Johannesen 1991). The negative effect of pesticides on birds and especially raptors have been known for a long time. Other groups of animals vulnerable to pesticides are mammals, reptils, fish, amfibier, fish and plankton.

The pesticide trade is continually increasing. Between 1972 and 1985 , imports of pesticides increased by 261 percent in Asia (Postel 1987). According to Dinham (1991) the World Health Organization (WHO) expects pesticide use to double in the developing countries in period 1989 to 1999.

\subsection{The "zero-alternative"}

Locusts are fought because they cause food loss to humans. Spraying programs cost a lot of money. This money can also be spent on food aid. The aid organisations have a choice between providing food aid or controlling locusts. Locust damage is sporadic and local, although very important for those affected. Food aid is an alternative but would require storages of food for plague periods, and an adequate warning system for effectuating rapid food aid.

For the Sahelian region Bie et al. (1989) state that one may wonder whether doubts about the wisdom of food aid have overshadowed the doubts on the wisdom of insecticides against locusts. The same argument can be used also for the situation in Afghanistan, 
although the country is in a special position with civil war and poor communication systems and infrastructure. It is beyond the aim of this thesis to discuss all the pros and cons of food aid as an alternative to pesticide spraying, but this aspect ought to be considered by the aid organisations.

\subsection{Biological control}

Natural enemies of locusts exist among viruses, bacteria, fungi, protozoa, insects, spiders, nematodes, lizards, birds and mammals. The natural enemies may be pathogens, parasites or predators.

In most generations of locusts mortality due to natural enemies rarely exceeds $10 \%$ (Chapman, 1976; Farrow, 1988). However, if successive generations breed on the same site, the mortality due to natural enemies may increase with more than $30 \%$ of the immature stages and reduce overall survival to less than 0,001\% (Stover \& Greathead, 1969).

Vertebrates predate mainly on nymphs and adults of locusts. The Rosy Starling (=Rosy Pastor), (Sturnus roseus) known as Saach (Fig. 24) in Afghanistan is known by the Afghans as an important predator on locusts. It can locally be present in high numbers especially during migration. Ali (1985) estimated close on half a million Rosy Starling during the first week of May 1935 at the Danaghori plain in North Afghanistan. The Rosy Starling is considered as beneficial to agriculture and the Afghans do not molelt them even when little other "lawful meat" is safe from the pot (Ali 1985). Flocks will actively search out and feed upon hatching locusts. As long ago as the 1940s the British Indian Government felt it necessary to pass special legislation to protect the species because it was often netted for food during its spring migration (Roberts 1991).

The Common Mynah Acriodotheres tristis (Fig. 25) is a common bird in Afghanistan (Paludan 1959) and a predator on locusts (Roberts 1991). We often observed this species during our stay in Badakshan (Sondbø \& Ottesen 1991). The successful introduction of this bird to Maurtitius in 1762 to control Red locust Nomadacris septemfasciata is one the earliest recorded exampel on biological control (Bie et al. 1989). Also other Afghan bird like Roller (Coracias garrulus), larks (Alaudidae), wagtails (Motacillidae), wheatears (Oenanthidae), thrushes (Turdidae), shrikes (Laniidae), storks (Ciconiidae), kites and eagles

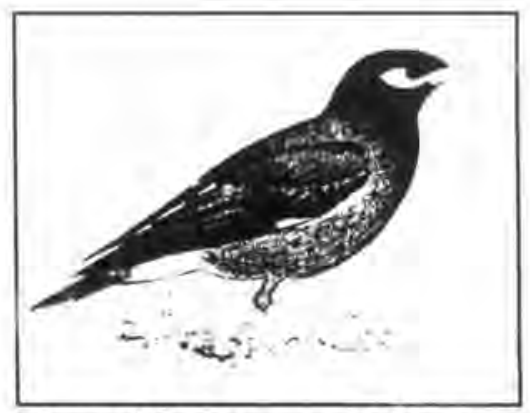

Figur 25. Common Mynah (Hollom et al.1988) (Acipitridae) have been reported feeding on locusts. The 
birds are attracted by the locusts and a single individual can consume thousands of them (Grant 1989).

Lizards (Lacerta sp.) are also recorded as predators on locusts. Seven species of lizards are reported preying on acridids, including Desert locust, in South-western Afghanistan in 1970-74 (Chandra \& Sing 1981).

Invertebrates attack mainly eggs and larvaes of the locusts. Egg predators include various insect larvae, especially those of the calliphorid fly Stomorhina lunata and the beetle Trox procerus, both of which are largely confined to gregarious populations. Parasites of the Desert locust include dipterous larvae ( Sacophagidae e.g. Blaesoxipha filipjevi; Nemestrinidae e.g. Symmictus costatus and Tachinidae) and nematode larvae (Mermithidae). Few egg parasites have been recorded although the larva of parasitic wasps (Scelionidae) is common in pods of locusts from other habitats (Farrow 1988). The robber-fly Machimus annulipes is found to be important predator on young larvaes of Italian locust in the Rostov distict, USSR (Kurkina 1979). The sarcohphagid Blaesoxipha litoralis is parasitic on Italian locust, which is the only known host (Leonide \& Leonide 1977). The protozoan Malamceba locustae was found in 70 percent of Italian locust in Italy (Lipa \& Desco 1988).

Fungi such as Beauveria and Entomophthera sp. normally keep Italian locust in check in Italia (De Giovanni et al 1986). The entomophagus fungus Metarhizium anisopliae is reported on Desert locust, and have destroyed a gregarious population during humid conditions (Farrow 1988). The species is presently used on a wide scale in Brazil to control the Sugarcane spittle bug (Mahanarva posticata). Metarzium flavoviride has been successfully tested against the Rice brown planthopper (Nilaparvata lugens) in the Phillipines, and recent laboratory studies have demonstrated that it is highly virulent against locusts (Goettel 1992).

Entomophaga grylli and related species is an obligate grasshopper pathogen responsible for numerous epizootics in grasshoppers world-wide. It is regarded as the key factor regulating many grasshopper populations, often reducing populations to below economic thresholds. Another promising fungi is Beuveria bassiana which have a very wide host range with over 700 insect species. There are several records ot $B$. bassina infecting grasshoppers and it has been documented as the cause of epizootic in a swarm of Red locust (Goettel 1992).

Viruses: A entomopox virus was discovered in a population of moribund individuals of gregarious Desert locust in Yemen (Purrini \& Rohde 1988).

No natural enemies appear to exploit locusts as their sole host. They attack a wide range of other acridoids when these are available (Farrow 1988). 
Locust pheromones: Pheromons are chemicals which the organisms utilise to communicate with members of their own species. Pheromons elicit an immediate behavioural response or stimulate long term physiological changes (Isman 1990). Different pheromons which possibly can be used in biological control are:

1) Gregarisation pheromone, initiates crowding and aggregation of solitarious locust and hoppers into swarms in adult life

2) Solitarisation pheromone, promotes some solitary characteristics and may be useful in dispersing locusts.

3) Maturation pheromone, accelerates and synchronizes sexual maturation in both sexes.

4) Oviposition pheromone, aggregates females of both phases to a common oviposition sites and stimulates egg-laying or attracts females to substances previously used by egg-laying locusts.

5) Sex pheromone, stimulates the finding of sexual partners, courtship and copulation. However, there is no clear evidence that locusts use any sex pheromone and the relationship between pheromones, juvenile hormone and sexual behaviour is not clear

6) Maturation-inhibiting pheromone, inhibits or delays sexual maturity of locusts (Ferenz 1990).

This pheromones have to be identified and massproduced in an economically acceptable way, before they can be used in biological control.

Locust hormones: Juvenile hormone regulates growth, development and reproduction. It also promotes solitary phase characteristics. Juvenile hormone analogues are part of the defensive strategy of some plants against insects. Immature locusts feeding on such plants suffer development derangement and never mature while the aduls become unable to gregarise or transform to solitary and non migratory phase. Anti-juvenile hormones are also components of plant definsive strategy against insects. Nymphs fed on these plants undergo precocious metamorphosis into diminutive sterile adults. Normal adults may become sterile of these hormones (Tsegaye et al. 1990).

Trap plants Host plants compounds may act as short range attractants or feeding stimulants which could be incorporated into feeding baits laced with toxicants, pathogens or growth regulators to increase efficiency and minimize non-target toxicity. Other plant compounds may repel insects from certain plants or deter feeding, and may therfore be used to protect crop plants. 


\subsection{State of development}

The protozoan, Nosema locustae is used against locusts in the USA and Canada. It is marketed as Nolo bait. It infests a wide range of grasshoppers and locusts, including the Desert locust. This protozoan is already in use against sedentary grasshoppers in USA with great efficiency (Henry \& Onsager 1982). It could prove useful as a major component of integrated desert locust managment strategy because this protzoan is resident in the solitary phase within its recession breeding sites (Odhiambo 1988).

The most promising of recently developed botanical insecticides is neem, an extract of the Neem tree Azadirachta indica. It inhibits feeding behaviour and also severely disrupts the hormonal and metabolic processes in the insects (Ferenz 1990).

The bacterium Bacillus thuringensis is the most successful microbial pesticide, with annuals sales of over US $\$ 40$ millions (Milner 1992).

Farrow (1988) claim that production of virulent pathogens from excisting benign forms is the only way to provide $<99.9 \%$ kills with biological control agents. At present we have no such biological control agent. Currently viruses offer the best material for engineering, although Bacillus thuringensis is a possibility if it can be induced to attack Acridoids, while Metarhizium anisopliae also offer some potensial (Farrow 1988). Entomophaga grylli have potensial, but at present we have no method to massproduce it economically (Goettel 1992). Metarhizium flavoviride is very promising (Lomer \& Prior 1992).

Economic analysis has indicated that, if succesful, an application rate of $10^{13}$ conidia from Beauveria bassiana per hectar can be competive in price with chemicals currently used for grasshopper control in the USA (Goettel 1992). 


\section{8: Reccomenditions for the NCA project}

\subsection{Generel advice}

The pesticides should only be used by trained personel. The author advises NCA not to support projects that involve use of pesticides by untrained farmers, or projects which aim at subsiding pesticides so that they should be available and affordable in the bazars.

In the long run pesticides should be replaced by biological control. Within a couple of years we will probably have effective biological control agents, and NCA ought to follow the development of biological control. An analyzis of food aid/ insurance schemes as an alternative to spraying should also be considered.

Some observations on the locust campaign in 1991 must be mentioned:

1) We cooperated with the Afghan supervisors and field workers of the Keshim/Jurm locust teams, and we were dependend on their suggestions for finding an area with high numbers of the Moroccan locust for doing experiments. They suggested an area near Darajim in the Keshim valley. This area had a high locust density and was soon going to be sprayed. When arriving in the area, however, the "locusts" we were shown were not the Moroccan locust. They were actually bush crickets (Tettigoniidae) and various harmless grasshoppers. It was soon disclosed that they did not know what the Moroccan locust looked like, and they had no experience with locusts previous to the 1990 training course. During this course, they were not shown the Moroccan locust or given training in systematics. Their booklet showed no good picture of this species. They had just been told it had a white $\mathrm{X}$ on its back. Ottesen made a colour painting of the 3rd stage hopper that is now handed over to the NCA. It could be copied as colour photography or printed as an aid for further training. There is a possibility that the wrong species has been treated in 1991.

2) The locust team was instructed to walk at normal speed (i.e. $60 \mathrm{~m} / \mathrm{min}$ ) and using red nozzle on the Micro ULVA and a swath with of $10 \mathrm{~m}$. They would then get the right dosage of $12.5 \mathrm{~g} \mathrm{a.i./ha.} \mathrm{Our} \mathrm{calculations} \mathrm{and} \mathrm{calibrations} \mathrm{showed} \mathrm{that} \mathrm{they} \mathrm{in} \mathrm{that} \mathrm{case,}$ however, would get aprroximately $3 \mathrm{~g}$ a,i,/ha. They had, however, seen that the locust ( or grasshoppers?) died as expected. This is in accordance with our results with $3 \mathrm{~g}$ a.i./ha. The paradox of our study is that we could tell them to reduce the dosage to $1 / 4$, but continue to spray exactly as they had been doing! Dosage calculations, which are treated closely in the Farsi booklet, was not at all understood by the team.

3) A supervisor told that he had heard that $10 \mathrm{~g}$ a.i./ ha was to be used, but on the barrels it was indicated twice as much, and he had therefore used the amount suggested on the barrels. However, it soon became evident that everything was very obscure, he claimed that there was two different formulations etc, which there was not. The impression of very low qualifications of the locust team was inevitable 
4) The cleaning procedure of the sprayers was not followed. Whether this was due to insufficicient training or carelessness is not known.

5) Comparing the locust problem of the Keshim Valley with that experienced in Africa, it seemed not to be any serious problem during 1991. Some localities, especially at higher altitudes, however seemed to have rather high densities, justifying control. The reason for low locust numbers may the unusually cold winter of 90/91 and late spring in 1991 .

In conclusion, it appears that the training course should be more practical, with field tests, practical calculations and better training in systematics. The booklet in Farsi was translated and generally gave a good impression. Provided that a few corrections and extensions as suggested above are included, combined with practical training, the training should be well suited for the purpose of educating locust teams.

\subsection{Type of pesticide}

I will advise NCA not to use BHC in the spraying campaign, because this pesticide is an environmental hazard. The main reasons are the persistence, bioaccumalation, worldwide distribution in the environment and the toxicity to aquatic life and mammals. Deltametrin (Decis) is a much better alternative from a health and environmental viewpoint.

The dosages recommended ( $3 \mathrm{~g}$ a.i./ha) are rather low, but sufficient with this potent pesticide.

\subsection{Cost-analysis of different consentrations and mixing with vegetable oil}

The reduction of Decis from 12.5 to $3 \mathrm{~g}$ a.i./ha will give approximately $75 \%$ price reduction, as the mustard seed oil which was added to the $3 \mathrm{~g}$ a.i./ ha dosage is cheap compared to the pesticide. However, further saving can possibly be obtained if a concentrated formulations of Decis, like $12.5 \%$ which were tested in Sudan, are mixed inside Afghanistan with mustard seed oil. The 0.5\% decis used in Afghanistan 1991 was voluminous to transport from Pakistan. The cost of transport from the border to the places in question in Badakshan is 5000 Afghanis per seer ( 1 seer $=7 \mathrm{~kg}$ ). The price of Mustard seed oil is $4500 \mathrm{Afghanis/seer.} \mathrm{According} \mathrm{to} \mathrm{local} \mathrm{information,} \mathrm{quantities} \mathrm{like} 1000$ seers of mustard oil would be available from cities of Farkhar, Taloqan and Kunduz.

According to information from the deltamethrin manufactur; Roussel Uclaf, sent the Norwegian importer; Collet Kjemi, Decis 2.5\% ULV formulation is the strongest available. However, technically more consentrated formulations are available only for reformulation in factories. The $2.5 \%$ ULV formulation is 5 times more consentrated than the $0.5 \%$ ULV formulation. The tranport volume an 1 transport costs can be reduced by 80 $\%$ if NCA changes to this formulation when more pesticide has to be sent to Badakshan. 


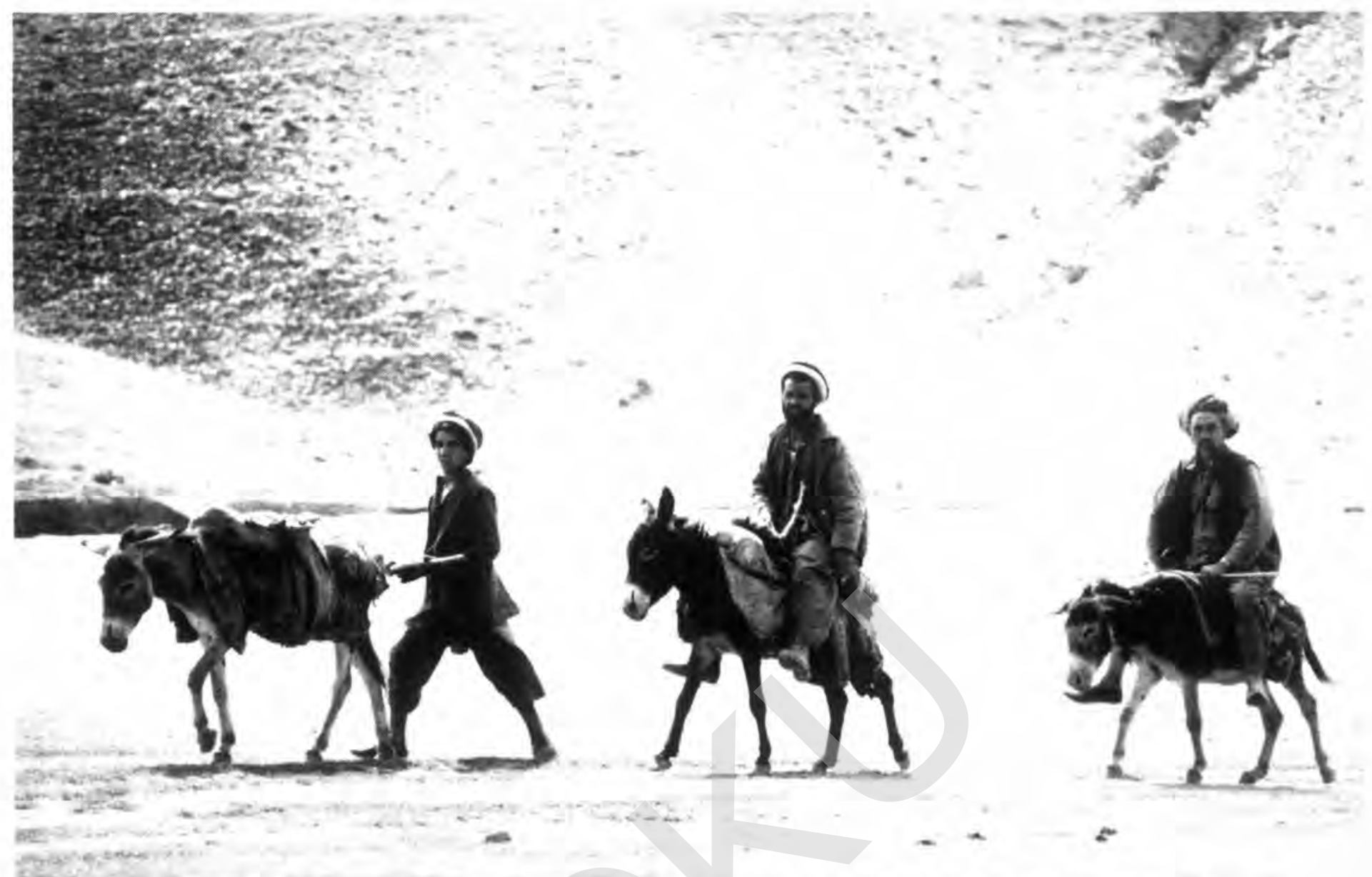

Figur 26 Transport is complicated i Badakshan, donkeys, horses and porters dominate. The pesticides for the spraying campaign in 1991 was transported up to $350 \mathrm{~km}$ on donkeys.

The price per active ingridient is also considerably lower for the more consentrated formulation (Tore Erlandsen, Collet Kjemi, pers. comm.). The price of the $2.5 \%$ ULV formulation in Pakistan has been difficult to get to know. Only the $0.5 \%$ ULV formulation is normally imported by the Pakistanian importer, and he would not give a price before he had an order. The French producer, Rhoussel Uclaf, would not give any price because it would be based on an agreement between them and the Pakistani importer.

To give an idea about possible savings with stronger formulations I can mention the fungicid tiabendazol. The price of $45 \%$ is $357 \mathrm{kr}$ per litre, while the $5 \%$ powder costs $115,-\mathrm{Nkr}$ per $2 \mathrm{~kg}$ during 1992. This means that the price per $\mathrm{kg}$ active ingridient is 793,- Nkr per kg for the consentrated pesticide while the powder cost $1150,-\mathrm{Nkr}$ per $\mathrm{kg}$. The difference is $357,-\mathrm{kr}$ per $\mathrm{kg}$, which is $31 \%$ less for the consentrated formulation.

A change to $2.5 \%$ ULV Decis will mean:

- a $80 \%$ cut in transport costs in Pakistan and Afghanistan.

- perhaps about $30 \%$ cheaper chemicals per active ingridient.

The increased cost of mixing with mustard seed oil is considerably less than will be saved only in transport costs in Afghanistan. 


\section{9: References}

Akinci, A.R. 1987. The reservoir areas, and their characteristics, of the Italian locust (Calliptamus italicus, L.) and the Moroccan locust (Dociostaurus maroccanus, Thunb.), in Bitilis and Siirt Provinces, - Narenciya Arasirma Enstitusa Md. 1987: 351-356.

Ali, S. 1985. The Fall of a Sparrow. - Oxford University Press, Delhi. 265 pp.

Arbeidstilsynet, Direktoratet for brann og eksplosjonsvern, Oljedirektoratet \& Statens forurensningstilsyn 1990. Forskrift om stoffliste. - Fabritius forlag, Oslo. 120 pp.

Bidleman, T.F., Wideqvist, U., Janson, B. \& Söderlund, R. 1987. Organochlorine pesticides and polyclorinated biphenyls in the atmosphere of southern Sweden. Atm. Environ. 21(3):641-654.

Bie, S., Herstad, B., Olafsson, H. \& Sømme, L, 1989. Locust and grasshopper control. A scientific background for Norwegian aid policy, with particular reference to the Sahel. - Norwegian Ministry of Development Cooperation, Oslo. 64 pp.

Bull, D. 1982. A growing problem: Pesticide and the Third World Poor. - Oxfam, Oxford.

Carson, R. 1962. The silent spring. - Houghton Mifflin Co., Boston.

Chandra, H. \& Singh, C. 1981. Some lizards predators of acridids of South-western Afghanistan, - Plant Protection Bulletin, India. 33 (3/4): 153-155.

Chapman, R.F. 1976. A Biology of Locusts. The Institute of Biology's Studies in Biology no.71. - Edward Arnold, London. 67 pp.

Chetyrkina, I.A. 1954. Acridoidea of steppes and deserts of the region of the river Ural. (In Russian). - Trudy zool. Inst. Lenigr, 16: 229-284.

COST 1984. Analysis of Organic Micropolluttants in Water - (COST 64b bis) Commission of the European Communities, 4, 9th edition,

Dinham, B. 1991. FAO and pesticides: Promotion or proscription? - The Ecologist, 21 (2): 61-65.

Everts, J.W. 1990. Methods for monitoring the impact of chemical control of locust and grasshoppers in Africa. - Noragric Occasional Papers Series C, 5: 45 - 54.

Farrow, R. 1988. Prospects for biological control of Desert locust Schistocerca gregaria. - UNDP-meeting, Cairo 1988, 6 pp. 
Farrow, R.A. \& Longstaff, B.C. 1986. Comparison of the annual rates of increase of locusts in relation to the incidence of plagues. - Oikos 46:207-222.

Ferenz, H.G. 1990. Locust control by insect semichemical (pheromons, kairomones, hormones) advantages and health and environmental impacts. - Noragric Occasional Paper Series C, 5: 89-99.

Giovanni, G. de, Pollini, A., Testi, V., Chiusa, B. \& Martininbianco, R. 1986. Grasshopper infestations in Emilia-Romagna. - Informatore Fitopatologico, 36 (6): 17-24.

Goettel, M.S. 1992. Fungal agents for biocontrol. - In: Lomer, C.J. \& Prior, C. (eds), Biological control of locusts of grasshoppers. C.A B International, Oxon. pp. 122-132.

Grant, I.F. 1989. Environmental effects of desert locust control. - Plant protection bulletin. 37 (1): 27-36.

He, F., Wang, S., Liu, L., Chen, S., Zhang, Z. \& Sun, J. 1989. Clinical manifestations and diagnosis of acute pyrethroid poisoning. - Arch. Toxicol. 63: 54-58.

Hollom, P.A.D., Porter, R.F., Christensen, S. \& Willis, I. 1988. Birds of the Middle East and North Africa. - T \& AD Poyser, Calton. 280 pp.

Hayes, W.J. 1990. Pesticides studied in man, Revised edition, - Williams \& Wilkins. Baltimore/London. 672 pp.

IARC 1979. Some halogenated hydrocarbons. Monographs on the Evaluation of the Carcinogenic Risk of Chemicals to Humans, Vol,20, - Internat. Agency Res. Canser, Lyon.

Isman, M.G. 1990. Biorational insecticides and behaviour modifying substances; their possible impacts on the environment and human health.- Noragric Occasional Papers Series C, 5 : 101-110.

Johannessen, B. 1991. Reduced Dosages of Fenitrothion Applied against Grasshoppers (Acrididae) and Short-term Effects on Non-target Arthropods in Mali. - Cand. scient. thesis in ecology, University of Oslo, $54 \mathrm{pp}$.

Johnson, D.L. \& Hill, B.D. 1987. Control of grasshoppers with two formulations of the pyrethroid insecticide deltamethrin. - Research highlights, Lethbridge Researh Station, Agriculture Canada, Alberta,

Kaphalia, B.S., Husain, M.M., Seth, T.D., Kumar, A. \& Murti, C.R.K. 1981. Organocloride pesticide residues in some Indian wild birds. - Pesticides Monitoring Journal, 15 (1): 9-13. 
Kemikalieinspektionen 1989. Miljöfarlige ämnen, exempelliste och vetenskaplig dokumentasjon. - Rapport 10/89, Stockholm. 303 pp.

Kemikalieinspektionen 1990. Deltametrin. - Information sheat. 4 pp.

Key, K.H.L. 1950. A critique on the phase theory of locusts. - Quart. Rev. Biol. 25:363-407.

Krebs, C.J. 1985. Ecology - the experimental analysis of distribution and abundance. 3 th edition. - Happer \& Row, New York. 800 pp.

Kurkina, L.A. 1979. Biology of the robber-fly Machimus annulipes. Entomologicheskoe Obozrenie, 58 (1): 57-63.

Launius-Luong, M.H., Launois, M. \& Rachadi, T. 1988. La lutte chemique contre les criquets du Sahel. Collection Acridologie Operationelle 3. - Ministre des Affaires Etrangeres des Pays. Bas et CIRAD/PRIFAS (France). 83 pp.

Leonide, J. \& Leonide, J.C. 1977. Contribution XI. Bio-taxonomie de Blaesoxipha litoralis, Villeneuve 1911 (Diptera, Sarchophagidae). - Annales de la Societe Entomologique de France. 13 (2): 297-313.

Lipa, J.J. \& Desco, K.V. 1988. Occurence of protozoan infections in Calliptamus italicus, L. (Ortoptera: Acridae), Lobesia botrana, Schiff (Lepidopthera: Tortricidae) and Carpicapsa pomonella, L. (Lepidoptera: Totricidae) in Italy. Prace Naukowe Instytut Ochrony Roslin (Poznan.) 29 (2): 43-46.

Lomer, C.J. \& Prior, C. (eds) 1992. Biological control of locusts and grasshoppers. $\mathrm{C} \cdot \mathrm{A} \cdot \mathrm{B}$ International, Oxon. $394 \mathrm{pp}$.

Macek, K.J. \& McAllister, W.A. 1970. Insecticide susceptibility of some common fish family representatives. - Trans. Amer. Fish Soc. 99(1):20-27.

Matthews, G.A. 1977. C.d.a.-controlled droplet application.- PANS 23 (4): 387- 394.

Merton, L.F. 1959. Studies on the ecolgy of the Moroccan locust (Dociostaurus maroccanus) in Cyprus. - Anti-locust Bull. no. 34: 123 pp. 
Merton, L.F. 1961. The Moroccan locust (Dociostaurus marroccanus, Thunb.) in Iran. - Anti-locust Bull. no. 37: 66 pp.

Milner, R.J. 1992. Selection and characterization of strain of Metarhizium anisopliae for control of soil insects in Australia. - In; Lomer, C.J. \& Prior, C. (eds), Biological control of locusts and grasshoppers. C.A.B International, Oxon. pp. 200-208.

Odhiambo, T.R. 1988. Health, environmental and economic impact of Desert locust and recent control campaigns in Asia, Africa and the Arab States. - Proceeding at UNDP-meeting. Cairo. 27 pp.

Ottesen, P.S. \& Sømme, L. 1987. Environmental effects of insecticides against grasshoppers and locusts. - Report to the Royal Norwegian Ministry for Development Cooperation. 44 pp.

Ottesen, P.S., Fossland, S., Johannesen, B. \& Simonsen, J. H. 1989. Reduced rates of fenitrothion: the effect on Oedaleus senegalensis (Orthoptera) and non-target organisms in Mali, West Africa. - Report to the Royal Norwegian Ministry for Development Coopereation. 24 pp.

Ottesen, P.S. \& Sømme, L. 1990. The impact of three pesticides, fenitrothion, lambdacyhalothrine and teflubenzurone, on grasshoppers and non-target organisms in Mali, West Africa. Report to the Royal Norwegian Ministry for Development Cooperation. 42 pp.

Ottesen, P.S., Butrous, M.G., Fossland, S. \& Johannesen, B. 1990. The impact of three pesticides, fenitrothion, deltamethrine and lambdacyhalothrine, in low dosages on the Sahelian tree locust Anacridium m. melanorhodon in Sudan, including evaluations of cost savings. - Report to the Royal Norwegian Ministry of Foreign Affairs. 24 pp.

Paludan, K. 1959. On the birds of Afghanistan. - Vidensk. Medd. Dansk naturh. For., Vol. 122. 322 pp.

Papillon, M. 1960. Etude prèliminaire de la rèppercucussion du groupement des parents sur les larves nouveau-nèes de Schistocerca gregaria. - Forsk, Bull. biol, 93: 203-63.

Pastre, P., Smolikowski, S, and Thewys, G. 1989. Locust and grasshoppers control: Deltamethrin file. - Roussel Uclaf, Division Agrovet, Paris. 127 pp.

Peterson, R.T., Mountfort, G. \& Hollom, P.A.D. 1972. Europas fugler. - Tiden. Oslo. $386 \mathrm{pp}$.

Pichler, F. 1956. Zur postembryonalen Entwicklung der Feldheuchchrecken. - Zool. Anz. 6: 513-31. 
Postel, S. 1987. Defusing the toxics threat: Controlling pesticides and industrial waste. - Worldwatch Paper 79.

Purrini, K. \& Rohde, M. 1988. Light and electron microscopical studies on two new diseases in natural populations of the Desert locust Schistocerca gregaria and the grassland locust Chortipes sp., caused by two entomopoxviruses. - J. Invert. Pathol. 51: 281-283.

Roberts, T.J. 1991. The birds of Pakistan. Volume 1. - Oxford University Press, Karachi. 598 pp.

The Royal Society of Chemistry 1990. The agrochemicals handbook, second edition. Royal Society of Chemistry, Information Service, Cambridge.

The Royal Society of Chemistry 1991. European directory of agrochemical products. Volume 3: Insecticides, acaricides \& nematicides. - Cambridge. 622 pp.

Schanke, T. 1992. Angående data om deltametrin og lindan - Letter 20.2.92 from Landbruksdepartementets Giftnemd to author. Ark.nr.832.0. 2 pp.

Sikka, H.L. \& Singh, D.P. 1987. Breeding opportunities for the Desert locust, Schistocerca gregaria in Afghanistan. - Indian Journal of Entomology, 49 (4): 520-531.

Sondbø, S. \& Ottesen, P. 1991. Birdobservations - Badakshan, Afghanistan \& NFWP, Pakistan. Unpublished, in prep. for The Sandgrouse. 32 pp.

Steedman, A. (ed.) 1988. Locust handbook. Second edition. - Overseas development Natural Resources Institute, London. 180 pp.

Stover, W.J. \& Greathead, D.J. 1969. Numerical changes in a population of the Desert locust with special refernce to the factors responsible for mortality. - J. appl. Ecol. 6, 203-235.

The Swedish Committee for Afghanistan 1990 a. Agricultural Survey of Afghanistan. Northern Afghanistan Crop Protection Program. 7 th report. 55 pp.

The Swedish Committee for Afghanistan 1990 b. Agricultural Survey of Afghanistan. Northern Afghanistan insect damage survey, 8 th report. $47 \mathrm{pp}$.

The Swedish Committee for Afghanistan 1990 c. Agricultural Survey of Afghanistan. Northern Afghanistan food deficit survey. 9 th report. 33 pp.

Symmons, P. 1991. Controlling desert locusts. - FAO. 53 pp.

Tero Safe A/S 1989. Safechem. - Database for MS-DOS operated PC. Horten. 
Tsegaye, B., Sabuni, F., Serenje, W., Lund, O. \& Jayaaseela, F. 1990. The locust problem, in search of new management approaches. - Paper presented at the MN1 course of the MNRSA programme, Noragric, Ás. Unpublished, 48 pp.

Tystad, J. 1992. Farlig stoff ikke forbudt, - Dagbladet (Oslo), 20 Januray 1992.

UNEP 1987. State of the world environment. - Nairobi, 76 pp.

UNEP 1989. Hexaclorocyclohexans. - IRPTC Bulletin, 9 (2): 23 - 24.

Uvarov, B.P. 1921. A revision of the genus Locusta, L. (=Pachytylus, Fieb.) with a new theory as to the periodicity and migrations of locusts. - Bull. ent. Res. $12: 135-63$.

Uvarov, B.P. 1928. Grasshoppers and locusts. - Imperial Bureau of Entomology, London.

Uvarov, B.P. 1931. Insects and climate. - Trans. Entomol. Soc. Lond. 79:1-247.

Uvarov, B.P. Ecological studies on the Moroccan locust in Western Anatolia. - Bull. ent. Res. 23: 273 - 287.

Uvarov, B.P. 1961. Quantity and quality in insect populations. - Proc. Roy. Entomol. Soc. Lond. 25:52-59.

Uvarov, B.P. 1966. Grasshopppers and locusts, vol. 1. - Cambridge Univ. Press, Cambridge. $481 \mathrm{pp}$.

Waloff, Z. 1976. Some temporal characteristics of Desert locusts plagues, - AntiLocust Mem. 13:1-36.

WHO 1990 a. Deltamethrin. - Environmental Health Criteria 97. Geneva.

WHO 1990 b. Lindane. - Environmental Health Criteria 124. Geneva.

WHO 1991. IARC monographs on the evaluation of carcinogenic risks to humans. -

Occupational exposures in insecticide application and some pesticides. Volume 53: 251-266.

Øhme, M. 1991. Dispersion and transport paths of toxic persistent organochlorines to the Artic - levels and consequences. - The Science of the Total Environment. 106: 43 53. 


\section{Appendix}

Raw data on locust counts

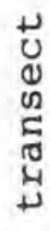

?ृ.

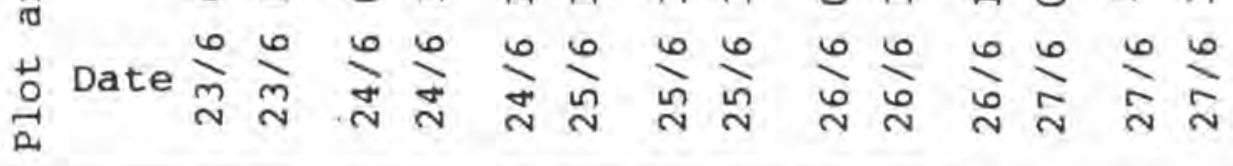

\begin{tabular}{l|lllllllllllll}
$1-1$ & 20 & 14 & 19 & 23 & 7 & 14 & 8 & 5 & 5 & 8 & 13 & 7 & 13
\end{tabular}

$\begin{array}{lllllllllllllll}1-3 & 33 & 32 & 33 & 29 & 34 & 27 & 3 & 4 & 9 & 10 & 13 & 15 & 27\end{array}$

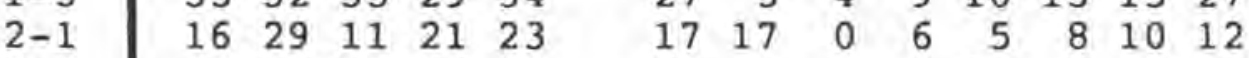

\begin{tabular}{l|lllllllllllll}
$2-2$ & 24 & 22 & 15 & 20 & 24 & 23 & 6 & 4 & 8 & 11 & 9 & 5 & 14
\end{tabular}

$\begin{array}{lllllllllllllll}2-3 & 32 & 26 & 16 & 24 & 27 & 25 & 14 & 6 & 8 & 12 & 13 & 13 & 12\end{array}$

$\begin{array}{lllllllllllllll}3-1 & 18 & 20 & 9 & 13 & 21 & & 28 & 12 & 2 & 17 & 12 & 10 & 19 & 8\end{array}$

$\begin{array}{llllllllllllll}3-2 & 35 & 31 & 24 & 22 & 32 & 36 & 27 & 6 & 33 & 12 & 9 & 13 & 11\end{array}$

$\begin{array}{llllllllllllllll}3-3 & 38 & 35 & 11 & 35 & 26 & & 36 & 32 & 14 & 17 & 15 & 9 & 13 & 25\end{array}$

\begin{tabular}{l|llllllllllll}
$4-1$ & 37 & 35 & 51 & 35 & 34 & 40 & 41 & 39 & 19 & 29 & 38 & 50
\end{tabular}

\begin{tabular}{l|llllllllllll}
$4-2$ & 36 & 22 & 25 & 27 & 28 & 31 & 32 & 26 & 25 & 15 & 27 & 22
\end{tabular}

\begin{tabular}{l|lllll}
$4-3$ & 21 & 5 & 5 & 13 & 16
\end{tabular}

$5-1$

$5-2$

$5-3$

$6-1$

$\begin{array}{lllll}35 & 34 & 31 & 33 & 27\end{array}$

28

$\begin{array}{llllll}22 & 27 & 10 & 17 & 19 & 28\end{array}$

$\begin{array}{lllll}30 & 28 & 9 & 6 & 8\end{array}$

32

$\begin{array}{lllllll}28 & 32 & 40 & 22 & 42 & 60\end{array}$

$\begin{array}{llllll}20 & 15 & 8 & 11 & 9 & 27\end{array}$

$\begin{array}{llllll}17 & 4 & 5 & 8 & 4 & 20\end{array}$

$6-2$

$\begin{array}{lllll}12 & 9 & 4 & 4 & 4\end{array}$

27

$\begin{array}{llllll}25 & 8 & 16 & 7 & 14 & 22\end{array}$

$6-3$

$\begin{array}{lllll}39 & 5 & 6 & 6 & 9\end{array}$

13

$\begin{array}{llllll}3 & 12 & 5 & 4 & 16 & 11\end{array}$

$7-1$ $\begin{array}{lllll}36 & 13 & 18 & 7 & 10\end{array}$

12

$\begin{array}{llllll}11 & 10 & 6 & 3 & 35 & 15\end{array}$

$\begin{array}{llllll}15 & 18 & 4 & 10 & 9 & 22\end{array}$

$7-2$

$7-3$

$8-1$

$8-2$

$8-3$

$9-1$

$9-2$

9-3

10-1

$10-2$

10-3

11-1

$11-2$

11-3

12-1

$\begin{array}{lllll}7 & 8 & 4 & 5 & 3\end{array}$

$\begin{array}{rrrrr}4 & 8 & 1 & 7 & 4 \\ 14 & 7 & 2 & 5 & 5\end{array}$

1
4
4

$\begin{array}{llllll}1 & 1 & 1 & 2 & 0 & 0\end{array}$

$\begin{array}{llllll}1 & 1 & 3 & 1 & 0 & 2 \\ 4 & 2 & 1 & 5 & 5 & 3\end{array}$

$12-2$

$12-3$

$\begin{array}{llll}0 & 0 & 0 & 0\end{array}$

13-1

$13-2$

$13-3$

$14-1$

$14-2$

$\begin{array}{llll}2 & 0 & 0 & 0\end{array}$

$\begin{array}{llll}6 & 1 & 0 & 2\end{array}$

$\begin{array}{llll}5 & 1 & 0 & 0\end{array}$

$\begin{array}{llll}1 & 0 & 0 & 0\end{array}$

$\begin{array}{llll}2 & 0 & 0 & 1\end{array}$

$\begin{array}{llll}2 & 2 & 0 & 2\end{array}$

$\begin{array}{llll}1 & 0 & 0 & 1 \\ 0 & 0 & 0 & 0\end{array}$

$\begin{array}{llll}0 & 1 & 1 & 0\end{array}$

$\begin{array}{rrrr}3 & 1 & 1 & 2 \\ 10 & 3 & 0 & 1\end{array}$

$\begin{array}{llll}2 & 1 & 2 & 4\end{array}$

$\begin{array}{llll}26 & 4 & 1 & 1\end{array}$

\begin{tabular}{r|rrrrr}
$14-2$ & 14 & 5 & 8 & 10 & 10 \\
$14-3$ & 14 & 3 & 5 & 12 & 4
\end{tabular}

$\begin{array}{llll}3 & 2 & 1 & 2\end{array}$

$\begin{array}{lllll}31 & 25 & 13 & 13 & 12\end{array}$

0
3
1
5
2
6

$\begin{array}{llllll}0 & 1 & 0 & 1 & 0 & 0\end{array}$

$\begin{array}{lllll}5 & 8 & 5 & 6\end{array}$

$\begin{array}{lllll}5 & 6 & 3 & 6 & 6\end{array}$

$\begin{array}{llllll}0 & 0 & 1 & 1 & 0 & 1 \\ 1 & 1 & 2 & 0 & 4 & 1 \\ 0 & 2 & 2 & 0 & 0 & 1 \\ 0 & 2 & 2 & 0 & 0 & 1 \\ 7 & 4 & 2 & 2 & 2 & 2\end{array}$ 


\section{Appendix}

Raw data on locust counts

U

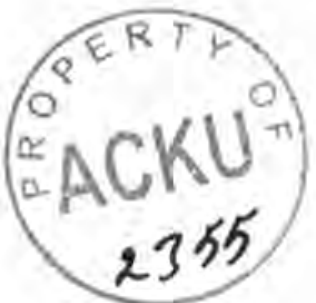

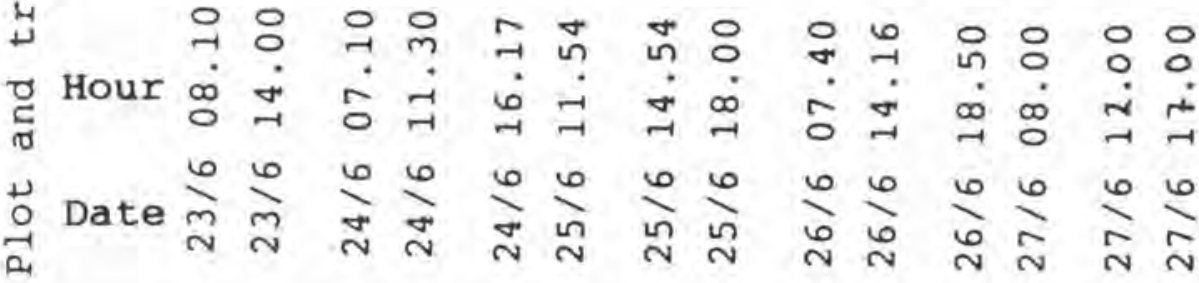

\begin{tabular}{|c|c|c|c|c|c|c|c|c|c|c|c|c|c|}
\hline $15-1$ & 14 & 17 & 14 & 14 & 10 & & 19 & 15 & 30 & 19 & 12 & 16 & 42 \\
\hline 15 & 24 & 16 & 11 & 18 & 21 & & 29 & 28 & 20 & 16 & 22 & 27 & 17 \\
\hline $15-3$ & 25 & 22 & 19 & 7 & 6 & & 19 & 14 & 21 & 20 & 9 & 22 & 35 \\
\hline $16-1$ & 5 & 6 & 3 & 13 & 11 & & 15 & 5 & 4 & 12 & 8 & 8 & 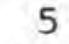 \\
\hline $16-2$ & 32 & 33 & 10 & 16 & 10 & & 34 & 14 & 18 & 9 & 9 & 25 & 11 \\
\hline $16-3$ & 36 & 22 & 15 & 25 & 24 & & 33 & 26 & 20 & 21 & 10 & 14 & 35 \\
\hline $17-1$ & 11 & 14 & 14 & 16 & 16 & & 14 & 20 & 19 & 15 & 10 & 10 & 21 \\
\hline $17-2$ & 33 & 19 & 8 & 22 & 11 & & 31 & 17 & 13 & 19 & 12 & 7 & 7 \\
\hline $17-3$ & 29 & 30 & 26 & 23 & 25 & & 48 & 29 & 25 & 20 & 14 & 26 & 32 \\
\hline $18-$ & 12 & 16 & 6 & 9 & 5 & 2 & 0 & 0 & 4 & 2 & 5 & 6 & 7 \\
\hline 18 & 22 & 23 & 23 & 24 & 14 & 0 & 2 & ? & 2 & 4 & 6 & 3 & 2 \\
\hline 18 & 37 & 26 & 22 & 23 & 20 & 11 & 2 & 0 & 7 & 7 & 9 & 12 & 8 \\
\hline 1. & 7 & 9 & 11 & 10 & 12 & 0 & 0 & 0 & 3 & 2 & 2 & 6 & 2 \\
\hline $19-$ & 23 & 21 & 31 & 21 & 21 & 2 & 0 & 1 & 4 & 1 & 0 & 1 & 7 \\
\hline 19 & 25 & 18 & 16 & 16 & 17 & 1 & 1 & 0 & 1 & 1 & 0 & 2 & 5 \\
\hline 20 & 11 & 22 & 17 & 11 & 9 & 1 & 1 & 1 & 2 & 3 & 6 & 4 & 12 \\
\hline $20-$ & 19 & 14 & 34 & 22 & 15 & 1 & 0 & 1 & 3 & 0 & 1 & 1 & 6 \\
\hline 20 & 18 & 15 & 7 & 15 & 13 & 1 & 2 & 1 & 3 & 1 & 3 & 2 & 3 \\
\hline 21. & 18 & 18 & 11 & 12 & 4 & & 20 & 22 & 16 & 15 & 15 & 18 & 24 \\
\hline $21-$ & 26 & 23 & 23 & 28 & 21 & & 31 & 25 & 24 & 30 & 36 & 32 & 38 \\
\hline 21. & 24 & 19 & 15 & 20 & 12 & & 28 & 34 & 22 & 15 & 6 & 21 & 27 \\
\hline $22-1$ & 26 & 17 & 10 & 16 & 10 & & 25 & 28 & 23 & 18 & 25 & 29 & 37 \\
\hline $22-2$ & 5 & 4 & 2 & 8 & 10 & & 9 & 7 & 20 & 6 & 9 & 12 & 13 \\
\hline $22-3$ & 9 & 5 & 2 & 8 & 9 & & 18 & 13 & 19 & 10 & 24 & 16 & 26 \\
\hline $23-$ & 18 & 20 & 6 & 14 & 6 & & 5 & 9 & 11 & 7 & 5 & 14 & 10 \\
\hline $24-$ & 11 & 7 & 2 & 9 & 4 & & 7 & 7 & 7 & 18 & 15 & 20 & 12 \\
\hline 24 & 16 & 12 & 11 & 25 & 15 & & 20 & 12 & 15 & 14 & 12 & 17 & 15 \\
\hline 24 & 5 & 8 & 3 & 9 & 5 & & 10 & 7 & 4 & 5 & 7 & 5 & 0 \\
\hline 25 & 40 & 25 & 21 & 17 & 8 & & 23 & 30 & 36 & 12 & 12 & 37 & 40 \\
\hline 2 & 40 & 17 & 11 & 22 & 15 & & 16 & 18 & 13 & 17 & 21 & 35 & 29 \\
\hline $25-3$ & 20 & 15 & 5 & 9 & 6 & & 14 & 10 & 18 & 14 & 8 & 15 & 18 \\
\hline $26-1$ & 8 & 16 & 4 & 7 & 3 & & 6 & 18 & 19 & 10 & 10 & 22 & 23 \\
\hline $26-2$ & 40 & 31 & 10 & 17 & 15 & & 29 & 14 & 13 & 8 & 37 & 23 & 30 \\
\hline $26-3$ & 13 & 17 & 11 & 14 & 10 & & 19 & 9 & 7 & 12 & 8 & 24 & 12 \\
\hline $27-1$ & 17 & 17 & 6 & 8 & 1 & & 0 & 0 & 1 & 0 & 2 & 5 & 1 \\
\hline $27-2$ & 35 & 27 & 20 & 24 & 20 & & 0 & 0 & 2 & 0 & 3 & 0 & 2 \\
\hline $27-3$ & 19 & 22 & 8 & 12 & 9 & & 1 & 0 & 0 & 0 & 1 & 1 & 2 \\
\hline $28-1$ & 37 & 38 & 25 & 25 & 36 & & 1 & 0 & 2 & 1 & 4 & 1 & 2 \\
\hline $28-2$ & 19 & 26 & 8 & 11 & 10 & & 0 & 0 & 2 & 0 & 2 & 1 & 0 \\
\hline $28-3$ & 48 & 24 & 14 & 12 & 9 & & 1 & 1 & 2 & 1 & 0 & 1 & 10 \\
\hline $29-1$ & 38 & 27 & 28 & 22 & 37 & & 1 & 0 & 0 & 0 & 1 & 5 & 2 \\
\hline $29-2$ & 43 & 25 & 14 & 8 & 17 & & 0 & 0 & 2 & 2 & 0 & 2 & 0 \\
\hline $29-3$ & 44 & 17 & 5 & 8 & 13 & & 1 & 0 & 1 & 0 & 0 & 2 & \\
\hline
\end{tabular}


